\title{
SELEÇÃO PARA ALTO TEOR DE ÓLEO NA SEMENTE DE MILHO E SEUS EFEITOS SOBRE CARACTERES AGRONÔMICOS
}

\author{
HERMES ARAMENDIZ TATIS
}

Orientador: Prof.Dr. Gera1do Antonio Tose11o

Tese apresentada à Escola Superior de Agricultura "Luiz de Queircz", da Universidade de São Paulo, para obtenção do tîtulo de Doutor em Agronomia, Ârea de Concentração: Genética e Melhoramento de Plantas

\author{
PIRACICABA \\ Estado de São Paulo - Brasil \\ JUNHO - 1990
}


Ficha catalográfica preparada pela Seção de Livros da Divisão de Biblioteca e Documentação - PCAP/USP

Aramendiz Tatis, Hermes

A661s Seleção para alto teor de óleo na semente de mitho e seus efeitos sobre caracteres agronômicos. Piracicaba, 1990.

$118 p$.

Tese - ESALQ

Bibliografia.

1. Milho - Semente - Teor de óleo 2. Semente Teor de óleo - Seleção I. Escola Superior de Agricultura Luiz de Queiroz, Piracicaba. 
SELEÇÃO PARA ALTO TEOR DE ÓLEO NA SEMENTE DE MILHO E SEUS EFEITOS SOBRE CARACTERES AGRONÔMICOS

HERMES ARAMENDIZ TATIS

Aprovado em: $07 / 08 / 90$

Comissão Julgadora:

Prof.Dr. Geraldo Antonio Tose11o

ESALQ/USP

Prof.Dr. João Rubens Zinsly

ESALQ/USP

Prof.Dr. Natal Antonio Vello

ESALQ/USP

Prof.Dr. Antonio Luiz Fancel1i

ESALQ/USP

Prof.Dr. Norberto da Silva

FCA/UNESP

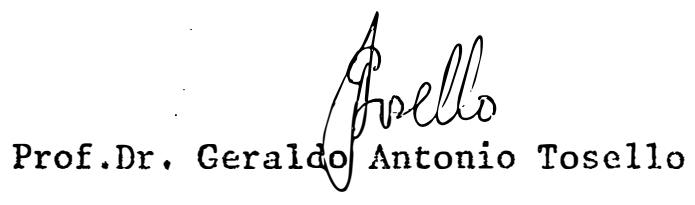

Orientador 
A minha esposa Trinidad e aos meus filhos Heidy e José Jorge. 
AGRADECIMENTOS

- Ao Prof. Dr. Geraldo Antonio Tose11o, pela orientação e amizade;

- Ao Prof.Dr. Cláudio Lopes de Souza Junior, pela amizade e sugestões apresentadas;

- Aos Instituto Colombiano Agropecuário - ICA, nas pessoas dos Doutores Ange1 Mendoza 01ive1la e Pablo Buritica e Departamento de Genética da ESALQ/USP, que possibilitaram a minha participação no cur so de Pós-Graduação;

- A FINEP, que auxiliou no financiamento da pesquisa e construçao do NMR;

- Ao grupo de Ressonância Nuclar Magnética da EMBRAPAUAPDIA de São Carlos, que trabalhăn na construção do NMR.

- Ao Dr. Luis Alberto Colnago, da EMBRAPA-UAPDIA de São Carlos, pela colaboração nas anālises de ressonância nuclear magnética;

- Aos docentes do Departamento de Genética pelos ensinamentos sobre värios aspectos do trabalho;

- Ãs Bibliotecárias, Sras. Nilce T. Puga, Rosmary dos Santos e Terezinha J.L. Barrete, pela colaboração e amizade;

- Aos funcionârios Antonio Desiderio, Juscelino Desiderio, Marcos A. Gorga e José Carmezini de Paula, por sua colaboração na execução dos trabalhos de campo e laboratório. 
INDICE

Página

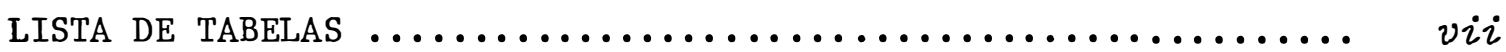

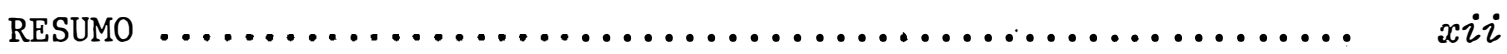

SUMMARY

1. INTRODUÇÃo $\ldots \ldots \ldots \ldots \ldots \ldots \ldots \ldots \ldots \ldots \ldots \ldots \ldots \ldots \ldots \ldots \ldots \ldots \ldots \ldots \ldots \ldots$

2. REVISÃO DE LITERATURA $\ldots \ldots \ldots \ldots \ldots \ldots \ldots \ldots \ldots \ldots \ldots \ldots \ldots \ldots$

2.1. Composição e Controle Genético do Óleo de Milho ....... 4

2.2. Fatores que Afetam o Conteüdo de óleo em Milho ........ 6

2.3. Efeitos da Seleção para Teor de óleo e suas Alte-

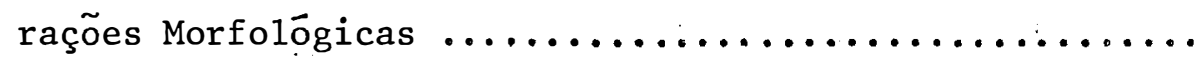
1 4 4

6

2.4. Correlações Entre o Teor de óleo e Caracteres da

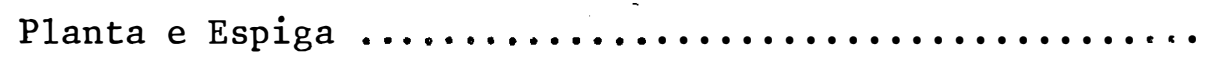

2.5. Ressonância Magnética Nuclear (NMR) na determinação do conteúdo de óleo e Sua Relação com Métodos

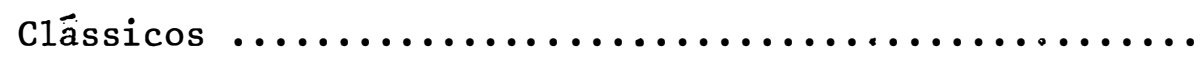

3. MATERIAL E MÉTODOS $\ldots \ldots \ldots \ldots \ldots \ldots \ldots \ldots \ldots \ldots \ldots \ldots \ldots \ldots \ldots$

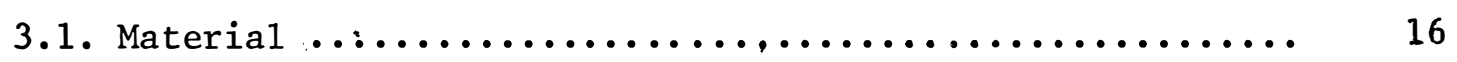

3.2. Métodos $\ldots \ldots \ldots \ldots \ldots \ldots \ldots \ldots \ldots \ldots \ldots \ldots \ldots \ldots . \ldots \ldots \ldots$

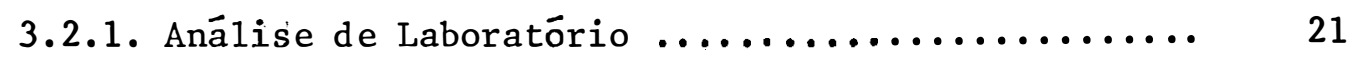

3.2.2. Estimativas de parâmetros estatísticos e

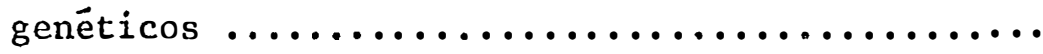

3.2.3. Análise de variância $\ldots \ldots \ldots \ldots \ldots \ldots \ldots \ldots \ldots$

3.2.4. Obtenção das estimativas dos ganhos genéticos e respostas correlacionadas com a seleção .......

3.2.5. Determinação da precisão das estimativas obti-

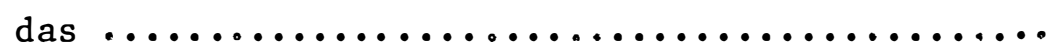


Página

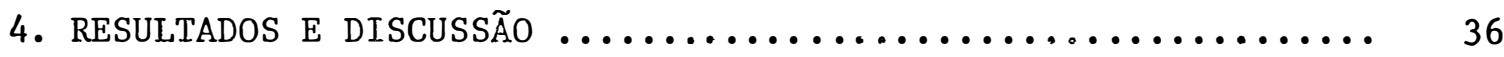

4.1. Médias populacionais e Análise de Variância .......... 36

4.2. Estimativas dos Parâmetros Genéticos e Fenotỉpicos ..... 52

4.2.1. Estimativas para os caracteres: altura da planta e altura da espiga ................ 52

4.2.2. Estimativas para o carāter rendimento ......... 54

4.2.3. Estimativas para o carāter diâmetro da espiga .... 56

4.2.4. Estimativas para o carāter comprimento da espiga ............................. 58

4.2.5. Estimativas para os caracteres: número de fileiras e nümero de grãos por fileira .......... 59

4.2.6. Estimativas para os caracteres: comprimento de grãos e largura de grãos ................ 62

4.2.7. Estimativas para os caracteres: peso de 100

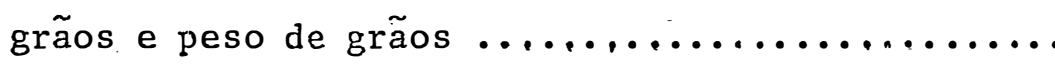

4.2.8. Estimativas para os caracteres: diâmetro do sabugo e peso do sabugo ................... 66

4.2.9. Estimativas para os caracteres: densidade dos grãos e porcentagem de öleo ................ 68

4.3. Estimativas das Correlações Genéticas e Fenotỉpicas .... 72

4.3.1. Correlações entre a porcentagem de óleo e os caracteres altura da planta, altura da espiga, comprimento de grãos, largura de grãos e rendimento $\ldots \ldots \ldots \ldots \ldots \ldots \ldots \ldots \ldots \ldots \ldots$.

4.3.2. Correlações entre a porcentagem de óleo e os caracteres comprimento da espiga, diâmetro da espiga, número de fileiras e número de

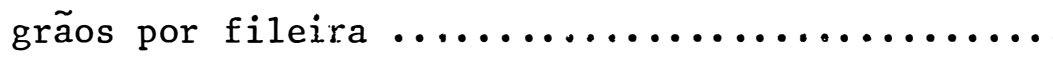


4.3.3. Correlações entre a porcentagem de óleo e os caracteres peso de grãos, peso de 100 grãos, densidade dos grãos, diâmetro e peso do sabudo ..... 76

4.4. Respostas Correlacionadas Esperadas com Seleção .......... 78

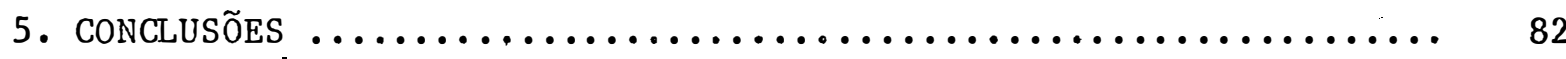

REFERÊNCIAS BIBLIOGRĀFICAS $\ldots \ldots \ldots \ldots \ldots \ldots \ldots \ldots \ldots \ldots \ldots \ldots \ldots \ldots \ldots \ldots \ldots \ldots$

TABELAS DE RESULTADOS $\ldots \ldots \ldots \ldots \ldots \ldots \ldots \ldots \ldots \ldots \ldots \ldots \ldots \ldots \ldots, 10 \ldots \ldots$ 
LISTA DE TABELAS

Tabela no

Pāgina

1 Esperança matemātica dos quadrados médios E(QM), obtidos nas análises de variância segundo o delineamento blocos ao acaso, para os diversos caracteres estudados, ao nível de médias de parcelas e ao nível de plan tas individuais

2 Esperança matemática dos produtos médios obtidos nas anālises de covariância segundo o delineamento blocos ao acaso, para os diversos caracteres estudados, ao ní vel de médias de parcelas e ao nível de plantas individuais

3 Estimativas de médias, com os respectivos intervalos de confiança, de quinze caracteres das populações Piranão VD-2-MI origina1 e Piranão VD-2-MI-AO. Piracica

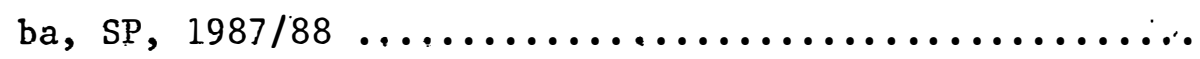

4 Estimativas de médias, com os respectivos intervalos de confiança de quinze caracteres das populações Piranão VF-1-MI-original e Piranão VF-1-MI-A0, Piracicaba, SP, $1987 / 88$

5 Valores e significâncias dos quadrados médios obtidos ao nível de médias de parcelas de quinze caracteres das populações Piranão VD-2-MI original e Piranão VD2-MI-AO, Piracicaba, SP, $1987 / 88$.................. 104 
6 Valores e significâncias dos quadrados mẻdios obtidos ao nîvel de médias de parcelas, de quinze caracteres das populações Piranão VF-1-MI-original e Piranão VF-1-MI-AO. Piracicaba, SP, $1987 / 88 \ldots \ldots \ldots \ldots \ldots \ldots \ldots$

7 Estimativas de variâncias genéticas ambientais e fenotîpicas, com os respectivos desvios padrões do rendimento, em (g/planta $)^{2}$ das populações Piranão VD2-MI origina1, Piranão VD-2-MI-AO, Piranão VF-1-MI original e Piranão VF-1-MI-AO. Piracicaba, SP, 1987/88 .. 106

8 Estimativas de variâncias genēticas ambientais e fenotîpicas, com os respectivos desvios padrões de quatorze caracteres da população Piranão VD-2-MI original.

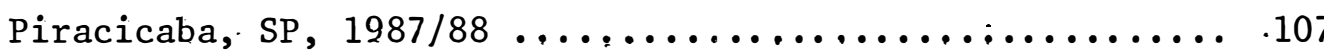

9 Estimativas de variâncias genéticas ambientais e fenotípicas, com os respectivos desvios padrões de quatorze caracteres da população Piranão VD-2-MI-AO. Pira-

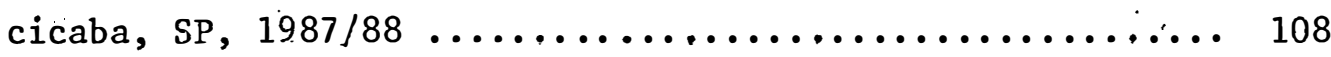

10 Estimativas de variâncias genéticas ambientais e feno tîpicas, com os respectivos desvios padrões de quatorze caracteres da população Piranão VF-1-MI original. Piracicaba, SP, $1987 / 88$....................... 109

11 Estimativas de variâncias genéticas ambientais e feno tí.picas, com os respectivos desvios padrões de quatorze caracteres da população Piranão VF-1-MI-AO. Piracicaba, SP, $1987 / 88$ 
12 Estimativas de coeficientes de herdabilidade, coeficientes de variação genética e experimental e coeficiente $b$, relativas a quinze caracteres das populações Piranão VD-2-MI original e Piranão VD-2-MI-AO. Pira-

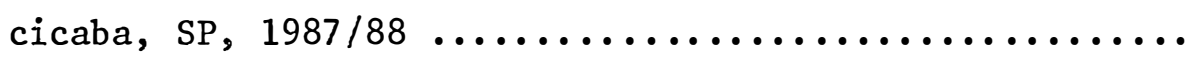

13 Estimativas de coeficientes de herdabilidade, coeficientes de variação genética e experimental e coeficiente b, relativas a quinze caracteres das populações Piranão VF-1-MI original e Piranão VF-1-MI-AO. Piracicaba, SP, 1987/88

14 Ganhos genéticos esperados por ciclo de seleção, em porcentagem das médias de cinco caracteres das populações Piranão VD-2-MI original e Piranão VD-2-MI-AO quando aplicada a intensidade de seleção de $10 \%$ entre progênies, Piracicaba, SP, 1987/88

15 Ganhos genéticos esperados por ciclo de seleção, em * porcentagem das médias de cinco caracteres das populações Piranão VF-1-MI original e Piranão VF-1-MI-AO, quando aplicada a intensidade de seleção de $10 \%$ entre

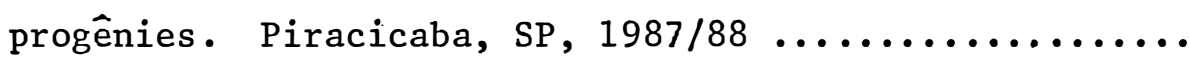

16 Ganhos genéticos esperados por ciclo de seleção, em porcentagem das médias de dez caracteres da populações Piranão VD-2-MI original e Piranão VD-2-MI-AO. Pira-

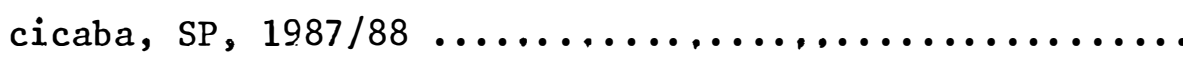


17 Ganhos genêticos esperados por ciclo de seleção, em porcentagem das médias de dez caracteres das popula-

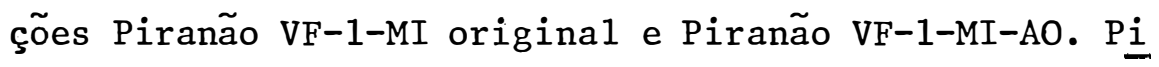
racicaba, SP, $1987 / 88$

18 Estimativas de covariâncias genéticas ambientais e fe notípicas, entre o carāter porcentagem de óleo e quatorze caracteres da população Piranão VD-2-MI origina1. Piracicaba, SP, $1987 / 88$......................

19 Estimativas de covariâncias genēticas ambientais e fenotîpicas entre o caráter porcentagem de óleo e quatorze caracteres da população Piranão VD-2-MI-AO. Piracicaba, SP, $1987 / 88$

20 Estimativas de covariâncias genéticas ambientais e fe notípicas, entre o carāter porcentagem de óleo e quatorze caracteres da população Piranão VF-1-MI original. Piracicaba, SP, $1987 / 88$

21 Estimativas de covariâncias genéticas ambientais e fe notípicas, entre o carāter porcentagem de óleo e quatorze caracteres da população Piranão VF-1-MI-AO. Piracicaba, SP, $1987 / 88$

22 Estimativas dos coeficientes de correlação entre o caráter porcentagem de óleo e cinco caracteres das populações Piranão VD-2-MI-original e Piranão VD-2-MI-AO. Piracicaba, SP, $1987 / 88$....................... 
23 Estimativas dos coeficientes de correlação entre o caráter porcentagem de óleo e cinco caracteres das populações Piranão VF-1-MI-original e Piranão VF-I-MI-AO.

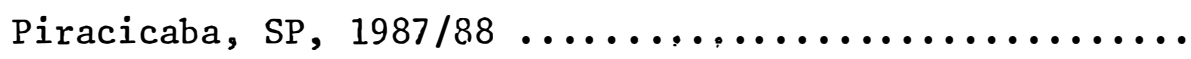

24 Estimativas dos coeficientes de correlação entre o carâter porcentagem de óleo e nove caracteres das populações Piranão VD-2-MI-original e Piranão VD-2-MI-AO.

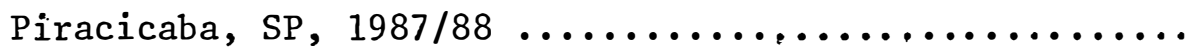

25 Estimativas dos coeficientes de correlação entre o carāter porcentagem de óleo e nove caracteres das populações Piranão VF-1-MI-original e Piranão VF-1-MI-AO. Piracicaba, SP, 1987/88

26 Estimativas das respostas correlacionadas com a seleção para teor de ōleo, em porcentagem das médias de quatorze caracteres das populações Piranão VD-2-MI-orí ginal e Piranão VD-2-MI-AO. Piracicaba, SP, 1987/88 ....

27 Estimativas das respostas correlacionadas com a seleção para teor de óleo, em porcentagem das médias de quatorze caracteres das populações Piranão VF-1-MI-ori ginal e Piranão VF-1-MI-AO. Piracicaba, SP, 1987/88 ... 
SELEÇÃO PARA ALTO TEOR DE ÓLEO NA SEMENTE DE MILHO E SEUS EFEITOS SOBRE CARACTERES AGRONÔMICOS

Autor: Hermes Aramendiz Tatis Orientador: Prof.Dr. Geraldo Antonio Tose11o

RESUMO

$\mathrm{Na}$ presente pesquisa foi feita uma avaliação das populações originais Piranão VD-2-MI-0 e Piranão VF-1-MI-0 e seu terceiro ciclo de seleção recorrente intrapopulacional para alta porcentagem de óleo na semente de milho, Piranão VD-2-MI-AO e Piranão VF-1-MI-AO; com o objetivo principal de verificar os efeitos da seleção para alto teor de óleo sobre caracteres agronômicos.

Foram utilizadas 100 progênies de meios irmãos de cada uma das populações, as quais foram avaliadas em 1ātices $10 \times 10$ com três repetições durante o ano agrícola 1987/1988, em Piracicaba - São Paulo. Foram tomados dados de altura de planta, altura de espiga, rendimento, diầmetro da espiga, comprimento da espiga, nümero de fileiras, nümero de grãos por fileira, comprimento de grãos, largura de grãos, peso de 100 grãos, peso de grãos, diâmetro do sabugo, peso do sabugo, densidade dos grãos e porcentagem de ōleo na semente.

Os resultados obtidos revelam que a seleção recorrente, foi efetiva para elevar a porcentagem de óleo na semente de milho, 
principalmente na população Piranão VD-2-MI-A0, que registrou um aumento de $21,21 \%$ em relação à população original, enquanto que no Piranão VF-1-MI-A0 o aumento foi $13,42 \%$ em relação ao Piranão VF-1-MI-0. Não obstante, as populações com grãos tipo flint apresentaram maior porcentagem de ōleo que as populações com grãos tipo dentado.

A seleção para maior porcentagem de óleo, levou a modificações divergentes nas médias de caracteres como altura da planta, altura da espiga, comprimento da espiga, diâmetro da espiga, número de grãos por fileira, comprimento de grãos, largura de grãos, peso de grãos e peso de 100 grãos. Entretanto, respostas no mesmo sentido foram registradas para o número de fileiras, diâmetro do sabugo, peso do sabugo e densidade dos grãos.

A população Piranão VF-1-MI-AO apresentou maior magnitude nas estimativas da variância genêtica aditiva em relação à população Piranão VD-2-MI-AO, para caracteres como alturá da planta, altura da eșịiga, número de grãos por filleira, peso de 100 grãos e peso de grãos e uma notável redução deste parâmetro para a porcentagem de óleo.

'A exceção do caráter peso de grãos na população Piranão VD-2-MI-0, a densidade dos grãos foi a característica que registrou os valores mais baixos de herdabilidade para as quatro populações, tanto ao nível de planta como ao nível de médias. As outras características registraram valores médios, sendo a herdabilidade da porcentagem de óleo de maior magnitude para as populações com grãos do tipo dentado do que f́lint.

As estimativas das correlações genéticas aditivas entre a porcentagem de óleo na semente e as demais características em estudo 
foram em termos gerais divergentes com tendência negativa para Piranão VF-1-MI-AO e positiva para Piranão VD-2-MI-AO. Pela proximidade de seus valores a zero, as associações entre a porcentagem de óleo e os caracteres diâmetro do sabugo e peso do sabugo, das populações Piranão VF-1-MI-0 e Piranão VF-1-MI-A0, estes indicam que o teor de óleo pode ser melhorado sem afetar estas características. Nas populações com grãos do tipo dentado, o valor próximo a zero para a correlação entre o teor de óleo e peso do sa bugo, não foi constante e mudou possivelmente pela quebra de 1igações entre genes favoráveis e não favorāveis para alto teor de óleo na semente.

As estimativas dos progressos genéticos esperados com os processos de seleção entre famílias de meios irmãos e, entre e dentro de famílias de meios irmãos indicam que pode-se esperar alterações significativas para caracteres como rendimento, altura da planta, altura da espiga, peso de 100 grãos, diâmetro do sabugo, peso do sabugo e porcentagem de ōleo, sendo os ganhos deste $\bar{u} 1$ timo carāter de maior magnitude para as populações dentado e praticamente nenhuma alteração para a densidade dos grãos.

As respostas correlacionadas indicam que a seleção para aumentar o teor de óleo nos grãos no Piranão VF-1-MI-AO, poderá causar redução na maioria dos caracteres, principalmente peso de 100 grãos, peso de grãos, comprimento de grãos e rendimento e pouca redução na densidade dos grãos, peso do sabugo e diâmetro do sabugo. Para o Piranão VD-2-MI-AO poderá causar redução na largura de grãos e nümero de grãos por fileira e pouca alteração para a altura da planta e altura da espiga. 
SELECTION FOR HIGH OIL CONTENT IN THE MAIZE KERNEL AND ITS EFFECTS

ON AGRONOMIC TRAITS

Author: Hermes Aramendiz Tatis Adviser: Prof.Dr. Geraldo Antonio Tosel1o

SUMMARY

The present research was done in order to evaluate the third cycle of recurrent selection for high oil content and to measure the main effects of this selection on several agronomic traits. Four maize .populations were used, the Piranão VD-2-HS original and Piranão VF-1-HS original, and the derivatives for higher oil content Piranão VD-2-HS high oil and Piranão VF-1-HS high oil.

One hundred half-sib progenies from each population was planted in Piracicaba (Caterpillar)-SP in 1987/88, using a . $10 \times 10$ lattice design with three replications. Data were colected for plant and ear height, yield, diameter and ear length, number of kernel per row, number of row kernel, kernel length and width, 100 kernel weight, kernel weight, cob diameter and weight, kernel density and oil content in the kernel.

The results are indicative that the selection was effective and increased the oil content in both populations, $21,21 \%$ in the Piranão VD-2-HS-HO and $13,42 \%$ in the Piranão VF-1-HS-HO, when compared to the original. Both flint populations have a higher oil content than the dent 
counterpart. Under this selection pressure some traits presented a divergent change in the direction of average response, as plant and : ear height, ear length, ear diameter, number of kernels per row, kernel width, kernel weight and 100 kernel weight. However, changes in the same direction were detected for row number, cob diameter, cob weight and kernel density.

Compared to the Piranão VD-2-HS-HO, the Piranão VF-1-HS-HO had a higher additive genetic variance for plant and ear height, number of kernel per row, 100 kernel weight and kernel weight, and a lower additive value for oil content.

Excluding kernel weight in the Piranão VD-2-HS original, kernel density had the lower heritability value among the four populations in both levels (plant and mean). Other traits were in the meadle class values and the higher heritability value was detected for oil content in the dent populations.

The estimates of additive genetic correlation between the oil content and the other traits were in general divergent in direction and mostly negative for the Piranão VF-1-HS-HO and positive for the Piranão VD-2-HS-HO. Correlations near zero like oil content by cob diameter and cob weight in the flint populations, implies that no effects will be detected in both directions. The same is not true when the dent population is analyzed, since there is a change in direction for the association oil content by cob weight, probably because of the breakage within the linkage genes associated or not with the oil content in the seeds. 
The estimates of indirect expected genetic progress with selection among and within half-sib families allow the conclusion that some progress will be achieved for yielding, plant and ear height, 100 kernel weight, cob diameter, cob weight and oil content. A higher progress for oil is expected within the dent population; no progress is expected for kernel density in both populations.

Correlated response are indicative that selection for oil content in the Piranão VF-1-HS-HO may cause some reduction in most of the traits, mainly in 100 kernel weight, kernel length, yield and very little for cob weight and cob diameter. Within the Piranão VD-2-HS-HO there will be some reduction for kernel width, and number of kernel per row and very little for plant and ear height. 


\section{INTRODUÇÃO}

E de amplo conhecimento a importância que representa o óleo de milho na preservação da saúde humana, pois os teores baixos de ácidos graxos não saturados é uma garantia na qualidade nutricional de seus produtos industriais, possibilitando baixos níveis do conteúdo de colesterol no sangue; o que minimiza os problemas cardiovasculares e hipertensao (FITCH, 1985).

A qualidade do óleo de milho está determinada pelas altas e baixas porcentagens de ácido linoléico e linolênico. A ausêncịa de valores significativos de äcido linolênico determinam se este óleo pode ser armazenado sem apreciāvel deterioração pela presença de antioxidantes naturais.

Segundo JUGENHEIMER (1961), o óleo de milho pode ter utilidade tanto alimentícia como não alimentícia. Alimentîcia em produtos de padaria, óleo de cozinha, margarinas, maionese, tempero de saladas, etc. Os usos não alimentícios podem ser na fabricação de munição, químicos, cosméticos, esmaltes, sabão, óleo solūvel, etc. Além disso, determinados ácidos graxos insaturados são essenciais para o crescimento, 
gravidez, lactação, conservação normal da pele e funções do fígado e rim.

0 teor de óleo no grão de milho pode ser modificado através do melhoramento genético, com relativa facilidade, mediante um aproveitamento eficiente da variância aditiva, e também porque a anālise individual de sementes pelo método NMR (Ressonância Nuclear Magnética) facịlita o trabalho de seleção dentro da progênie, por não destruir a semente, permitindo identificar sementes de maior teor de óleo, o qual è impossỉvel conseguir mediante a aplicação dos métodos químicos, que são destrutivos e muito vagarosos no processo de determinação dos teores de óleo.

Vários trabalhos feitos por diferentes pesquisadores demonstraram a alteração da porcentagem de óleo, entre eles, WOODWORTH et alii (1952), que após 50 gerações de seleção massal divergente na variedade "Burr's White", modificaram de $4,7 \%$ para $15,36 \%$ e 1,01\%; SPRAGUE et alii (1952), através da aplicação de dois ciclos de seleção recorrente na variedade sintética "Stiff Stalk", aumentaram de 4,2\% para $7 \%$; MILLER et alii (1981) expressaram que, no cultivar "Reid Yellow Dent", sete ciclos de seleção praticados dentro de famîlias de meios-irmãos aumentaram o teor de óleo de 4,0\% para 9,1\%. Assim mesmo, DUDLEY et alii (1974) relataram que os aumentos na porcentagem de óleo, não causam detrimentos no peso de grãos quando atingem níveis de $7,0 \%$ de óleo, pelo que torna-se possível a obtenção de genótipos de alto teor de óleo e rendimento, com benefícios para o agricultor e a indústria. 
0 baixo teor de óleo nos grãos de milho do Brasil faz com que este seja um artigo de luxo, por ter um preço muito acima do óleo de soja, tornando-se, desta maneira, um produto elitista de consumo restrito. Assim, surge a necessidade de se incrementar o conteúdo de óleo para tornar mais econômica sua produção e atingir maiores benefícios para a sociedade. Torna-se de suma importância conhecer os possiveis efeitos da seleção para alto teor de óleo, sobre as características agro nômicas desejāveis' e determinar se estes têm alguma vantagem ou desvantagem, a fim de se ter novos critérios de seleção no melhoramento genético deste caräter.

Os objetivos do presente trabalho foram: (1) a determinação de parâmetros genéticos; (2) medir o efeito da seleção para teor de óleo sobre características morfológicas da planta e espiga; e ' (3) predizer os possiveis ganhos futuros como resultados da seleção, em quatro populações de milho. 
2. REVISÃO DE LITERATURA

2.1. Composição e Controle Genético do ôleo de Milho

0 conhecimento da composição dos ácidos graxos do óleo de milho é importante porque determina a qualidade nutricional e possível utilizaçäo deste nas aplicações industriais. A respeito, TRIFUNOVIC et alii (1975) e MITRA \& BHATTA (1979), observaram que o óleo de milho é composto de $85 \%$ de ācidos graxos não saturados (oleico C 18:1, linoléico C 18:2 e palmitoléico C 16:1); o restante estä representado pelos ācidos graxos saturados (mirîstico C 14:0, palmítico C 16:0 e esteárico C 18:0). Entretánto, SHADLEY \& WEBER (1986) e PAMIN et alii (1986), manifestaram que a alta qualidade do óleo de milho geralmente está relacionada a uma maior proporção de ácido linoléico e baixas quantidades de ácidos oleico, palmítico e esteärico.

HOPKINS et ali.i (1974) evidenciaram que o gérmen contém de 80 a $84 \%$ de óleo e as outras partes apresentam unicamente de 15 a $20 \%$ do total de óleo no grão. Baseados neste fato, informaram que os grãos com maior proporção de gérmen tem maior teor de óleo e os de menor pro- 
porção de gērmen contēm menor teor de óleo. Da mesma maneira, CURTIS et alii (1968) e MILLER et alii (1981) disseram que o óleo do grão estâ 1o calizado no gērmen e a seleção para porcentagem de óleo leva a um aumento no peso do gérmen, na porcentagem de óleo no gërmen ou em ambos, porque muito pouco óleo está presente no endosperma.

0 conteúdo de óleo nos grãos de milho está sob controle genético e evidências deste fato ê a resposta do teor de óleo a vários métodos de seleção (HOPKINS, 1974; WOODWORTH et alii, 1952; RUSCHELL \& BAUMAN, 1973; DUDLEY, 1977; BIANCO, 1984; ZIMBACK, 1985 e MISEVIC \& ALEXANDER, 1989), assim como a resposta da seleção reversa em gerações avançadas (LENG, 1967).

MILLER et alii (1981) informaram que a porcentagem de óleo é uma característica quantitativa sugerindo SPRAGUE \& BRIMHALL (1949) e DUDLEY (1977), a existêncía.de um grande número de genes envo1vidos na herança do conteûdo de ôleo. Entretanto, o controle genético da composição dos âcidos graxos parece ser completamente variável. Numerosos estudos tem demonstrado um controle simples e multigênico dos diferentes ácidos graxos entre linhagens enđogâmicas (DE LA ROCHE et alii, 1975; PLEWA \& WEBER, 1975; JELLUM \& WIDSTROM, 1983 e WIDSTROM \& JELLUM, 1984). Estes ültimos pesquisadores quando estudaram a lozalização cromossômica dos genes que controlam o âcido oléico e linoléico, indicaram a existência de gene(s) sobre o braço longo do cromossomo 5 e um gene recessivo no braço longo do cromossomo 4 .

ELROUBY \& PENNY (1967); PONELEIT \& BAUMAN (1970);WIDSTROM \& JELLUM (1975); MORENO-GONZALEZ et a $i$ ii (1975), TOSELLO \& GERALDI 
(1980b); MILLER et alii (1981); BIANCO (1984) e ALEXANDER (1988), informaram que a variância genética aditiva é o componente principal que afeta o controle do conteúdo de óleo em milho. MORENO-GONZALEZ et alii (1975), reportaram pouca variação na estimação dos valores da variância de dominância entre a geração $\mathrm{F}_{2}$ e $\mathrm{F}_{6}$, o que estâ em concordância com 0 expressado por DUDLEY (1977), que manifestou que a dominância tem pouca importância na produção de ôleo.

2.2. Fatores que Afetam o Conteúdo de óleo em Milho

Segundo LAMBERT et alii (1967) a quantidade de óleo por grão de milho, sofre mudanças de acordo com a posição dos mesmos na espiga, apresentando maior teor de óleo os localizados na parte central da espiga, devido a sua maior uniformidade na massa dos grãos deste lugar. Da mesma maneira, JELLUM \& MARION ( $\dot{1} 966)$ ao estudar o efeito de posição dạ espiga sobre a quantidade e qualidade do ỏleo, evidenciaram poucas diferenças entre a primeira e segunda espiga para os ácidos palmítico, esteảrico e linolênico: Os grãos da espiga superior tiveram consistentemente, ainda que nem sempre significativo, mais ácido oléico e menos ácido linolênico que os grãos da segunda espiga, além de apresentar a segunda espiga na análise combinada de anos e localidades menor teor de óleo.

MILLER \& BRIMHALL (1951) e CURTIS et alii (1956) determianram que o conteúdo de óleo no milho sofre influência preponderante da fonte materna. $\bar{A}$ conclusões similares chegaram GARWOOD et alii (1970), acrescentando que estes efeitos combinam-se entre a porcentagem de óleo no gêrmen e a proporção de gêrmen para a porcentagem total de 
óleo, devido a diferenças na fisiologia e metabolismo da planta mãe, antes que a efeitos puramente genéticos.

MILLER \& BRIMHALL (1951) e CURTIS et alii (1956), relataram a presença de um efeito pequeno da fonte polinizadora no conteúdo de óleo nos grãos de milho. Assim mesmo, expressaram a necessidade do controle da polinização nos estudos sobre a porcentagem de óleo nos grãos, mas nenhum isolamento especial na produção comercial de variedades com alto teor de ôleo.

2.3. Efeitos da Seleção para Teor de ōleo e suas Alterações Morfológicas

Os primeiros estudos para aumentar o teor de óleo em mi1ho, foram conduzidos por Hopkins em 1896, dentro da variedade Burr's White (HOPKINS, 1974). Este pesquisador logrou alcançar sucessos nas mudanças dos teores de óleo e proteína, mediante a aplicação do método espiga por fileira, dividindo a população original cuja média era de $4,7 \%$ de 61 leo, em Illinois High 0il e Illinois Low 0il. Os resultados conseguidos durante o transcurso de 87 gerações de seleção para teor de óleo na variedade Burr's White, tem sido expressado por diversos pesquisadores (HOPKINS, 1974; SMITH, 1974; WINTER, 1974; WOODWORTH et alii, 1952; LENG, 1962 e DUDLEY et alii, 1974 e ALEXANDER, 1988. Os valores registrados por ALEXANDER (1988) para a geração 87, assinalam que o teor médio de óleo nas subpopulações alto óleo e baixo óleo foi de $21,3 \%$ e $1,2 \%$, respectivamente. 
Com o objetivo de testar a existência de variabilidade ge nētica, após 48 gerações de seleção nas populações Illinois High 0i1 e Illinois Low Oil, LENG (1962) deu início a um teste biológico de seleção reversa, jā que o sistema de seleção empregado, não permitia decompor a variância em seus componentes genéticos e ambientais, reportando que este foi efetivo nas duas subpopulações, após 48 gerações de seleção para composição química.

Para fins comparativos entre dois sistemas de seleção para teor de óleo no grão de milho, SPRAGUE \& BRIMHALL (1950) avaliaram a seleção recorrente e seleção em linhagens endogâmicas, tendo por base 10 espigas que tinham uma média de $7,2 \%$, resultando em superior a seleção recorrente, jā que seu segundo ciclo apresentou uma média de $10,5 \%$ e a seleção nas linhagens endogâmicas $S_{5} 7,5 \%$. Posteriormente SPRAGUE et alii (1952), apresentaram novas evidências sobre a superioridade da seleção recorrente trabalhando na variedade sintētica Stiff Stalk.

RUSCHEL \& BAUMAN (1973) submeteram a população de milho opaco-2 sintético A, a três métodos de seleção com igual intensidade de seleção, para aumentar o teor de óleo nos grãos de milho, a saber: seleção de progênies autofecundadas, de irmãos germanos e meios irmãos, concluindo que os três, foram eficientes, elevando o teor de óleo em média de $0,37 \%$ em duas gerações de seleção. De igual maneira eles expressaram que pelo fato do pequeno número de ciclos executados, não foi possível tirar conclusões mais concretas sobre a eficiência relativa a cada um dos mētodos empregados.

MISOVIC et alii (1980), confrontaram os resultados obtidos após 18 anos de melhoramento para maior conteúdo de óleo de três 
sistemas de seleção (Espiga por fileira, Seleção recorrente e Retrocruzamentos com milhos de teor normal de óleo e alto óleo), manifestando que a seleção recorrente foi o método mais eficiente para elevar o teor de óleo. Ā igual conclusão chegaram MILLER et alïi (1981), após sete ciclos de seleção recorrente, dentro de famílias de meios irmãos na variedade Reid Yellow Dent, logrando aumentar o conteúdo em 5,1\% com relação ao material original. Novas evidências sobre a eficiência da seleção recorrente para aumentar o teor de óleo em populações de milho, tem sido apresentados por GAJIC \& SAVIC (1984) e MISEVIC \& ALEXANDER (1989).

Dentro do contexo da literatura brasileira existem diversos trabalhos que relatam os progressos e perspectivas atravēs da seleção para aumentar a porcentagem de óleo na semente de milho. Entre eles destacam-se a seleção entre e dentro de famílias de meios irmãos no milho Centralmex, com ganho de $6,3 \%$ por ciclo (MIRANDA et alii, 1976); seleção dentro de famílias de meios irmãos na população ESALQ-VD-2, com progressos de $1,44 \%$ por ciclo (BATISTA, 1980); seleção massal nas populações Piranão-VD-2 e Piranão-VF-1 com ganho de 7,12\% e 4,07\%, respectivamente por ciclo (BIANCO, 1984); com igual metodologia no composto braquítico-VD-opaco, subpopulação A e B, obtendo progressos de 2,63\% e 2,77\% por ciclo (ZIMBACK, 1985).

Os trabalhos de seleção para elevar o teor de óleo no grão de milho, tem demonstrado que é possível lograr sucesso, de acordo aos resultados antes mencionados. Não obstante, esta seleção pode levar a mudanças morfolögicas na espiga e grãos, em razão do balanço energético fisiológico da planta, jā que o aumento no teor de óleo, pode originar 
uma redução na quantidade de carbohidratos, trazendo como consequência, uma redução na produção de.grãos (WOODWORTH et alii, 1952; BIANCO, 1984).

WOODWORTH et alii, 1952, expressaram que após 50 gerações de seleção para alto e baixo teor de óleo na variedade Burr's White, as populações de alto óleo apresentaram espigas relativamente pequenas com sementes pequenas, porēm, com embrião bastante grande. A produtividade destas populações foram de aproximadamente $50 \%$ inferior aos hỉbridos locaís e de menor altura da planta e espiga, em relação à população original.

BATISTA \& TOSELLO (1987) após avaliar os efeitos da seleção para alto óleo sobre os caracteres peso de 100 grãos, volume de 100 grãos e densidade de grãos no composto ESALQ-VD-2, relataram uma tendência de elevação para peso e volume de 100 grãos de $1,14 \%$ e 1,52\%, respectivamente e ainda uma redução na densidade de $0,26 \%$, que foram não significativas. Estas alterações referem-se à população alto óleo em re lação à população original. Os resultados anteriores, indicam a possibilidade de aumentar o teor de óleo sem detrimento do rendimento nesta população, o que ajusta-se ao expressado por ALEXANDER \& LAMBERT (1968), que sugeriram que a capacidade de uma planta em produzir carbohidratos e sintetizar óleo são completamente independentes ou ao menos, fisiologicamente independentes entre um intervalo de 4 a $7 \%$ de óleo. DUDLEY et alii (1974), relataram que o aumento da porcentagem de óleo até um nível de $7 \%$, não origina prejuỉzo no peso do grão, jā que o que ocorre, ē um aumento da porcentagem de óleo dentro do gérmen. 
MISEVIC \& ALEXANDER (1989) encontraram ao avaliar 24 ciclos de seleção recorrente fenotípica para porcentagem de óleo, alterações em muitas características morfolögicas da variedade sintética Alexho. Estas alterações foram maiores nos ciclos "per se" que nos "test-cross" para a altura da planta, altura da espiga, comprimento da espiga, peso de grãos e acamamento, além da queda no rendimento de grãos.

2.4. Correlações Entre o Teor de Ōleo e Caracteres da Planta e Espiga 0 conhecimento do grau de associação entre os caracteres da planta, representa um dos caminhos para poupar tempo e esforço na obtenção de ideotipos pelo melhorista. Essa associação pode ser gerada pela pleiotropia, ligação gênica ou ambiente (GOLDENBERG, 1968; FALCONER, 1980). Podendo-se expressar como associação completa, como è o caso de caracteres qualitativos, ou apresentar graus de correlação expresso numericamente pelo coeficiente de correlação $(r)$, o que constitui uma característica das associações quantitativas (GOLDENBERG, 1968). A pleiotropia ocorre quando. um gene afeta dois ou mais caracteres de modo que se o gene estiver segregando, causará variação simultânea nesses caracteres. O grau de correlação originado da pleiotropia expressa o quanto dois caracteres são influenciados pelos mesmos genes, 0 ambiente por sua vez, é uma causa de correlação sempre que dois caracteres são influenciados pelas mesmas condições do ambiente. A correlação de ambiente não é apenas a correlação dos desvios do ambiente, mas sim a somatōria desta com os desvios genéticos não aditivos. As ligações gênicas também podem ser causa de correlação entre caracteres porém são transitörias, especialmente em populações derivadas de cruzamentos entre 
linhagens divergentes (FALCONER, 1980).

A informação dos coeficientes de correlação entre duas va riāveis, è muito ūtil no direcionamento dos trabalhos de melhoramento de plantas para a seleção indireta de caracteres que apresentem baixa herdabilidade e/ou que sejam difíceis de medir, sendo interessante conhecer as associações entre o teor de óleo e caracteres da planta e espiga para o desenvolvimento de genótipos num programa de melhoramento para teor de óleo.

Correlações genéticas baixas e negativas entre a porcentagem de óleo com altura da planta e espiga, tem sido relatadas por ELROUBY \& PENNY (1967); BIANCO et alii (1987), exceção da associação com a altura da espiga que foi positiva e próximo a zero nos valores obtidos pelos primeiros pesquisadores. De acordo com estes resultados a seleção para aumento no teor de óléo, pode conduzir a um leve decréscimo na altura da planta e espiga.

Existe controvérsia quanto aos resultados encontrados na literatura referente ${ }^{\cdot}$ à correlação entre a porcentagem de óleo e peso da espiga. Valores negativos foram encontrados por EIROUBY \& PENNY (1967); DUDLEY et alii (1977); BIANCO et alii (1987); ZANOTTO (1986) e MISEVIC \& ALEXANDER (1989). Entretanto valores positivos foram. evidenciados por BIANCO (1984); ZIMBACK (1985) e ZANOTTO (1986). Porêm, com relação ao peso de 100 grãos ELROUBY \& PENNY (1967); ZIMBACK (1985), encontraram associação negativa, e correlação positiva TOSELLO \& GERALDI (1980a); RAMAN et alii (1983) e MISEVIC \& ALEXANDER (1989). - Esta divergência nos valores encontrados, possivelmente obedece ao tipo 
de população estudada e/ou ao avanço nos programas de melhoramento, permitindo desta maneira quebrar os blocos gênicos entre as características antes ditas.

2.5. Ressonância Magnética Nuclear (NMR) na Determinação do Conteúdo de ōleo e Sua Relação com Métodos C1ássicos

A ressonância magnética nuclear (NMR) tem sido utilizada por muitos pesquisadores nos programas de melhoramento genético de espécies ricas em óleo, com o objetivo de incrementar seu teor em base às análises individuais de cada semente, o que permite superar as dificuldades encontradas nos mëtodos clässicos, onde o critério de seleção está baseado na extração de valores analíticos obtidos de uma alíquota de vārias sementes, forçando ao melhorista tomar seu critērio de seleção com base em médias de progênies, antes que nas diferenças individuais dentro de cada família, diminuindo o progresso genético da seleção BAUMAN et alii, 1963).

TIWARI et alii (1974) relataram valores similares, sobre resultados comparativos obtidos pelas técnicas NMR e extração por tetrocloreto de carbono em sementes de girassol, amendoim e brassica. Quando compararam os dados entre repetições, estes foram mais próximos por NMR que pela outra metodologia, por ter menor risco de erro, ser simples e fácil. Alēm disso, o NMR permite, em casos de dúvidas, repetir a análise de qualquer amostra porque esta técnica não é destrutiva. Conway \& Earle citados por BIANCO (1984), relataram uma correlação de $r=0,99$ entre as técnicas NMR e extração por solvente nas determinações do conteúdo de óleo em sementes de milho. 
ROBERTSON \& WINDHAM (1981) evidenciaram o comportamento de três métodos na determinação do conteūdo de óleo em sementes de girassol, NMR, NIR ("Near Infrared Reflectance") e extração por gravimetria, utilizando oito amostras de sementes de diferentes conteủdos de óleo e cinco repetições, registrando dinferenças não significativas entre suas médias, embora o desvio padrão e coeficiente de variação do NMR tenha sido menor que dos outros dois.

BAUMAN et alii (1963, 1965) utilizaram a técnica NMR como ajuda para avaliar a potencialidade desta metodologia no desenvolvimento de linhagens com maiores teores deóleo, mediante as análises de 289 grãos individuais de milho pertencentes à geração $\mathrm{F}_{2}$ do cruzamento $\mathrm{H} 4 \times 0 \mathrm{~h} \mathrm{45}$, os quais registraram uma variação de 2,70 a 5,40\% de óleo e 256 grãos da progênie $\mathrm{F}_{2}$ com variação similar 3,00 a 5,40\%, indicando a existência de correlações fortes e significativas $r=0,75$ entre sementes $F_{2}$ e sua respectiva progênie. Entre seis famîlias $F_{3}$ è suas respectivas progênies as correlações foram altamente significativas com 5 varianđo de 0,54 a 0,84. Estes resultados tornaram possível concluir que as diferenças entre grãos individuais são de natureza hereditária apesar da considerāvel redução da heterozigose. 0 ganho que eles conseguiram através da seleção individual nàs gerações $\mathrm{F}_{2}$ e $\mathrm{F}_{3}$ foram de 0,71 e $0,48 \%$, respectivamente.

A determinação do conteúdo de óleo feita pelo método NMR (Ressonância Nuclear Magnética), quantifica o teor de óleo na própria semente, enquanto que o método de extração utilizando o solvente hexano, desenvolvido por Tosello (1978) e citado por BATISTA (1980), ZIMBACK (1985) e ZANOTTO (1986), fornece o conteúdo de óleo pela diferença de peso da amostra antes e depois da extração. 
As determinações do teor de óleo na semente, baseiam-se no princípio da radiofreqüência por spins nucleares orientados por imã. Os sinais de NMR são detectados pela técnica de pulso, que consiste na aplicação de um pulso de radiofreqüência ( $r f$ ) com freqüência igual a freqüência de precessão do núcleo (28 $\mathrm{MH}_{\mathrm{z}}$ para o hidrogênio). 0 pulso que tem a duração de alguns microsegundos, tem a finalidade de deslocar os spins da posição de equilỉbrio, voltando rapidamente a sua posição inicial, induzindo o sinal de NMR, que é detectado pelo aparelho e sua intensidade é proporcional à quantidade de hidrogênios presentes na amostra (Colnago, 1989).

Os principais constituintes da semente contendo hidrogênio são os carbohidratos e as proteínas que estão no estado sổido e à água e o ôleo que são lỉquidos. Os sinais provenientes dos constituintes sōlidos decaem rapidamente após o pulso (menos de 100 microsegundos) enquanto que o sinal da água e óleo demoram vários milisegundos. Assim para eliminar a interferência dos constituintes sôlidos, analisa-se o sinal em 150 microsegundos e neste intervalo de tempo, o sinal é devido apenas ao óleo, já que as sementes estiveram submetidas a secagem e o teor de óleo, é quanti ficado com o auxílio da curva de calibração (TIWARI et alii, 1974).

As principais vantagens da técnica de NMR sobre os métodos quỉmicos convencionais de análise de óleo na semente são: maior velocidade e segurança na avaliação do teor de óleo, não destrói as sementes o que representa uma ajuda na seleção de sementes com maior teor de óleo entre uma grande quantidade de progênies, não usa produtos químicos e os dados são automaticamente armazenados em arquivos no computador (COLNAGo, 1989). 
3. MATERIAL E MÉTODOS

3.1. Material

Na presente pesquisa as populações objeto deste estudo, foram Piranão VD-2-MI original. Piranão VD-2-MI Alto óleo; Piranão VF-1-MI original e Piranão VF-1-MI Alto óleo.

Piranão VD-2-MI orïginal e Piranão VF-1-MI original correspondem à versão braquítica das populações ESALQ VD-2 e ESALQ VF-1, obtidas por cruzamentos e retrocruzamentos, usando-se a variedade Piranão como pai não recorrente e fonte do gene braquítico-2 $\left(\mathrm{br}_{2}\right)$. PATERNIANI et alii (1977), descrevem o processo de obtenção desses dois compostos. Após as populações braquỉticas foram submetidas a três ciclos de seleção massal e três ciclos de seleção entre e dentro de famîlias de meios irmãos. Ā fim de uniformizar a arquitetura da planta, foi praticada uma seleção branda em cada população.

Piranão VD-2-MI-Ao e Piranão VF-1-MI-AO originaram-se por seleção para teor de óleo nos grãos das populações originais e representam o terceiro ciclo de seleção recorrente para alta concentração de öleo empregando NMR (TOSELLO, 1989) ${ }^{2}$.

I TOSELlO, 1989. (Informação pessoal). 
Piranão VD-2-MI original caracteriza-se por possuir plan tas braquíticas, boa produtividade, grãos amarelos dentados, largos e longos.

Piranão VF-1-MI original caracteriza-se por possuir plan tas braquíticas, boa produtividade, grãos duros e de cor laranja.

Os genótipos constantes utilizados como testemunhas neste estudo, foram o hỉbrido duplo AG 352-B da Empresa Agroceres e a variedade Piranão VF-1 prolífico, desenvolvida no Departamento de Genética da ESALQ.

\subsection{Mêtodos}

Execução Experimental

No ano agrícola de $: 1987 / 88$, de cada população Piranão VD-2-MI original, Piranão VD-2-MI-A0, Piranão VF-1-MI original e Piranão VF-1-MI-A0, foram utilizadas 100 progênies de meios irmãos, para o desenvolvimento experimental deste trabalho.

As progênies das respectivas populações, foram avaliadas independentemente, na ārea experimental da Caterpillar, Piracicaba, São Paulo, usando o delineamento experimental em látice $10 \times 10$, com três repetições. Cada parcela foi constituída de uma fileira de 4,80m de com primento, espaçadas entre si de $1,0 \mathrm{~m}$, e, entre covas, de $0,20 \mathrm{~m}$. Cada cova recebeu duas sementes, deixando-se após o desbaste, uma planta por cô va, totalizando 25 plantas por parcela. Os tratos culturais obedeceram aos padrões de cultivos comerciais. 
Dentro de cada progênie cerca de cinco plantas competitivas, foram amostradas para se obter informações relacionadas com os seguintes caracteres:

1. Altura da planta: distância em metros, entre a superfỉcie do solo, contígua ao colo da planta, e a inserção da folha superior (folha bandeira), determinada através de régua dividida em unidades de 5 centimetros;

2. Altura da espiga: distância em metros, entre a superfície do solo, contígua ao colo da planta, e a inserção da primeira espiga, obtida pelo emprego da régua anteriormente'descrita;

3. Comprimento da espiga: distância em centímetros, da base da espiga até a parte terminal da mesma, mediante uma régua com um dispositivo semelhante a um paquímetro;

4. Diâmetro da espiga: relativo ao diâmetro, em centímetros, da porção mediana de cada espiga mediante o emprego do aparél ho anteriormente descrito;

5. Diâmetro do sabugo: relativo ao diâmetro, em centỉmetros, da porção mediana de cada sabugo, mediante o emprego do aparelho anteriormente descrito;

6. Número de fileiras por espiga: mediante a contagem do número de fileiras definidas em cada espiga;

7. Número de grãos por fileira: foi escolhida uma fileira representativa de cada espiga e feita a contagem dos grãos; 
8. Comprimento de grãos: diferença entre o diâmetro da espiga e o diâmetro do sabugo dividido por dois;

9. Largura de grãos: foi feita pelo cālculo da ārea ocupa da pelos grãos e dividida pelo número de fileiras;

10. Peso de grãos/planta: estabelecido após o debulhamen to manual das espigas, em gramas, utilizando-se balança da marca Toledo com capacidade máxima para cinco quilos e sensibilidade ao nỉvel de gramas;

11. Peso do sabugo: determinado após o debulhamento manual das espigas, em gramas, com a balança antes dita.

12. Peso de 100 grãos: foi determinado a partir de uma amostra de 100 grãos tomada aleatoriamente de cada espiga e obtido seu peso, em gramas;

13. Densidade dos grãos: apōs a obtenção do peso de 100 grãos, foi determinado o volume de 100 grãos, pela diferença de volume medido pelo deslocamento da coluna de etanol, em mililitros; posteriormente a relação entre estes caracteres forneceu a densidade, em gramas por mililitro;

14. Porcentagem de óleo: foi determinada em 10 grãos selecionados visualmente para uniformidade de tamanho (peneira 22) e subme tidos a anālise individual.

Além destas avaliações realizadas individualmente, foram tomados dados relacionados com a produtividade por parcela, no qual participaram todas as plantas de cada unidade experimental, incluindo os pe sos de espigas das cinco plantas amostradas. O termo produtividade por 
parcela é equivalente ao rendimento por parcela.

0 rendimento de cada unidade experimental, foi corrigido para umidade padrão de $15,5 \%$, conforme a seguinte fórmula utilizada por BIANCO (1984) e ZIMBACK (1985)

$$
\mathrm{PC}_{15,5} \%=\frac{\mathrm{PC}(\mathrm{U}-1)}{0,845}
$$

onde:

$\mathrm{PC}_{15,5} \%$ = Peso de campo corrigido para $15,5 \%$ de umidade;

PC = Peso de campo observado;

$\mathrm{U} \quad=$ Umidade observada em cada unidade experimental;

0,845 = Fator relacionado à correção do teor de umidade para padrão de $15,5 \%(0,845=1,000-0,155)$.

A seguir, foi feito correção para estande empregando-se a förmula de ZUBER (1942), jā corrigido para umidade

$$
\mathrm{PCC}=\mathrm{PC}_{15,5} \cdot \frac{\mathrm{T}-0,3 \mathrm{~F}}{\mathrm{~T}-\mathrm{F}}
$$

onde:

$$
\begin{aligned}
& \text { PCC } \quad \text { Peso de campo corrigido para estande ideal e umidade; } \\
& \mathrm{PC}_{15,5 \%}=\text { Peso de campo corrigido para } 15,5 \% \text { de umidade; } \\
& \mathrm{T} \quad=\text { Número de plantas ideal por parcela (25); } \\
& \mathrm{F} \quad=\text { Número de plantas perdidas por parcela. }
\end{aligned}
$$

Este ajuste adiciona 0,7 da produção média para cada plan ta perdida e considera que 0,3 é recuperado pelas plantas vizinhas à fa1ha. 


\subsubsection{Anālise de Laboratörio}

As medições da porcentagem de óleo foram feitas em 10 sementes individuais de cada espiga, as quais foram previamente submetidas a secagem a $60^{\circ} \mathrm{C}$ durante 24 horas e armazenadas em secador de vidro para manter constante a umidade.

Para fazer as anālises do conteūdo de óleo nas sementes de milho, foram seguidos os seguintes passos:

1. Determinação de uma curva de calibração com padrões de óleo de milho conhecidos;

2. Medição do peso seco de cada semente em gramas;

3. Leitura no espectrômetro de ressonância que fornece a porcentagem de óleo de cada semente, com relação a seu peso seco.

As análises da porcentagem de ólleo para as 10 sementes, foram feitas individualmente e seguidamente foi calculado o valor médio da progênie atravēs da média aritmética dos valores individuais, pelas limitações do aparelho em sua capacidade de anālises em grupo.

3.2.2. Estimativas de parâmetros estatísticos e genéticos

Com o propósito de avaliar os efeitos da seleção para teor de óleo na semente de milho, foram consideradas quinze características em cada uma das quatro populações submetidas a estudo.

Os dados foram analisados como blocos ao acaso, uma vez que os látices não apresentaram uma eficiência superior a $110 \%$, com relação aos blocos. Na Tabela 1, encontram-se as esperanças matemáticas dos quadrados médios das anālises de variânvia ao nível de médias de par celas e plantas individuais (GERALDI; 1977). 


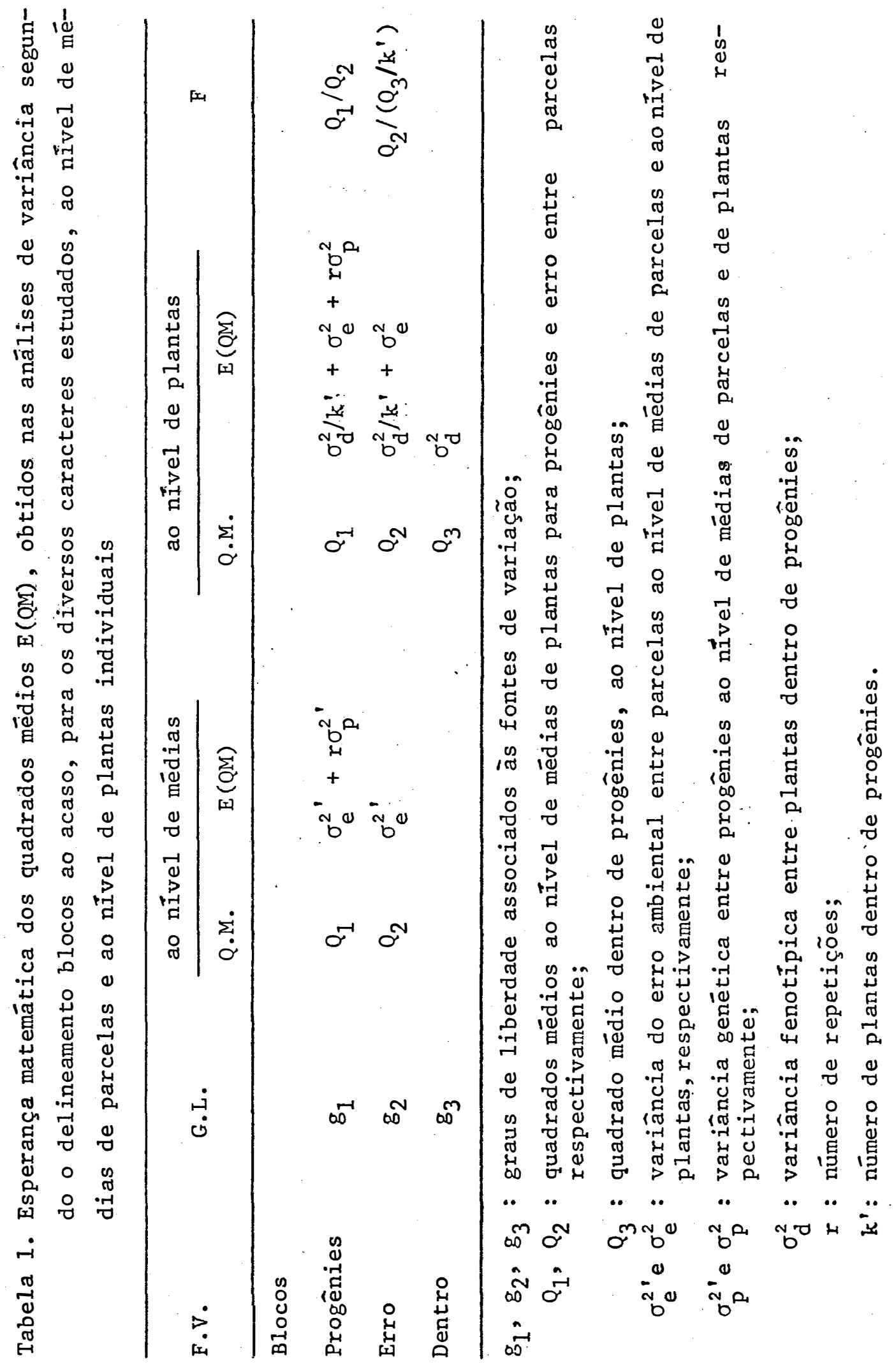


Para a análise dos caracteres rendimento, altura da planta, altura da espiga, comprimento de grãos e largura de grãos, utilizouse o seguinte modelo matemático (GERALDI, 1977).

$$
\dot{x}_{i j}=\mu+p_{i}+b_{j}+e_{i j}
$$

onde:

$$
\begin{aligned}
& x_{i j}=\text { observações da progênie } 1 \text {, no bloco } j \text {; } \\
& \mu=\text { média geral fixa, } \therefore \mathrm{E}(\mu)=\mu \text { e } \mathrm{E}\left(\mu^{2}\right)=\mu^{2} \text {; } \\
& \mathrm{p}_{i}=\text { efeito da progênie } \mathrm{i}(\mathrm{i}=1,2, \ldots, \mathrm{I}) \text {, aleatōria } \therefore \mathrm{E}\left(\mathrm{p}_{\mathbf{i}}^{2}\right)=0 \text { e } \\
& E\left(p_{i}^{2}\right)=\sigma_{p}^{2} ; \\
& \mathrm{b}_{j}=\text { efeito do bloco } \mathbf{j}(\mathbf{j}=1,2,3) \text {, aleatório } \therefore E\left(\mathrm{~b}_{j}\right)=0 \text { e } \\
& E\left(b_{j}^{2}\right)=\sigma_{b}^{2} \text {; } \\
& e_{j}=\text { efeito do erro experimental associado à progênie } i \text { na repeti- } \\
& \text { ção } j, e_{u j} \cap N\left(0, e^{)} \text {, isto } \bar{e}: E\left(e_{i j}\right)=0 \text { e } E\left(e_{i j}^{2}\right)=\sigma_{e}^{2}\right. \text {;. }
\end{aligned}
$$

onde:

$\sigma_{\mathrm{p}}^{2}$ : variância genética entre progênies;

$\sigma_{b}^{2}$ : variância entre blocos;

$\sigma_{\mathrm{e}}^{2}$ : variância do erro ao nível de parcelas.

Para os caracteres densidade dos grãos, comprimento da espiga, diâmetro da espiga, número de fileiras, número de grãos/fileira, diâmetro do sabugo, peso de 100 grãos, porcentagem de óleo, peso do sabu go e peso de grãos, utilizou-se o seguinte modelo matemätico (GERALDI, 1977). 


$$
x_{i j k}=\mu+p_{i}+b_{j}+e_{i j}+d_{i j k}
$$

onde:

$$
\begin{aligned}
& x_{i j k}=\text { observações do indivỉduo } k \text { da progênie } i \text { no bloco } j \text {; } \\
& \mu=\text { média geral fixa, } \therefore \mathrm{E}(\mu)=\mu \text { e } \mathrm{E}\left(\mu^{2}\right)=\mu^{2} \text {; } \\
& \mathrm{p}_{\mathrm{i}}=\text { efeito da progênie } \mathrm{i}(\mathrm{i}=1,2, \ldots, \mathrm{I}) \text {, aleatória, } \therefore \mathrm{E}\left(\mathrm{p}_{\mathrm{i}}=0\right. \text { e } \\
& E\left(p_{i}^{2}\right)=\sigma_{p}^{2} ; \\
& \mathrm{b}_{i}=\text { efeito do bloco } \mathrm{j}(\mathrm{j}=1,2,3) \text {, aleatōrio, } \therefore \mathrm{E}\left(\mathrm{b}_{j}\right)=0 \text { e } \\
& E\left(b_{j}^{2}\right)=\sigma_{b}^{2} ; \\
& e_{i j}=\text { efeito do erro experimental associado à progênie } i \text { na repe- } \\
& \text { tição } j, e_{i j} \cap N\left(0, \sigma_{e}^{2}\right) \text {, isto } \bar{e}: E\left(e_{i j}\right)=0 \text { e } E\left(e_{i j}^{2}\right)=\sigma_{e}^{2} \text {; } \\
& d_{i j k}=\text { efeito do indivíduo } k \text { da progênie } i \text { no bloco } j \text {, } \\
& d_{i j k} \cap N\left(0, \sigma_{d}^{2}\right) \text {, isto é: } E\left(d_{i j k}\right)=0 \text { e } E\left(d_{i j k}^{2}\right)=\sigma_{d}^{2}
\end{aligned}
$$

onde:

$\sigma_{\mathrm{p}}^{2}$ : variância genética entre progênies;

$\sigma_{\mathrm{b}}^{2}$ : variância entre blocós;

$\sigma_{\mathrm{e}}^{2}$ : variância do erro ao nível de parcelas;

$\sigma_{\mathrm{d}}^{2}$ : variância fenotípica entre plantas dentro de parcelas.

As anālises de variância foram realizadas com médias de parcela, em gramas por planta (g/planta) para rendimento, em metros por plan ta (m/planta) para altura da planta e espiga, em número de fileiras por espiga (nf/espiga) para o número de fileiras, em número de grãos por fileira por espiga (ngf/espiga) para o número de grãos por fileira, em cen tỉmetros por espiga (cm/espiga) para o comprimento e diâmetro da espiga, em centỉmetros por grãos (cm/grãos) para o comprimento e largura de grãos, em centímetros por sabugo ( $\mathrm{cm} / \mathrm{sabugo}$ ) para o diâmetro do sabugo, em gramas 
por sabugo (g/sabugo) para o peso do sabugo, em gramas por espiga (g/espiga) para o peso de grãos, em gramas (g) para o peso de 100 grãos, em gramas por centímetro củbico $\left(\mathrm{g} / \mathrm{cm}^{3}\right)$ para a densidade dos grãos e em porcentagem (\%) para o conteúdo de óleo. Para os caracteres rendimento, altura da planta, altura da espiga, comprimento de grãos e largura de grãos, não obtiveram-se os quadrados médios dentro; enquanto que nos demais caracteres estes foram determinados.

0 tamanho das amostras coletadas dentro de parcelas, para cada carāter, mostrou-se variävel $\left(k^{\prime} \leq 5\right)$, sendo determinado pela média harmônica dos números de plantas relacionadas às diferentes amostragens $\left(K^{\prime} h\right)$.

Foi seguida a metodologia apresentada por VENCOVSKY (1969, 1987), para estimação dos componentes da variância e parâmetros afins.

Assim a estimativa da variância genética entre as progênies de meios irmãos $\left(\hat{\sigma}_{\mathrm{p}}^{2}\right)$, da variância do erro ambiental entre parcelas $\left(\hat{\sigma}_{e}^{2}\right)$ e da variância fenotípica dentro de progênies $\left(\hat{\sigma}_{d}^{2}\right)$ de cada população, ao nîvel de plantas, foram determinadas a partir dos quadrados médios, atravēs das seguintes operações algēbricas:

$$
\begin{aligned}
& \hat{\sigma}_{\mathrm{p}}^{2}=\frac{Q_{1}-Q_{2}}{\mathrm{r}} \\
& \hat{\sigma}_{\mathrm{e}}^{2}=Q_{2}-\left(Q_{3} / \mathrm{k}^{\mathrm{\prime}}\right) \\
& \hat{\sigma}_{\mathrm{d}}^{2}=Q_{3}
\end{aligned}
$$

A partir das estimativas anteriores, foram calculadas estimativas das variâncias genética aditiva $\left(\hat{\sigma}_{A}^{2}\right)$, fenotípica entre plantas 
$\left(\hat{\sigma}_{\mathrm{F}}^{2}\right)$, fenotípica entre médias de progênies $\left(\widehat{\sigma}_{\overline{\mathrm{F}}}^{2}\right)$ e coeficientes de herdabilidade no sentido restrito, aos níveis de plantas $\left(\hat{h}_{\dot{i}}^{2}\right)$ e de médias de progênies $\left(\hat{\mathrm{h}}_{\mathrm{m}}^{2}\right)$ conforme a metodologia de GERALDI (1977) e VENCOVSKY (1987).

$$
\begin{aligned}
& \hat{\sigma}_{\mathrm{A}}^{2}=4 \hat{\sigma}_{\mathrm{p}}^{2} \\
& \hat{\sigma}_{\mathrm{F}}^{2}=\hat{\sigma}_{\mathrm{d}}^{2}+\hat{\sigma}_{\mathrm{e}}^{2}+\hat{\sigma}_{\mathrm{p}}^{2} \\
& \hat{\sigma}_{\mathrm{F}}^{2}=\hat{\sigma}_{\mathrm{d}}^{2} / \mathrm{k}^{\prime}+\hat{\sigma}_{\mathrm{e}}^{2} / \mathrm{r}+\hat{\sigma}_{\mathrm{p}}^{2} \\
& \hat{\mathrm{h}}_{\mathrm{i}}=\hat{\sigma}_{\mathrm{A}}^{2} / \widehat{\sigma}_{\mathrm{F}}^{2} \\
& \hat{\mathrm{h}}_{\mathrm{m}}=\hat{\sigma}_{\mathrm{p}}^{2} / \hat{\sigma}_{\mathrm{F}}^{2}
\end{aligned}
$$

As anālises das características que não incluíram a variação dentro de progênies, foram obtidos os seguintes parâmetros:

$$
\begin{aligned}
& \hat{\sigma}_{\mathrm{p}^{\prime}}^{2}=\frac{\mathrm{Q}_{1}-Q_{2 r}}{\mathrm{r}} \\
& \hat{\sigma}_{\mathrm{A}}^{2}=4 \hat{\sigma}_{\mathrm{P}^{\prime}}^{2} \\
& \hat{\sigma}_{\mathrm{e}^{\prime}}^{2}=\mathrm{Q}_{2} \\
& \hat{\sigma}_{\overline{\mathrm{F}}}^{2}=\hat{\sigma}_{\mathrm{e}^{\prime}}^{2} / \mathrm{r}+\hat{\sigma}_{\mathrm{p}^{\prime}}^{2} \\
& \hat{\mathrm{h}}_{\mathrm{m}}=\hat{\sigma}_{\mathrm{p}}^{2} / \hat{\sigma}_{\overline{\mathrm{F}}}^{2}
\end{aligned}
$$

0 cálculo dos coeficientes de variação experimental ( $\left.\mathrm{CV}_{\mathrm{e}}{ }^{\%}\right)$ e genético $\left(\mathrm{CV}_{\mathrm{g}} \%\right)$ e o indice de variação (b), foram obtidos da seguinte maneira: 


$$
\begin{aligned}
& \mathrm{CV}_{\mathrm{e}} \%=\left(\hat{\sigma}_{\mathrm{e}}^{2} / \overline{\mathrm{x}}\right) \cdot 100 \\
& \mathrm{CV}_{\mathrm{g}} \%=\left(\widehat{\sigma}_{\mathrm{p}}^{2} / \overline{\mathrm{x}}\right) \cdot 100 \\
& \mathrm{~b}=\mathrm{cv}_{\mathrm{g}} \% / \mathrm{cV}_{\mathrm{e}} \%
\end{aligned}
$$

onde:

$\overline{\mathbf{x}}=$ a média de um determinado carāter.

\subsubsection{Anāilise de covariância}

A metodologia proposta por KEMPTHORNE (1966) foi utilizada para a obtenção dos produtos médios entre a porcentagem de óleo e os demais caracteres avaliados nas progênies de meios irmãos das respectivas populações. Atravēs deste procedimento pode-se obter a anālise da covariância apenas com a utilização da análise da variância. Assim para a obtenção da covariância entre duas características $x$ e y, deve-se obter a análise da varịancia de $\mathrm{x}, \mathrm{y}$ e $\mathrm{z}$, sendo $\mathrm{z}=\mathrm{x}+\mathrm{y}$. Desta forma:

$$
\begin{aligned}
E\left(z^{2}\right) & =E(x+y)^{2}=E\left(x^{2}+2 x y+y^{2}\right)= \\
& =E(x)^{2}+E(2 x y)+E(y)^{2} \\
E\left(z^{2}\right) & =E\left(x^{2}\right)+2 E(x \cdot y)+E\left(y^{2}\right)
\end{aligned}
$$

sendo:

$$
\begin{aligned}
& E\left(z^{2}\right)=\sigma_{y}^{2} z \\
& E\left(x^{2}\right)=\sigma_{y}^{2} x \\
& E\left(y^{2}\right)=\sigma_{y}^{2} y \\
& E(x \cdot y)=\operatorname{cov}(x \cdot y)
\end{aligned}
$$


tem-se

$$
\begin{aligned}
& \sigma^{2} z=\sigma^{2} x+2 \operatorname{cov}(x \cdot y)+\sigma^{2} y \\
& \operatorname{cov}(x, y)=1 / 2\left(\sigma^{2} z-\sigma^{2} x-\sigma^{2} y\right)
\end{aligned}
$$

portanto

$$
P M(x, y)=1 / 2\left(Q_{z}-Q M_{x}-Q M_{y}\right)
$$

Os produtos médios dentro de progênies nas situações que permitiram seus cálculos, estes foram obtidos independentemente e de maneira semelhante aos quadrados médios dentro de progênies.

Considerando que as anālises de rendimento foram efetuadas com totais de parcela onde $k=25$ plantas por parcela e as anālises de por centagem de ōleo, efetuadas com médias de parcela onde $k^{\prime}=5$ plantas por parcela, tornou-se necessāria a obtenção de uma esperança dos produtos mé dios devidamente adequada a esta si€uação, tornando possível a estimação das diferentes covariâncias contidas nos produtos médios assim obtidos conforme o demonstrado por GERALDI et aZii (1978).

As esperanças matemáticas dos produtos mēdios das anālises de covariância, ao nível de médias de parcelas e ao nível de plantas individuais estão contidas na Tabela 2. A partir desta tabela considerando as anālises que incluíram a fonte de variação dentro de progênies, foram obtidas estimativas de covariâncias genēticas e fenotípicas entre caracte res para cada população, do seguinte modo: 


$$
\begin{aligned}
& \operatorname{cô}_{\mathrm{d}}=\mathrm{P}_{3} \text {; } \\
& \text { Côv } \mathrm{e}_{\mathrm{e}}=\mathrm{P}_{2}-\left(\mathrm{P}_{3} / \mathrm{k} !\right) \text {; } \\
& \text { Côv }{ }_{p}=\left(P_{1}-P_{2}\right) / r \\
& \mathrm{CÔV}_{\mathrm{A}}=4 \mathrm{Côv}_{\mathrm{p}} \text {; } \\
& \mathrm{cô} \mathrm{F}_{\mathrm{F}}=\mathrm{cô} \mathrm{v}_{\mathrm{d}}+\mathrm{cô} \mathrm{v}_{\mathrm{e}}+\mathrm{cô} \mathrm{v}_{\mathrm{p}} \text {; } \\
& \operatorname{cô}_{\overline{\mathrm{F}}}=\operatorname{côv}_{\mathrm{d}} / \mathrm{k}^{\prime} \mathrm{r}+\mathrm{CÔ} \mathrm{v}_{\mathrm{e}} / \mathrm{r}+\mathrm{COOV}_{\mathrm{p}} \text {; }
\end{aligned}
$$

onde:

$$
\begin{aligned}
\operatorname{CôV}_{\mathrm{A}}(\mathrm{x}, \mathrm{y})= & \text { covariância genética aditiva entre caracteres } \mathrm{x} \text { e } \mathrm{y} ; \\
\mathrm{CÔV}_{\mathrm{F}}(\mathrm{x}, \mathrm{y})= & \text { covariância fenotípica entre caracteres } \mathrm{x} \text { e } \mathrm{y} \text {, ao nível } \\
& \text { de plantas; } \\
\mathrm{CÔV}_{\overline{\mathrm{F}}}(\mathrm{x}, \mathrm{y})= & \text { covariância fenotípica entre médias de progênies para os } \\
& \text { caracteres } \mathrm{x} \text { e } \mathrm{y} .
\end{aligned}
$$




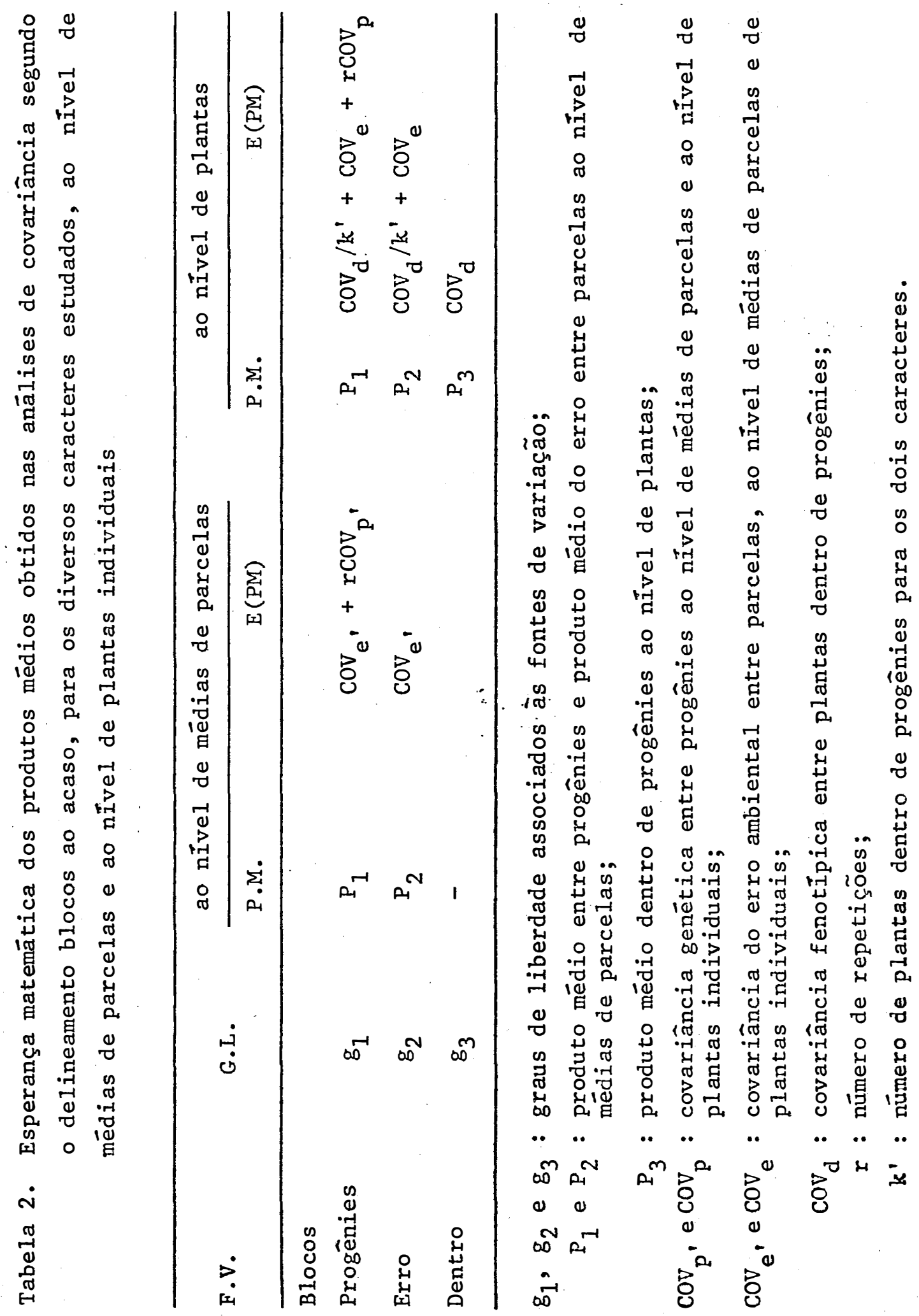


Naquelas anälises que não envolveram a variação dentro de progênies, foram estimados os parâmetros $\mathrm{CÔV}_{\mathrm{e}^{i}}, \mathrm{CÔV}_{\mathrm{p}^{\prime}}, \mathrm{CôV}_{\mathrm{A}}$ e $\mathrm{CÔV}_{\overline{\mathrm{F}}}$. Deste modo, tem-se que

$$
\begin{aligned}
& \operatorname{côv}_{\mathrm{e}^{\prime}}=\mathrm{P}_{2} \\
& \mathrm{Côv}_{\mathrm{p}^{\prime}}=\mathrm{P}_{1}-\mathrm{P}_{2} / \mathrm{x} \\
& \operatorname{côv}_{\mathrm{A}}=4 \cdot \mathrm{Cô}_{\mathrm{p}^{\prime}} \\
& \operatorname{côv}_{\overline{\mathrm{F}}}=\mathrm{Côv}_{\mathrm{e}^{\prime}} / \mathrm{r}+\operatorname{cô} \mathrm{p}_{\mathrm{p}}
\end{aligned}
$$

As estimativas de correlações genéticas e fenotípicas entre a porcentagem de óleo e os outros caracteres considerados em estudo, foram calculados de acordo com o procedimento relatado por FALCONER (1980) e KEMPTHORNE (1966):

$$
\begin{aligned}
& \hat{r}_{A}(x, y)=\frac{\operatorname{cov}_{A}(x, \dot{y}) \ldots}{\sqrt{\hat{\sigma}_{A}^{2} x \cdot \hat{\sigma}_{A}^{2} y}} ; \\
& \hat{\mathrm{r}}_{\mathrm{F}}(\mathrm{x}, \mathrm{y})=\frac{\operatorname{cov}_{\mathrm{F}}(\mathrm{x}, \mathrm{y})}{\sqrt{\hat{\sigma}_{\mathrm{F}}^{2} \mathrm{x} \cdot \hat{\sigma}_{\mathrm{F}}^{2} \mathrm{y}}} ; \\
& \hat{\mathrm{r}}_{\overline{\mathrm{F}}^{\mathrm{k}}}(\mathrm{x}, \mathrm{y})=\frac{\mathrm{COO}_{\overline{\mathrm{F}}}(\mathrm{x}, \mathrm{y})}{\sqrt{\hat{\sigma}_{\overline{\mathrm{F}}}^{2} \mathrm{x} \cdot \hat{\sigma}_{\overline{\mathrm{F}}}^{2} \mathrm{y}}}
\end{aligned}
$$

onde:

$$
\begin{aligned}
\hat{\mathrm{r}}_{\mathrm{A}}(\mathrm{x}, \mathrm{y})= & \text { coeficiente de correlação genética aditiva entre os carac- } \\
& \text { teres } \mathrm{x} \text { e } \mathrm{y} ;
\end{aligned}
$$




$$
\begin{aligned}
\hat{\mathrm{r}}_{\mathrm{F}}(\mathrm{x}, \mathrm{y})= & \text { coeficiente de correlação fenotípica entre os caracteres } \\
& \mathrm{x} \text { e } \mathrm{y}, \text { ao nível de plantas; } \\
\hat{\mathrm{r}}_{\overline{\mathrm{F}}}(\mathrm{x}, \mathrm{y})= & \text { coeficiente de correlação fenotípica entre os caracteres } \\
& \text { x e y, ao nível de médias de progênies. }
\end{aligned}
$$

3.2.4. Obtenção das estimativas dos ganhos genéticos e respostas correlacionadas com a seleção

As estimativas dos progressos genēticos esperados foram determinados conforme os procedimentos relatados por VENCOVSKY (1987), pa ra diferentes processos de seleção.

Para rendimento, altura de planta, altura da espiga, comprimento de grãos e largura de grãos, estimou-se o ganho genético espeṛado entre progênies de meios irmãos em ambos os sexos:

$$
\Delta \hat{\mathrm{G}}_{1}=i \cdot \frac{1 / 4 \hat{\sigma}_{\mathrm{A}}^{2}}{\sqrt{\hat{\sigma}_{\mathrm{p}^{\prime}}^{2}+\hat{\sigma}_{\mathrm{e}^{1}}^{2} / \mathrm{r}}}
$$

Para os demais caracteres temos

$$
\Delta \hat{G}_{2}=i_{1} \cdot \frac{1 / 4 \hat{\sigma}_{A}^{2}}{\sqrt{\hat{\sigma}_{p}^{2}+\hat{\sigma}_{e}^{2} / r+\hat{\sigma}_{e}^{2} / k^{\prime} r}}+i_{2} \cdot \frac{3 / 8 \hat{\sigma}_{A}^{2}}{\sqrt{\hat{\sigma}_{d}^{2}}}
$$

onde:

$\Delta \widehat{G}_{1}=$ ganho genético esperado com seleção entre médias de famílias de meios irmãos em ambos os sexos; 
$\Delta \widehat{G}_{2}=$ ganho genético esperaḍo com seleção entre médias de famílias de meios irmãos em ambos os sexos e dentro de famillias em um só sexo;

$\mathbf{i}=$ coeficiente associado à porcentagem de indivíduos selecionados.

As respostas correlacionadas à seleção para os caracteres rendimento, altura da planta, altura da espiga, comprimento de grãos e largura de grãos, foram calculadas de acordo aos procedimentos apresentados por FALCONER (1980) e ZIMBACK (1985).

$$
\operatorname{RC}(y / x)_{1}=i_{x} \cdot \frac{1 / 4 \operatorname{Cov}_{A}(x, y)}{\sqrt{\left(\hat{\sigma}_{p^{\prime}}^{2}+\hat{\sigma}_{e^{\prime} / r}^{2}\right)_{x}}}
$$

Para os demais caracteres temos:

$$
\operatorname{RC}(y / x)_{2}=i_{1 x} \cdot \frac{1 / 4 \operatorname{cô}_{A}(x, y)}{\sqrt{\left[\hat{\sigma}_{p}^{2}+\frac{\hat{\sigma}_{e}^{2}}{r}+\frac{\hat{\sigma}_{d}^{2}}{k^{1} r}\right]_{x}}}+i_{2 x} \cdot \frac{3 / 8 \operatorname{Côv}_{A}(x, y)}{\sqrt{\hat{\sigma}_{d_{x}}^{2}}}
$$

onde:

$$
\begin{aligned}
\operatorname{RC}(y / x)_{1}= & \text { resposta correlacionada esperada no carāter } y, \text { quando a } \\
& \text { seleção é praticada em } x \text {, entre médias de famĩlias de } \\
& \text { meios irmãos; }
\end{aligned}
$$

$\mathrm{RC}(\mathrm{y} / \mathrm{x})_{2}=$ resposta correlacionada esperada no caráter $\mathrm{y}$, quando a seleção é praticada em $x$, entre médias de famílias de meios irmãos nos dois sexos e fenotipica dentro de famílias em um só sexo. 
3.2.5. Determinação da precisão das estimativas obtidas.

Foram determinados intervalos de confiança, ao nível de 5\% para as médias de cada característica das respectivas populações, segundo a metodologia dada por STEEL \& TORRIE (1960):

$$
\text { I.C. }=\bar{x} \pm t s_{\bar{x}} \text {, }
$$

onde:

$\overline{\mathrm{x}}$ = a média observada para cada carāter;

$t=$ valor tabelado de acordo com os graus de liberdade referente ao resíduo da anālise de variância

$s_{\bar{x}}=$ erro padrão da média $=\widehat{\sigma}_{e}^{2} / r$, sendo

$\sigma_{\mathrm{e}}^{2}=$ estimativa da variância do erro experimental (análise de variân cia);

$\mathrm{r}=$ número de repetições

A precisão das estimativas dos componentes da variância $\hat{\sigma}_{\mathrm{p}}^{2}, \hat{\sigma}_{\mathrm{e}}^{2}$, $\widehat{\sigma}_{\mathrm{d}}^{2}$ e $\hat{\sigma}_{\mathrm{A}}^{2}$, foram calculadas conforme a metodologia utilizada por VELLO \& VENCOVSKY (1974) e FERREIRA (1986).

$$
\begin{aligned}
& \hat{\mathrm{s}}\left(\widehat{\sigma}_{\mathrm{p}}^{2}\right)=\left[\frac{2}{\mathrm{k}^{2} \mathrm{r}}\left(\frac{\mathrm{Q}_{1}^{2}}{\left(\mathrm{~g}_{1}+2\right)}+\frac{\mathrm{Q}_{2}^{2}}{\left(\mathrm{~g}_{2}+2\right)}\right)\right]^{1 / 2} \\
& \hat{\mathrm{s}}\left(\widehat{\sigma}_{\mathrm{e}}^{2}\right)=\left\{\frac{2}{\mathrm{k}^{2}} \cdot\left(\frac{\mathrm{Q}_{2}^{2}}{\left(\mathrm{~g}_{2}+2\right)}+\frac{\mathrm{Q}_{3}^{2}}{\left(\mathrm{~g}_{3}+2\right)}\right)\right]^{1 / 2} \\
& \hat{\mathrm{s}}\left(\hat{\sigma}_{\mathrm{e}^{\prime}}^{2}\right)=\left(\frac{2 Q_{2}^{2}}{\left(g_{2}+2\right)}\right)^{1 / 2}
\end{aligned}
$$




$$
\begin{aligned}
& \hat{\mathrm{S}}\left(\hat{\sigma}_{\mathrm{d}}^{2}\right)=\left(\frac{2 Q_{3}^{2}}{\left(g_{3}+2\right)}\right)^{1 / 2} \\
& \hat{\mathrm{S}}\left(\hat{\sigma}_{\mathrm{A}}^{2}\right)=4 \hat{\mathrm{S}}\left(\hat{\sigma}_{\mathrm{p}}^{2}\right)
\end{aligned}
$$

onde:

$\widehat{S}\left(\hat{\sigma}^{2}\right)$, corresponde à estimativa do desvio padrão da estimativa de variância. 
4. RESULTADOS E DISCUSSÃO

4.1. Médias Populacionais e Anālises de Variâncias

As médias fenotípicas das quinze características estudadas nas popullações Piranão VD-2-MI-0, Piranão VD-2-MI-AO, Piranão VF-1-MI-0 e Piranão VF-1-MI-AO, são apresentadas nas tabelas 3 e 4 . Os referidos valores encontram-se acompanhados pelos respectivos intervalos de confiança, destacando-se por sua magnitude os pertencentes ao rendimento, pela grande influência que tem o ambiente sobre este carāter.

A sequência dada anteriormente para as quatro populações em estudo, será a mesma usada para a discussão dos resultados obtidos, a fim de evitar a repetitividade de seus nomes.

Os resumos das respectivas anālises de variância e suas significâncias, acham-se nas tabelas 5 e 6, agrupando a primeira tabela as populações dentado e a segunda as populações flint.

Os valores médios para os caracteres altura da planta e altura da espiga (Tabelas 3 e 4), nas populações selecionadas para alto teor de óleo, foram divergentes com relação às médias das populações 
originais. Piranão VD-2-MI-A0, registrou decréscimos de 3,69 e 1,48\%, res pectivamente, enquanto que Piranão VF-1-MI-A0, apresentou acréscimos de 9,90 e 13,48\%. Não obstante, as populações dentadas foram superiores na altura da planta e na altura da espiga, em relação às populações flint. Estes valores estão em concordância com a informação obtida por BIANCO (1984) e contrasta com PATERNIANI et ali $i$ (1977), manifestando que as populações originais dentado e flint, apresentam quase as mesmas alturas da planta e da espiga.

Decréscimos na altura da planta e altura da espiga foram relatados por MISEVIC \& ALEXANDER (1989), em outras populações, e eles consideraram a endogamia como a responsável por estas reduções, enquanto que BIANCO (1984), em populações semelhantes à desta pesquisa, encontrou correlações genéticas aditivas negativas entre a porcentagem de óleo e as características antes mencionadas.

A razão para a diminuição da altura da planta e espiga na população Piranão VD-2-MI-A0, pode ser explicada pelas alterações nas cor relações genéticas aditivas entre a porcentagem de óleo e estas caracterỉsticas, por quebra de blocos gênicos, que tornaram-se negativas (Tabela 22). Para a população Piranão VF-1-MI-A0, o aumento da altura da planta e espiga, pode estar sustentado pela utilização de progênies com menor grau de associação entre estas características, já que seus valores estão próximos a zero (Tabela 23).

As análises de variância para estas duas características, registraram diferenças altamente significativas entre as progênies de cada população, o qual è um indicativo do potencial genético existente em cada população, situação que permite que elas possam ser melhoradas, segundo os objetivos do programa de melhoramento. 
Os valores relativos aos coeficientes de variação

experimental pertinentes à altura da planta, foram de 6,$11 ; 7,07 ; \quad 7,73$ e $8,91 \%$, enquanto que para a altura da espiga, foram de 7,$69 ; 9,11 ; 10,11$ e 11,67\% (Tabelas 5 e 6). Estes valores encontram-se dentro da faixa de registros da literatura consultada e de magnitudes razoáveis na experimentação agronômica. TOSELLO \& GERALDI (1980b) relataram 6,15 e 9,33\% para a variedade ESALQ-VD-opaco, BIANCO (1984) de 5,64 e 11,26\% para o Piranão VD e 7,45 e $12,31 \%$ no Piranão VF; ZIMBACK (1985) de 7,34 e $11,68 \%$ e 6,97 e $10,46 \%$ nas subpopulações A e B na variedade Dentado Braquítico 0paco, e SOARES (1987) de 7,82 e 11,50\% para o Piranão VD-2-B e 8,46 e 11,68\% para o Piranão VF-1-B, para a altura da planta e espiga, verificando-se a existência de maior variação para a altura da espiga em relação à altura da planta, tanto nos resultados deste estudo como na informação da literatura.

Os valores médios para o rendimento (g/planta), foram de 166,$21 ; 155,45 ; 123,41$ e 144,40 (Tabelas 3 e 4), respectivamente para as quatro populações em estudo. Registrando-se uma redução no rendimento de $6,47 \%$ na população Piranão VD-2-MI-AO em relação à média da população Piranão VD-2-MI-0, entretanto Piranão VF-1-MI-AO, houve acréscimos de $17 \%$, em relação ao Piranão VF-1-MI-0.

Decréscimos no rendimento tem sido reportados em outros experimentos realizados por DUDLEY et alii (1974) e MISEVIC \& ALEXANDER (1989), relatando os $\bar{u} 1 t i m o s$ pesquisadores que a redução do rendimento apös o quinto ciclo, pode ser explicada pela endogamia, devido a restri ções no tamanho da população; enquanto que nenhuma modificação neste 
carāter foi encontrado por RUSCHELL \& BAUMAN (1973) e MILLER et alii (1981). A este respeito, eles manifestaram que a estabilidade no rendimento foi conseguida por ter trabalhado com maior tamanho efetivo. A provável explicação da redução do rendimento, no Piranão VD-2-MI-AO, pode estar associado à alteração da composição química da semente (carbohidratos, proteỉnas e lipídeos), jā que o aumento da quantidade de óleo, al-tera as quantidades de proteínas e carbohidratos, diminuindo a quantidade de biomassa na semente como expressaram SINCLAIR \& DE WIT (1975); enquanto no Piranão VF-1-MI-AO, os acréscimos no rendimento desta população, parecem ajustar-se ao expressado por ALEXANDER \& LAMBERT (1968) e DUDLFi et alii (1974), que sugeriram que a capacidade de uma planta em produzir carbohidratos e sịntetizar óleo são completamente independentes atē o nível de $7 \%$ de aumento na porcentagem de óleo. Em populações selecionadas previamente para esta característica, segundo ALEXANDER \& SEIF (1963), ocorre aumento na porcentagem de óleo no embrião ou tamanho deste, sem causar redução do tamanho do endosperma, por ser mais eficiente na cap tação de energia.

As significâncias dos quadrados médios detectados através das análises de variância (Tabelas 5 e 6), mostraram a existência de variação entre as progênies de meios irmãos de cada uma das populações para o rendimento. Esta significância, nos fornece uma idéia do possível sucesso que poderá ser obtido para esta característica mediante o: melhoramento genētico.

Os coeficientes de variação experimental foram de 13,62; 14,$64 ; 23,23$ e 15,67\%, respectivamente para as quatro populações (Tabelas 5 e 6). Verifica-se que estes valores são satisfatórios, exceto 
$23,23 \%$, os quais se encaixam nos valores citados por TOSELLO \& GERALDI (1980b) de 14,40\%, SANTOS (1985) de 13,95; 15,34 e 15,06\%, ZIMBACK (1985) de 13,24 e $12,66 \%$ e TYAGI et alii (1988) de 10,87 e $15,89 \%$ e inferiores aos manifestados por MIRANDA et alii (1976) de 22,2, 18,5 e 21,0\% e BASSOI (1987) de 26,98\%. VENCOVSKY et alii (1988), relataram que a média dos coeficientes de variação de 58 ensaios com progênies de meios irmãos conduzidos no Brasil, foi de $16,30 \%$, oscilando de 7,8 a $23.30 \%$.

Para o diâmetro da espiga as médias das quatro populações foram 4,65, 4,47, 4,23 e 4,35cm/espiga (Tabelas 3 e 4). Constata-se a exis tência de modificações divergentes nas médias das populações com maior porcentagem de óleo, em relação às populações originais, registrando-se decréscimos de 3,87\% para o Piranão VD-2-MI-AO e acréscimos de 2,35\% para o Piranão VF-1-MI-A0.

Apesar da divergência nos resultados obtidos entre as populações dentado alto óleo e flint alto óleo, pode observar-que que os va lores médios do diâmetro da espiga foram inferiores nas duas populações flint em relação às duas populações dentado. A redução do diâmetro da espiga no dentado alto óleo, foi acompanhada por redução no tamanho do grão, possivelmente porque a seleção aumentou o tamanho do embrião, reduzindo o tamanho do endosperma. WOODWORTH et alii (1952), também constataram esta alteração morfolögica em populações de alto conteúdo de óleo. A provāvel razão para o aumento do diâmetro da espiga no flint alto óleo, está fundamentada no menor ganho na porcentagem de óleo e alongamentos no perỉodo de enchimento de grãos e acumulação de matéria seca jã que a atividade mitótica no endosperma possivelmente foi alterada favorecendo maior nưmero de células em relação à população original, que em conseqüência per mite a obtenção de grãos de maior tamanho segundo CAPITANIO et alii (1983). 
Os valores e significância dos quadrados médios obtidos nas análises de variância para o diâmetro da espiga, são mostrados nas tabelas 5 e 6 , podendo-se verificar diferenças altamente significativas entre as progênies de cada população.

Os coeficientes de variação experimental foram de 4,08; 3,$93 ; 4,47$ e 4,47\%, podendo ser considerados de boa precisão na experimentação agronômica (Tabelas 5 e 6 ), e inferiores aos fornecidos por SANTOS $(1985)$ de 4,$21 ; 5,73 ; 5,67 \%$, respectivamente para três populações e SOARES (1987) de 6,45 e 7,72\% para duas populações.

Para o carāter comprimento da espiga, as médias das quatro populações foram 16,$77 ; 16,92 ; 17,68$ e $17,45 \mathrm{~cm}$ (Tabelas 3 e 4 ). Verifica-se que a média das populações selecionadas para maior porcentagem de óleo, apresentou resposta divergente, registrando-se aumento de 0,89\% para o Piranão VD-2-MI-AO e redução de 1,30\% para o Piranão VF-1-MI-AO. A redução deste caráter para a população flint de alto óleo, concorda com os resultados obtidos por WOODWORTH et alii (1952) e MISEVIC \& ALEXANDER (1989), em populações de alto conteúdo de óleo, o qual pode estar sustentado pela existência de associação negativa entre estas características expressada por MISEVIC \& ALEXANDER (1989) e corroborada nas populações flint de acordo com os resultados do presente trabalho (Tabela 25).

Constata-se efeito altamente significativo para o comprimento da espiga nas quatro populações (Tabelas 5 e 6 ), o que verifica a existência de variação entre as progênies de cada população, o qual permite que elas possam ser melhoradas, principalmente as populações flint. 
Os coeficientes de variação experimental foram

6,$51 ; 6,37$ e $8,00 \%$, respectivamente para as quatro populações (Tabelas 5 e 6). Estes valores mostraram ser de maior precisão quando comparados com os resultados relatados por GALAL et alii (1977) de 9,90 e 11,90\%, SANTOS (1985) de 7,16;7,93 e 7,80\%, SHEATA et alii (1987b) de 8,00 e 8,80\% e TYAGI et alii (1988) de 12,57 e 12,03\%.

As médias fenotípicas para o carāter número de fileiras foram de 12,$97 ; 13,01 ; 13,30$ e $1.3,40 \mathrm{nf} /$ espiga (Tabelas 3 e 4 ), respectivamente para as quatro populações. Baseando-se nos resultados apresentados, nota-se que as populações de maior porcentagem de óleo registraram o mesmo comportamento, uma vez que obtiveram aumentos de 0,30 e 0,75\% para o Piranão VD-2-MI-AO e Piranão VF-1-MI-AO, os quais são de pouca monta.

Os valores e significâncias dos quadrados médios relativos ao carāter número de filleiras; são apresentados nas tabelas 5 e 6 . Nota-se que houve diferenças altamente significativas para cada população, -o que permite que este caráter possa ser melhorado geneticamente.

Os coeficientes de variação experimental foram de 5,82; 6,$28 ; 6,35$ e 6,61\%, podendo-se perceber que os coeficientes não apresentaram variação de grande magnitude em cada uma das populações em estudo (Tabelas 5 e 6). Estes coeficientes foram próximos aos fornecidos por GALAL et alii (1977) de 6,90 e 7,90\%, SANTOS (1985) de 4,59;6,49 e 6,02\%, SHEATA et alii (1987a), de 6,70 e 6,90\% e inferiores aos relatados por EL-ROUBY et alii (1979a) de 10,00 e 9,00\% e TYAGI et alii (1988) de 7,93 e 13,29\%. 
Comparando-se os valores médios obtidos para o caräter nümero de grãos por fileira (ngf/espiga), nas populações dentado e flint (Tabelas 3 e 4 ), verifica-se que houve uma redução de $2,10 \%$ no Piranão VD-2-MI-AO, jā que sua média foi de 35,73 em relação a 36,50 da população original; enquanto que no Piranão VF-1-MI-AO, houve um aumento de $1,16 \%$, dado que seu valor médio foi de 32,92 em relação a 32,50 da população original. Esta discrepância na resposta das populações dentado e flint à seleção para maior porcentagem de óleo na semente, pode explicar em parte a divergência no rendimento das populações melhoradas para conteúdo de óleo. ORTIZ et alii (1984), relataram modificações no rendimento da variedade $\mathrm{Zac}-58$, após a seleção por alterações no nümero de grãos por fileiras, enquanto que MISEVIC \& ALEXANDER (1989), cons tataram que a seleção para maior porcentagem de óleo, levou a aumentos no número de grãos por fileira, argumentando desconhecer as razões explicativas para este fato.

Os valores e significâncias dos quadrados médios das anālises de variância para o número de grãos por fileira, acham-se nas tabelas 5 e 6 . Estes valores mostraram-se altamente significativos, indicando a presença de variabilidade genética entre progênies para cada população, apresentando maior variabilidade as populações flint.

Os coeficientes de variação experimental do caráter número de grãos por fileira, foram de 9,02; 9,45; 10,19 e 12,04\% (T'abelas 5 e 6). Estes valores podem ser considerados razoáveis, jā que foram inferiores aos fornecidos por GALAL et alii (1977) de 11,90 e 14,40\%, SHEATA et alii (1987a) de 15,10 e 11,50\% e TYAGI et alii (1988) de 14,00 e $11,87 \%$, enquanto que superiores aos encontrados por SANTOS (1985) de 
9,$62 ; 8,94$ e $8,40 \%$ e SHEATA et alii (1987b) de 7,40 e 7,50\%.

Para o carāter comprimento de grãos, os valores médios foram de 1,$03 ; 0,93 ; 0,75$ e $0,81 \mathrm{~cm}$ (Tabelas 3 e 4 ). Observa-se que houve redução de $9,70 \%$ para o Piranão VD-2-MI-AO e aumento de $8,00 \%$ para o Piranão VF-1-MI-AO. Não obstante, os grãos das populações flint serem mais pequenos que os dentados, os resultados concordam com WOODWORTH et alii (1952) que encontraram grãos mais pequenos nas populações de maior porcentagem de óleo, o que segundo REDDY \& DAYNARD (1983), parece estar afetado pela redução no tamanho dos grânulos de amido nas células do endosperma, em razão do aumento do conteúdo de óleo no embrião, já que segundo PENNING DE VRIES et alii (1974) e RAMAN et alii (1983), a quan tidade de açūcar necessária para produzir lg de lipídeos é duas vezes maior que a de $1 \mathrm{~g}$ de carbohidrato e uma caloria de óleo pesa aproximadamente $40 \%$ de uma caloria de carbohidrato. 0 aumento deste carāter nà população Piranão VF-1-MI-AO, possivelmente esteja associado a alongamentos no periodo de enchimento de grãos, levando a maior acumulação de matéria seca, durante o desenvolvimento do grão, de acordo com o expressado por CROSBIE \& MOCK (1981). Estes resultados, podem ajudar a explicar em parte as divergências encontradas nas populações em estudo para o diâmetro da espiga e rendimento.

Para as quatro populações, os valores médios obtidos nas análises de variância para o comprimento de grãos, registraram diferenças altamente significativas entre progênies de meios irmãos, indicando uma maior variação para as populações flint (Tabelas 5 e 6). 
Os coeficientes de variação pertencentes ao comprimento de grãos, foram de 7,$83 ; 6,99 ; 9,90$ e 9,90\% respectivamente para as quatro populações (Tabelas 5 e 6 ), podendo-se perceber que estes valores não apresentaram variação de grande magnitude entre as populações, sendo superiores aos obtidos por WEIGEL (1978) de 3,22 e 3,51\%.

Para o carāter largura de grãos, os valores das populações foram de 1,$01 ; 0,96 ; 0,89$ e $0,91 \mathrm{~cm}$ (Tabelas 3 e 4 ). Nota-se que aconteceram decréscimos de 4,95\% para o Piranão VD-2-MI-AO e acréscimos de 2,24\% para o Piranão VF-1-MI-A0. Estes resultados combinados com os de comprimento de grãos, levaram o Piranão VD-2-MI-AO a conter grãos menores que a população original, como resposta ao aumento na porcentagem deóleo na semente. MILLER et alii (1981), manifestaram que os aumentos no con teúdo de óleo, podem levar a redução no tamanho do grão e consequentemente no rendimento, pelas possíveis limitações bioenergéticas para aumentar a porcentagem de óleo, que afetam a quantidade de carbohidratos na semente.

No que concerne aos quadrados médios das anālises de variância, estes mostraram diferenças altamente significativas para cada uma das populações, evidenciando a existência de variação entre progênies de meios irmãos (Tabelas 5 e 6 ).

A precisão experimental dos ensaios pode ser considerada boa, tendo em vista que os coeficientes de variação experimental obtidos foram baixos, 5,$71 ; 5,69 ; 6,23$ e 5,56\%, e de pouca variação entre os qua tro experimentos ( $T$ abelas 5 e 6 ), sendo superiores aos expressados por WEIGEL (1978) de 2,70 e 2,94\%. 
Quanto ao peso de 100 grãos, os valores médios foram de 34,$28 ; 32,45 ; 30,53$ e 31,45 gramas (Tabelas 3 e 4). Verifica-se que a popu lação Piranão VD-2-MI-AO registrou uma redução de 5,33\%, enquanto que $P \underline{i}$ ranão VF-1-MI-A0, acréscimos de 3,01\% em relação às populações originais. MILLER et alii (1981) e MISEVIC \& ALEXANDER (1989), encontraram resposta semelhante como consequência da seleção para maior porcentagem de óleo. A divergência na resposta das populações de alto óleo, possivelmente obe deça aos ganhos conseguidos no conteúdo deóleo que foram de maior magnitude para o Piranão VD-2-MI-AO do que Piranão VF-1-MI-AO (Tabelas 3 e 4).

Os resultados apresentados nas análises de variância, mos traram diferenças altamente significativas nas quatro populações, indicando a existência de maior variação para a população Piranão VF-1-MI-AO em relação à população Piranão VD-2-MI-AO (Tabelas 5 e 6).

Os coeficientes de variação experimental obtidos foram de 8,$49 ; 9,42 ; 8,73$ e $8,78 \%$ (Tabelas 5 e 6 ). São bastante razoáveis dentro da experimentação agronômica. Os valores são parecidos àqueles relatados por QUEIROZ (1969) de 8,85 e 9,25\%; WEIGEL (1978) de 8,34\% e EL-ROUBY et alii (1979a.b) de 7,00; 9,00 e 9,00\%, inferiores aos citados por ELROUBY et alii (1973) de 12,80 e 14,30\%; SHEATA et alii (1987a.b.) de 11,$80 ; 10,80 ; 18,20$ e $16,90 \%$ e TYAGI et alii (1988) de 10,64 e 9,98\% e superiores aos de TOSELLO E GERALDI (1980b) de 6,96\% e ZIMBACK de 7,61 e $7,73 \%$.

Os valores médios do peso de grãos foram de 165,13; 146,$45 ; 125,46$ e 134,55 gramas/espiga (Tabelas 3 e 4), respectivamente pa ra as quatro populações. Nota-se que a seleção para maior porcentagem 
de óleo, originou redução no peso de grãos do Piranão VD-2-MI-AO, em $11,31 \%$ e acréscimos de $7,25 \%$ para a população Piranão VF-1-MI-A0, em relação às populações originais, o que è um reflexo do sucedido no peso de 100 grãos e rendimento. Os decréscimos no peso de grãos para o Piranão VD-2-MI-AO, além da possíve1 endogamia manifestada por MISEVIC \& ALEXANDER (1989), pode estar associada a modificações no tamanho do endosperma, como consequência do aumento no tamanho do embrião, pelos ganhos obtidos no conteúdo de óleo. Entretanto para o Piranão VF-1-MI-A0, o aumento do peso de grãos parece encaixar no expressado por MILLER \& BRIMHALL (1951) e DUDLEY et alii (1974), manifestando que podem ser obtidos aumentos no teor de óleo sem causar decréscimos no rendimento, especialmente quando a seleção não atinge uma porcentagem de $7 \%$. Por outro lado ALEXANDER \& SEIF (1963), disseram que a redução no tamanho do endosperma não é uma resposta universal como consequências dos aumentos nos conteūdos de óleo.

Os quadrados médios das anālises de variância acusaram ausência de significância para a população Piranão VD-2-MI-0, 'enquanto que as demais populações revelaram significância ao nível de 1\%, indicando a existência de variabilidade genética considerável nestas populações (Tabelas 5 e 6). A falta de significância entre progênies na população Piranão VD-2-MI-O para este carāter e significância na mesma população para o rendimento, possivelmente obedeça a representatividade das amostras dentro de parcelas, dado que as amostras concernentes ao peso de grãos, apresentam um tamanho pequeno ( $K^{\prime} \leq 5$ espigas), em confronto com o daquelas pertinentes ao rendimento ( $K=$ stand ideal). 
Os valores relativos aos coeficientes de variação experimental, foram de 14,$19 ; 14,01 ; 15,91$ e $17,48 \%$, os quais foram 1igeiramente superiores aos fornecidos por QUEIROZ (1969) de 12,40 e 12,51\% e EL-ROUBY et alii (1979b) de 15,5\% e inferiores aos reportados por ELROUBY et alii (1979a), de 18,00 e 20,00\%; SANTOS (1985) de 16,16; 17,42 e $16,52 \%$ e SOARES (1987) de $24,00 \%$.

As médias fenotípicas para o carāter diâmetro do sabugo foram de 2,$58 ; 2,60 ; 2,72$ e $2,73 \mathrm{~cm}$ (Tabelas 3 e 4 ). Pode verificar-se que o efeito da seleção para aumentar o conteúdo de óleo na semente, não registrou nenhum efeito significativo nas médias das populações em estudo, possivelmente uma pobre associação biológica entre a porcentagem de óleo e esta característica, seja responsảvel por este fato, pelo registrado nas correlações obtidas, principalmente nas populações flint (Tabela 25).

Com relação aos valores e significâncias dos quadrados médios das análises de variância, estes revelaram diferenças altamente significativas para cada população em estudo, indicando a existência de variabilidade genética, o que permite a possibilidade de sucesso em escolher progênies dentro de cada população, de acordo com o objetivo do programa de melhoramento (Tabelas 5 e 6 ).

Os coeficientes de variação experimental obtidos, podem ser considerados baixos na experimentação agronômica, jâ que os valores registrados foram de 4,$13 ; 4,18 ; 4,62$ e 4,19\%, respectivamente para as quatro populações (Tabelas 5 e 6). Estudos apresentados por SANTOS (1985), forneceram coeficientes de 4,65; 5,34 e 4,92\%, enquanto que 
SOARES (1987), valores de 4,06 e 5,22\%, os quais são semelhantes aos obtidos nesta pesquisa.

Os valores médios para o caráter peso do sabugo, foram de 28,$01 ; 28,54 ; 27,96$ e 28,55 gramas (Tabelas 3 e 4), registrando as populações comportamento semelhante ao diâmetro do sabugo, jā que praticamente não sofreram modificações abruptas devido à seleção, em razão dis so as alterações registradas foram de 1,89 e 2,11\% para o Piranão VD-2-MI-AO e Piranão VF-1-MI-AO, em relação às populações originais.

Os quadrados médios das análises de variância mostraram diferenças altamente si.gnificativas para as quatro populações, indicando a presença de variabilidade genética entre as famílias de meios irmãos de cada população, mostrando maior variabilidade as progênies flint em relação às dentado (Tabelas 5 e 6).

Os coeficientes de variação experimental encontrados foram de 13,$95 ; 13,73 ; 14,77$ e $16,03 \%$, os quais na experimentação agronômica, são um tanto altos e ligeiramente superiores aos fornecidos por WEIGEL (1978) de 11,$11 ; 9,37$ e 10,25\%,

Em termos de médias, os valores da densidade dos grãos, foram de 1,$24 ; 1,22 ; 1,30$ e 1,29 gramas $/ \mathrm{cm}^{3}$ (Tabelas 3 e 4), constatando-se a tendência em reduzir a densidade dos grãos por efeitos da seleção para aumentar o conteūdo de óleo na semente, o que também foi verificado por BATISTA \& TOSELLO (1987), quando avaliaram duas populações contrastantes para porcentagem de óleo, provenientes do composto 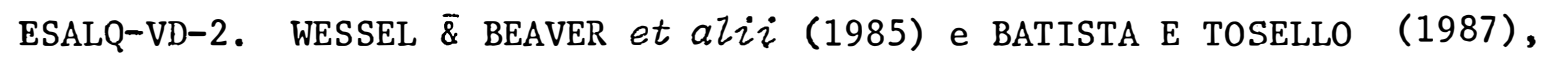 apontaram que o decréscimo na densidade dos grãos, deve-se ao fato de 
aumentar o volume dos grãos, em certas famílias por modificações no endosperma.

As anālises de variância referentes às determinações da densidade dos grãos, para as referidas populações, são apresentadas nas tabelas 5 e 6, onde as populações dentado original e flint alto óleo, acusaram ausência de significância entre as progênies de cada população, o qual indica a existência de pouca variabilidade genética nas famílias avaliadas. Estes resultados concordam com os obtidos por ZIMBACK (1985), em duas subpopulações dentado; enquanto que significância ao nível de 5\% foi detectada para as populações dentado alto óleo e flint original, evidenciando a presença de variabilidade genética em cada população. Resultados similares foram relatados por TOSELLO \& GERALDI (1980b).

Os coeficientes de variação experimental para a densidade dos grãos, podem ser considerados bons, indicando que os ensaios apresentaram boas precisões. Estes valores foram de 3,$07 ; 4,00 ; 2,31$ e $2,43 \%$ (Tabelas 5 e 6), que são bastante próximos aos fornecidos por TOSELLO \& GERALDI (1980b) de 3,24\%, BATISTA (1980) de 2,7 e 3,9\% e ZIMBACK (1985) de 4,12 e $3,01 \%$.

Tal como foi evidenciado por outros pesquisadores, a seleção recorrente foi eficiente para elevar a porcentagem de óleo nas populações dentado e flint. Os valores médios foram de 4,43; 5,37; 5,29 e 6,00\%, respectivamente para o Piranão VE-2-MI-0, Piranão VD-2-MI-AO, Piranão VF-1-MI-O e Piranão VF-1-MI-AO (Tabelas 3 e 4). Através desses valores, pode-se verificar que a população dentado aumentou em $21,21 \%$ e a população flint em $13,42 \%$. E muito provāvel que as duas populações 
com maior porcentagem de óleo, contrastem no mecanismo fisiológico para elevar o conteúdo de óleo, possivelmente no Piranão VD-2-MI-AO, devido a um aumento no tamanho do embrião, afetando o tamanho do grão, peso do grão e portanto, o rendimento; enquanto que para o Piranão VF-1-MI-AO, por aumento na porcentagem de óleo e/ou aumento no tamanho do embrião, talvez por maior período de enchimento do grão, o que permite o melhoramento simultâneo do conteúdo de óleo e rendimento até os limites de 7\%, expressados por DUDLEY et alii (1974). BIANCO (1984), em estudos realizados no Departamento de Genética da ESALQ, também encontrou maior teor de óleo na população Piranão VF-1 comparada à população Piranão VD-2.

Os valores e significâncias dos quadrados médios para a porcentagem de óleo, mostraram diferenças altamente significativas, para cada uma das populações, indicando a existência de variabilidade genética. para o carāter em questão, principalmente na população dentado alto óleo em relação à flint alto óleo (Tabelas 5 e 6), verificando-se que estas populações podem seguir sendo melhoradas, embora certas precauções devam ser tomadas para evitar queda no rendimento.

Os valores pertinentes aos coeficientes de variação experimental, para a porcentagem de óleo, foram de magnitudes razoáveis na experimentação agronômica, 9,73;9,80;10,41 e 9,26\% respectivamente para as quatro populações (Tabelas 5 e 6). Estes valores foram baixos quando comparados com os fornecidos por TOSELLO \& GERALDI (1980b) de $16,47 \%$, ZIMBACK (1985) de 17,83 e $19,20 \%$ e ZANOTTO (1986), de 21,23 e $14,74 \%$ e superiores aos obtidos por RUSCHELL \& BAUMAN (1973) de 4,39\% e BATISTA (1980) de 7,85 e 7,76\%. 
4.2. Estimativas dos Parâmetros Genéticos e Fenotípicos

4.2.2. Estimativas para os caracteres: altura da planta e altura da espiga

As estimativas das variâncias genéticas, ambientais e fenotípicas obtidas a partir dos quadrados médios para os caracteres altura da planta e altura da espiga das quatro populações acham-se nas tabelas 8, 9, 10 e 11. Todas as estimativas com exceção das variâncias fenotípicas, tem indicado o valor do desvio padrão, bem como o porcentual da estimativa que ele representa, caracterizando a precisão dos dados. Os coeficientes de herdabilidade no sentido restrito, ao nível de médias $\left(\widehat{\mathrm{h}}_{\mathrm{m}}^{2}\right)$, coeficiente de variação genética $\left(\mathrm{CV}_{\mathrm{g}} \%\right)$ e Índice de variação das populações em estudo estão contidos nas tabelas 12 e 13 .

Para o caräter altura da planta as estimativas da variância genética aditiva foram de $4183,846 \times 10^{-5} ; 4465,882 \times 10^{-5} ; 2186,825 \times 10^{-5}$ e $11239,884 \times 10^{-5}(\mathrm{~m} / \mathrm{p} 1 \mathrm{anta})^{2}$ e para o carāter altura da espiga estas estimativas foram de $2358,875 \times 10^{-5} ; \quad 2598,227 \times 10^{-5} ; \quad 1499,193 \times 10^{-5}$ e $6672,930 \times 10^{-5}(\mathrm{~m} / \mathrm{planta})^{2}$, respectivamente para o Piranão VD-2-MI-0, Piranão VD-2-MI-AO, Piranão VF-1-MI-O e Piranão VF-1-MI-AO (Tabelas 8, 9, 10 e 11). Observa-se que nas quatro populações as estimativas da variância genética aditiva $\left(\hat{\sigma}_{\mathrm{A}}^{2}\right)$, foi de maior magnitude para a altura da planta que para a altura da espiga. Resultados semelhantes foram obtidos por ELROLBBY \& PENNY (1967), TOSELLO \& GERALDI (1980b), SOUZA JUNIOR (1983), BIANCO (1984), ZIMBACK (1985), SANTOS (1985), NAWAR (1986), SOARES (1987) e LEMOS et alii (1990). 
Comparando-se as estimativas da variância genética aditiva para estas duas características nas populações de alto óleo em relação às populações originais, verifica-se que estas magnitudes foram inferiores nas populações originais, mostrando que as populações diferem consideravelmente quanto a variabilidade genética, e que são promisso ras para o melhoramento intrapopulacional.

Os coeficientes de variação genética para a altura da plan ta foram de 5,$25 ; 5,63 ; 4,43$ e 9,13\%, enquanto que para os indices de variação b, foram de 0,$85 ; 0,79 ; 0,57$ e 1,02 . Para a altura da espiga, estes coeficientes de variação genética foram de 7,$17 ; 7,61 ; 6,80$ e 12,66\%, sendo os Indices de variação b de 0,$93 ; 0,83 ; 0,67$ e 1,08 (Tabelas 12 e 13). Verifica-se novamente a existência de variabilidade genética livre nas quatro populações, principalmente para o caráter altura da espiga, resultados que concordam com os relatados por BIANCO (1984), SANTOS (1985), ZIMBACK (1985), ZANOTTO (1986) SOARES (1987) e LEMOS et alii (1990).

As estimativas,para os coeficientes de herdabilidade aos níveis de média $\left(\hat{\mathrm{h}}_{\mathrm{m}}^{2}\right)$ para a altura da planta foram de 68,$86 ; 65,57 ; 49,59$ e 75,90\% e para altura da espiga 72,09; 67,64; 57,59 e 77,91\% (Tabelas 12 e 13). Constata-se que a herdabilidade para a altura da espiga foi maior que para a altura da planta, o que é um reflexo da existência de maior va riabilidade genética. Estes concordam com os relatados por HALLAUER \& MIRANDA FILHO (1982) de 66,20 e 56,90\%; SANTOS (1985) de 46,37 e 44,33\%; ZIMBACK (1985) de 51,67 e 49,70\% e 62,40 e 60,72\%, para duas subpopulações da variedade Dentado Braquítico Opaco; ZANOTTO (1986) de 21,01 e $15,86 \%$ e 37,16 e $29,17 \%$ para duas populações flint, contrastantes na porcentagem de óleo; SOARES (1987) de 63,71 e 60,42\% e LEMOS et alii (1990) 
de 56,15 e $40,65 \%$.

Considerando por outro 1ado, a faixa de variação (50 a 70\%), para as estimativas dos coeficientes de herdabilidade, conforme propuseram HALLAUER \& MIRANDA FILHO (1982), verifica-se que as estimativas obtidas estão dentro desta amplitude de variação, exceto a população flint de alto óleo, que tem valores acima de $70 \%$.

Os resultados dos progressos genéticos esperados por ciclo de seleção entre famílias de meios irmãos, um ciclo a cada dois anos, uti lizando sementes remanescentes e uma intensidade de seleção de $10 \%$ entre famílias, estão nas tabelas 14 e 15. Os ganhos genéticos esperados para o carāter altura da planta são de 7,$64 ; 8,00 ; 5,47$ e 13,96\%, enquanto que para a altura da espiga 10,$69 ; 10,98 ; 9,06$ e $19,61 \%$, respectivamente para as quatro populações, os quais são considerados bons, dada as magnitudes da variabilidade genética 1iv̛re; principalmente para a altura da espịga.

\subsubsection{Estimativas para o carāter rendimento}

Observando-se as estimativas das variâncias genéticas aditivas, para o rendimento (gramas/planta) ${ }^{2}$ obtidas para cada população (Tabela 7), verifica-se que as populações flint, Piranão VF-1-MI-0 $(824,3238)$ e Piranão VF-1-MI-AQ $(523,5163)$, foram de maior magnitude com respeito às populações dentado, Piranão VD-2-MI-0 $(545,0547)$ e Piranão VD-2-MI-AO $(409,7222)$. Resultados desta natureza também foram mostrados por PATERNIANI (1968), LIMA (1977), SANTOS \& NASPOLINI FILHO (1986) e CANTON (1988), evidenciando que a mais drāstica redução da variabilidade genética ocorreu no Piranão VF-1-MI-AO, o que segundo VENCOVSKY (1987), 
é devido à fixação de grande parte dos alelos favoráveis ou superestimação pela interação genótipo $\mathrm{x}$ ambiente de acordo com HALLAUER \& MIRANDA FILHO (1982), por ser fator limitante em sua estimação real.

As estimativas dos coeficientes de variação genética para as quatro populações, referentes ao rendimento foram de 7,$02 ; 6,51 ; 11,63$ e 7,92\%, enquanto que seus índices de variação b de 0,$51 ; 0,44 ; 0,50$ e 0,50 (Tabelas 12 e 13), constatando-se inconsistência na relação dos coeficientes de variação genética, Indice de variação b e estimativas da variância genética aditiva para a população Piranão VF-1-MI-0, o qual possivelmente obedeçe à precisão experimental deste ensaio, que registrou $\mathrm{CV}_{\mathrm{e}}$ de $23,23 \%$. SANTOS \& NASPOLINI FILHO (1986), obtiveram resultados similares.

Considerando os valores dos índices de variação b deste trabalho, pode-se constatar a existência de níveis razoáveis de variabilidade genética, jā que segundo VENCOVSKY (1987) considera que estimativas do índice b próximas de 1 , são bastante favoráveis à seleção e com grandes possibilidades de sucesso. Os resultados da presente pesquisa, são bastante semelhantes aos relatados por TOSELLO \& GERALDI (1980b) de 0,41; SANTOS (1985) de 0,$31 ; 0,35$ e 0,55; SAMPAIO (1986) de 0,60 e 0,45; SANTOS \& NASPOLINI FILHO (1986) de 0,39;0,38;0,31 e 0,30; BIGOTO (1988) de 0,42; CANTON (1988) de 0,51 e LEMOS et alii (1990) de 0,44, entretanto são inferiores aos citados por BIANCO (1984) de 0,96 e 0,88 e ZIMBACK (1985) de 0,63 e 0,68. Conforme manifestaram VENCOVSKY et alii (1988), os valores médios em programas brasileiros são de 0,45 , evidenciando as possibilidades para obter progressos para este caráter nas quatro populações em estudo. 
Para o coeficiente de herdabilidade no sentido restrito ao nível de médias $\left(\hat{\mathrm{h}}_{\mathrm{m}}^{2}\right)$, as estimativas obtidas foram de 44,35; 37,20;42,91 e 43,48\% (Tabelas 12 e 13), valores estes superiores aos apresentados por TOSELLO \& GERALDI (1980b), SANTOS (1985) e SANTOS \& NASPOLINI FILHO (1986), próximos aos obtidos por ZIMBACK (1985) e BIGOTO (1988), enquanto que inferiores aos relatados por BIANCO (1984). Neste sentido as estimativas obtidas, estão acima do valor de $30 \%$, proposto por HALLAUER \& MIRANDA FILHO (1982).

Os resutlados do ganho genético esperado para o rendimento acham-se nas tabelas 14 e 15 . podendo-se constatar a potencialidade das populações flint em relação às dentado, no referente à variabilidade genética. Os ganhos esperados por ciclo de seleção foram de 8,20;6,96; 13,37 e $9,17 \%$, respectivamente para as quatro populações.

$\therefore \quad$ 4.2.3. Estimativas para o caräter diâmetro da espiga

Os valores encontrados para as estimativas das variâncias genéticas aditivas das quatro populações foram $3581,714 \times 10^{-5}, 2837,621 \times 10^{-5}$, $7944,024 \times 10^{-5}$ e $6056,3 \times 10^{-5}(\mathrm{~cm} / \text { espiga })^{2}$, verificando-se que as populações flint foram superiores às dentado (Tabelas 8, 9, 10 e 11), fato este que também foi evidenciado por SOARES (1987), que encontrou magnitudes de $89,1848 \times 10^{-3}$ e $59,7500 \times 10^{-3}$, nas populações Piranão VF-1-B e Piranão VD-2-B.

Para se ter uma idéia geral da variabilidade genética exis tente nas populações estudadas, as estimativas obtidas para as variâncias genéticas aditivas por GALAL et alii (1977), VARGAS (1982), SANTOS (1985), SOARES (1987), bem como a média de trinta e cinco estimativas fornecidas 
por HALLAUER \& MIRANDA FILHO (1982), foram superiores em relação às populações dentado e inferiores às flint, portanto, as Piranão VF-1-MI-0 e Piranão VF-1-MI-AO, têm maior potencial de melhoramento genético intrapopulacional.

Considerando os coeficientes de variação genética (Tabelas 12 e 13), as populações flint apresentaram valores mais elevados que as populações dentado, o qual evidencia a presença de maior variabilidade ge nética. No que se refere aos índices de variação b (Tabelas 12 e 13), es tas mostraram-se de maior magnitude nas Piranão VF-1-MI-0 e Piranão VF-1-MI-AO, em relação as Piranão VD-2-MI-O e Piranão VD-2-MI-AO, o qual verifica as maiores possibilidades de sucesso para o caráter em questão nas populações flint em relação as dentado.

As magnitudes relativas aos coeficientes de herdabilidade no sentido restrito ao nível de plantas $\left(\hat{h}_{i}^{2}\right)$ e ao nível de médias $\left(\widehat{h}_{\mathrm{m}}^{2}\right)$ acham-se nas tabelas 12 e 13, verifica-se que estas magnitudes foram semelhantes nas populações do mesmo tipo de grão, evidenciando que o melhoramento deste caráter deve ser feito através de métodos de seleção associados com um melhor controle das condições ambientais, como aqueles que se fundamentam em testes de progênies.

Com relação as estimativas dos progressos genéticos esperados com a seleção entre e dentro de famílias de meios irmãos (Tabelas 16 e 17), pode-se observar que os ganhos foram praticamente duas vezes maiores nas populações flint, em relação às populações dentado. 
4.2.4. Estimativas para o caráter comprimento da espiga As estimativas da variância genética aditiva (cm/espiga) ${ }^{2}$ para as quatro populações, acham-se nas tabelas $8,9,10$ e 11 . Pode-se constatar que as populações de alto óleo sofreram acréscimos e reduções nas estimativas em relação às populações originais, pela alteração das freqüências de genes favoráveis e não favorāveis, por efeitos da seleção.

As estimativas aqui obtidas, foram superiores aos valores médios de 36 estimativas apresentadas por HALLAUER \& MIRANDA FILHO (1982) e aos resultados obtidos por GALAL et alii (1977) e SANTOS (1985). E de se notar que estas comparações são limitadas pelas interações genótipos $\mathrm{x}$ anos e/ou genótipos $\mathrm{x}$ ambiente, não obstante as populações em estudo, apresentarem quantidades razoáveis de variabilidade genética. .

Quanto aos coeficientes de variação genética e os indices de variação b (Tabelas 12 e 13), estes foram coerentes com os valores obtidos para as estimativas das variâncias genéticas aditivas, onde a popu1ação melhoràda Piranão VD-2-MI-AO, foi a de maior valor e variabilidade genética.

Os coeficientes de herdabilidade no sentido restrito ao nível de plantas $\left(\hat{\mathrm{h}}_{\hat{i}}^{2}\right)$ e ao nível de médias $\left(\hat{\mathrm{h}}_{\mathrm{m}}^{2}\right)$, das quatro populações, acham-se nas tabelas 12 e 13, verificando-se que a estimativa obtida para o Piranão VF-1-MI-A0, mostrou-se inferior em relação ao. Piranão VD-2-MI-AO, em virtude da menor variância genética aditiva detectada. Os valores obtidos estão muitas vezes acima e abaixo das médias do levantamento feito por HALLAUER \& MIRANDA FILHO (1982) de $38,10 \%$ e SANTOS (1985) 
de $36,58 \%$, enquanto que inferior ao fornecido por NAWAR (1986) de 73,00\%, para este carāter. Segundo Cortez-Mendoza-Hallauer citado por SANTOS (1985), o aumento da produção via seleção para comprimento da espiga, não é recomendável, uma vez que a seleção direta para produção foi $34 \%$ mais eficiente que através de seleção indireta, E de ressaltar que eles encontraram altos coeficientes de herdabilidade e uma boa correlação genética entre estes caracteres.

Os valores das estimativas de ganho genético, àcham-se nas tabelas 16 e 17, constatando-se uma superioridade nos ganhos obtidos pela população Piranão VD-2-MI-A0, em respeito ao Piranão VF-1-MI-A0, o que segundo Cortez-Mendoza-Hallauer citado por SANTOS (1985), pode levar a uma redução no comprimento do grão, pela existência de mudanças correlacịonadas da frequêencia de genes, como anotaram HALLAUER \& MIRANDA FILHO (1982).

4.2.5. Estimativas para os caracteres: nümero de fileiras e nūmero de grãos por fileira

Comparando-se os valores das estimativas das variâncias genéticas aditivas das populações originais em relação às populações de alto óleo (número de fileiras/espiga) ${ }^{2}$, pode-se constatar que houve uma redução deste parâmetro nas populações melhoradas para maior conteúdo de óleo (Tabelas 8, 9, 10 e 11), diminuindo consequentemente a variabilidade genética, por mudanças na freqüência daqueles genes que favorecem a expressão deste carāter.

Associando por outro lado, os valores deste estudo com os relatados por SANTOS (1985), as estimativas obtidas foram de menor 
magnitude às fornecidas por este pesquisador, em razão da introgressão de genes da raça cravo, nas populações melhoradas, a qual tem em média de zenove fileiras por espiga. De igual maneira os resultados aqui obtidos foram coerentes com os reportados por EL-ROUBY et alii (1973), GALAL et alii (1977) e VARGAS et alii (1982).

As estimativas das variâncias genéticas aditivas para o carāter número de grãos por fileira - (número de grãos/fileira), foram $942908,094 \times 10^{-5} ; 546696,000 \times 10^{-5} ; 2446042,00 \times 10^{-5}$ e $1122433,30 \times 10^{-5}$, respectivamente para as quatro populações, as quais estão contidas nas tabelas $8,9,10$ e 11. Pode-se apreciar que as populações flint apresentaram um valor mais alto que as dentado, da mesma maneira, redução em suas magnitudes nas populações de alto óleo em relação às populações origịnais, pela provāvel fixação de genes como anotaram WEBEL \& LONNQUIST (1967) e VENCOVSKY (1987).

Comparando-se estes resultados com os obtidos por GALAL et alii (1977), VARGAS (1982), SANTOS (1985) e SHEHATÁ et alii (1987) constatou-se a superioridade tanto das populações dentada como flint. Mes mo que as estimativas obtidas aqui estivessem distorcidas pelos efeitos da interação genótipo $x$ ambiente, elas fornecem uma idéia da potencialidade genētica destas populações.

A redução da variabilidade genética tanto para o número de fileiras como nümero de grãos por fileira nas populações de alto óleo den tado e flint, foi comprovada através dos coeficientes de variação genética e indices de variação b (Tabelas 12 e 13). Não obstante, ainda subsis te apreciāvel variabilidade genética, bem seja por aqueles genes não fixados ou por liberação de variabilidade genética potencial pela quebra 
de blocos gênicos através de recombinação.

Os valores encontrados para os coeficientes de herdabilidade no sentido restrito ao nível de plantas $\left(\hat{\mathrm{h}}_{\mathbf{i}}^{2}\right)$, para o número de fileiras foram superiores aos obtidos para o número de grãos/fileira, exceto para a população Piranão VF-1-MI-O (Tabelas 12 e 13). Resultados similares foram evidenciados por VARGAS et alii (1982) e SANTOS (1985), o que mostra que métodos simples de seleção podem proporcionar maiores progressos no nümero de fileiras.

As estimativas dos coeficientes de herdabilidade no sentido restrito ao nível de médias $\left(\widehat{h}_{\mathrm{m}}^{2}\right)$, apresentaram o mesmo comportamento que ao nível de planta. Os resultados aqui obtidos para o número de fileira foram próximos com a média do levantamento feito por SANTOS (1985) de $49,75 \%$ e ligeiramente inferiores com os dados obtidos em sua pesquisa de 67,40; 64, 24 e 51,59\% para trêsi populações, enquanto que para o nümero de grãos por fileira, foram mais baixos que a média de dezoito estimativas fornecidas por HALLAUER \& MIRANDA FILHO (1982) e compatíveis com os obtidos por SANTOS (1985).

Os ganhos genéticos esperados, praticando-se seleção entre e dentro de famílias de meios irmãos, tanto para o caráter número de fileîras como número de grãos por fileira, foram de menor magnitude nas populações de alto óleo, evidenciando a queda nas variâncias genéticas aditivas das populaçōes melhoradas (Tabelas 16 e 17). 
4.2.6. Estimativas para os caracteres: Comprimento de grãos Largura de gräos

Os valores das estimativas das variâncias genéticas aditivas para o comprimento de grãos (cm/grão $)^{2}$ acham-se nas tabelas 8, 9, 10 e 11. Pode observar-se que as populações de alto óleo apresentaram resposta divergente em seus valores, pelos efeitos da seleção sobre as freqüências gênicas iniciais, as quais possivelmente eram diferentes na fase inicial de seleção para alto teor de óleo.

Para ter uma idéia da variabilidade genétj.ca das populações estudadas, as estimativas obtidas para as variâncias genéticas aditivas das quatro populações, foi inferior à média de sete estimativas no levantamento feito por HALLAUER \& MIRANDA FILHO (1982) de 0,0187. Apesar das magnitudes das variâncias genéticas aditivas serem inferiores aos valores da literatura, ainda persiste determinada quantidade que possa ser utilizada no melhoramento deste carāter. Os resultados obtidos por LENG (1962) e ALEXANDER (1988), após 50 e 87 gerações de seleção para óleo e proteịna, demonstram que a variabilidade genética não foi esgotada, simplesmente que seus progressos foram menores, e tanto os caracteres dos grãos como a porcentagem de óleo são caracteres quantitativos.

No que concerne às estimativas das variâncias genéticas aditivas, para o carāter largura de grãos (cm/grão $)^{2}$, as quais estão contidas nas tabelas $8,9,10$ e 11, pode verificar-se que houve decrēscimos para a população dentado alto óleo e acréscimos para a população flint alto óleo, a qual pode haver acontecido pelas mesmas razões dadas para o carāter comprimento de grãos. 
Infelizmente a quantificação dos valores das estimativas das variâncias genéticas aditivas não foram comparadas com os obtidos por outros pesquisadores, por não encontrar informação a respeito no levantamento bibliográfico realizado. Embora uma idéia da potencialidade de sua variabilidade genética, possa ser fornecida pelos coeficientes de variação genética e índices de variação b, segundo PATERNIANI (1967); ELNIGOLY et alii (1981) e VENCOVSKY (1987).

Os coeficientes de variação genética e os índices de variação b, encontram-se nas tabelas 12 e 13, tanto para o comprimento de grãos como para a largura de grãos. Estes valores mostram que ainda exis te variabilidade genética disponível para o melhoramento destas duas caracterịsticas, principalmente para o comprimento de grãos em relação à largura de grãos, já que este caráter sofreu uma grande queda na população dentado a1to óleo.

Os coeficientes de herdabilidade no sentido restrito ao nível de médias $\left(\hat{\mathrm{h}}_{\mathrm{m}}^{2}\right)$, foram superiores aos $30 \%$ para os dois caracteres, exceto à largura de grãos na população dentado alto óleo, ante a redução da variância aditiva, Os valores obtidos para o comprimento de grãos, estiveram acima da média de sete estimativas fornecidas por HALLAUER E MIRANDA FILHO (1987) de 29,20\%. Não obstante o melhoramento destes caracteres dos grãos, visando aumentar a produção, não deveria ser feito já que estão pouco relacionados como constatou WEIGEL (1978) e se ter mais relação com outros componentes do rendimento.

Para cada uma das populações, as estimativas dos progressos genéticos esperados, com a seleção entre progênies de meios irmãos, 
(Tabelas 14 e 15), foram superiores para o comprimento de grãos em respei to aos obtidos para a largura de grãos, a exceção da população dentado original, que apresentou menor variabilidade genética.

4.2.7. Estimativas para os caracteres: peso de 100 grãos e peso de grãos

Comparando-se os valores das estimativas das variâncias ge néticas aditivas das populações de alto óleo em relação as populações or ginais (Tabelas 8, 9, 10 e 11), pode verificar-se que houve redução e aumentos respectivamente nas populações dentado e flint, como conseqüências da fixação de genes favoráveis e liberação de variabilidade genética por re combinação para o caräter peso de 100 grãos. As estimativas obtidas (gramas $)^{2}$ foram inferiores às obtidas por EL-ROUBY et alii (1973); de magnitudes semelhantes aquelas relatadas por EL-ROUBY \& PENNY (1967); TOSELLO \& GERALDI (1980b); MILLER (1981) e ZIMABCK (1985), enquanto acima dos resultados encontrados por EL-ROUBY et alii (1979ab) e SHEHATA et alii (1987).

No que concerne ao peso de grãos, as estimativas das variâncias genéticas aditivas (gramas/espiga) ${ }^{2}$, estes valores estão con tịdos nas tabelas 8, 9, 10 e 11 . Pode constatar-se que a população dentado original registrou a menor estimativa entre as quatro populações. SOARES (1987), manifestou que este caráter deve ser avaliado a partir de amostras de tamanho superior a $\left(K^{\prime} \leq 5\right)$, compreendendo preferivelmente to das as plantas de cada parcela experimental, em razão à relevante influência que exerce o ambiente sobre sua manifestação fenotípica que leva a imprecisão das estimativas de suas variâncias genêticas. Não obstante, seus valores foram coerentes com os relatados por EL-ROUBY \& PENNY (1967) 
e SOARES (1987).

Verificou-se que os valores das estimativas das variâncias genéticas aditivas para os caracteres peso de 100 grãos e peso de grãos, foram de maior magnitude nas duas populações flint. Embora as duas populações sejam contrastantes no tipo de grãos, possuem uma importante fonte de variabilidade genética para o melhoramento intrapopulacional.

Os coeficientes de variação genética e os índices de variação b, tanto para o peso de 1.00 grãos como para o peso de grãos, acham-se nas tabelas 12 e 13, respectivamente para as quatro populações. Os valores do índice $b$, o qual permite comparar melhor o potencial de variabilidade disponível para melhoramento independente das médias inerentes à população, obtidos para o peso de 100 grãos, estiveram baixos em comparação aos da literatura (TOSELLO \& GERALDI, 1980b; ZIMBACK, 1988), enquanto que para o peso de grãos, estes valores foram bastante coerentes com os relatados por SOARES (1987), a exceção da população dentado original, onde as análises de variância acusaram ausência de significância, o que indica falta de variabilidade, possivelmente pelo tamanho da amostra $\left(K^{\prime} \leq 5\right)$, posto que o rendimento apresentou significância ao nível de $1 \%$.

Quanto as estimativas dos coeficientes de herdabilidade no sentido restrito ao nível de plantas $\left(\hat{h}_{\hat{i}}^{2}\right)$ e ao nível de médias $\left(\hat{h}_{\mathbb{m}}^{2}\right)$, detectou-se que a população flint alto óleo, registrou valores superiores à população dentado alto óleo, para as duas características (Tabelas 12 e 13), sendo portanto a de maior perspectiva para combinar maior 
porcentagem de óleo e aumentos no rendimento, sempre e quando sejam utilizados esquemas de seleção que permitam aumentar o teor de óleo até certos niveis, sem causar detrimentos na produção.

Utilizando-se a seleção entre e dentro de progênies de meios irmãos, os ganhos genéticos esperados para estas duas características foram maiores para o Piranão VF-1-MI-AO em relação ao Piranão VD-2-MI-AO (Tabelas 16 e 17).

4.2.8. Estimativas para os caracteres: diâmetro do sabugo e peso do sabugo

Os valores das estimativas das variâncias genéticas aditivas $(\mathrm{cm})^{2}$ para o diâmetro do sabugo, acham-se nas tabelas $8,9,10$ e 11 . Pode constatar-se que houve decréscimos nas magnitudes das populações me1horadas para teor de óleo, evidenciando que a maior redução ocorreu no Piranão VF-1-MI-AO, devido à fixação de genes como anotaram WEBEL \& LONNQUIST (1967) e VENCOVSKY (1987).

As magnitudes das estimativas das variâncias genéticas adi tivas das populações de alto óleo não diferem quanto a variabilidade genética. Estes valores são bastante coerentes com os relatados por SANTOS (1985) e SOARES (1987), enquanto que superiores à média do levantamento efetuado por HALLAUER \& MIRANDA FILHO (1982), para este caráter.

Os valores encontrados para as estimativas das variâncias genéticas aditiva, para o peso do sabugo (gramas/espiga) ${ }^{2}$, acham-se nas tabelas $8,9,10$ e 11 . Pode verificar-se que as populações dentado apresentaram pouca variação nas magnitudes de suas variâncias genéticas 
aditiva, enquanto que a população flint alto óleo, sofreu uma notável redução em relação a sua população original, o qual obedece a suas freqüências gênicas originais em posição diferente, possivelmente altos ou baixos na população dentado e intermediārios na população flịt, posição esta onde os genes contribuem com muito mais variância (FALCONER, 1980).

Os coeficientes de variação genética e os índices de variação b, que estão contidos nas tabelas 12 e 13, mostram que estas duas características tem variabilidade genética em níveis apreciáveis, que per mitem o sucesso de programas de melhoramento, principalmente para o diâmetro do sabugo, cujos valores foram em termos gerais superiores aos reportados por SANTOS (1985) e SOARES (1987). Essa variabilidade genética poderia ser explorada na obtenção de espigas com sabugos menos pesados, para evitar o desperdício de energia na produção de sabugos mais pesados, o qual constatou-se no Piranão VD-2-MI-AO e não no Piranão VF-1-MI-AO..

Com relação às magnitudes dos coeficientes de herdabilidade no sentido restrito ao nível de plantas $\left(\hat{h}_{\mathfrak{i}}^{2}\right)$ e ao nível de médias $\left(\hat{\mathrm{h}}_{\mathrm{m}}^{2}\right)$, pode verificar-se nas tabelas 12 e 13 , que estes foram mais altos para o diâmetro do sabugo em relação ao peso do sabugo, pelo que métodos simples poderiam proporcionar progressos substanciais, principalmente nas populações dentado.

Os valores dos coeficientes de herdabilidade ao nível de médias $\left(\hat{h}_{m}^{2}\right)$, as estimativas aqui obtidas foram superiores à média de seis e oito estimativas relatadas por HALIAUER \& MIRANDA FILHO (1982), e SANTOS (1985), encontrando este ü1timo pesquisador em seu levantamento o valor de $75 \%$, enquanto que SOARES (1987), constatou que os valores • de 
suas estimativas foram superiores nas populações dentado em relação às populações flint, o que também foi evidenciado nesta pesquisa para o diâmetro do sabugo.

Considerando as estimativas dos progressos genéticos esperados com a seleção entre e dentro de progênies de meios irmãos, os maio res progressos foram obtidos para a população dentado alto óleo, em relação à população flint, para as duas características consideradas anterior mente (Tabelas 16 e 17).

4.2.9. Estimativas para os caracteres: densidade dos grãos e porcentagem de óleo

Nas tabelas $8,9,10 \cdot$ e 11 , estão os resultados das estimativas das variâncias genéticas aditivas para o caráter densidade dos grãos, (gramas $\left./ \mathrm{cm}^{3}\right)^{2}$, verificando-se que houve resposta divergente nes te parâmetro nas populações de alto óleo como resposta à seleção, com acréscịmos na população dentado alto óleo e decréscimos na população flint. Os valores obtidos nas populações dentado, foram bastante prōximos aos fornecidos por TOSELLO \& GERALDI (1980b); ZIMBACK (1985) e WESSEL-BEAVER et alii (1985), enquanto para a população flint, estes valores estiveram bem baixos em relação aos relatados pela literatura em populações dentado.

As estimativas das variâncias genéticas aditivas, para o carāter porcentagem de óleo $(\%)^{2}$, acham-se nas tabelas $8,9,10$ e 11 . Pode-se verificar que as populações dentado não apresentaram alterações significativas nas magnitudes de suas variâncias genéticas aditivas, 
entretanto a população flint a.1to óleo verificou uma queda ostensíva em seus valores. 0 comportamento das estimativas das variâncias genéticas aditivas das populações dentado, foi similar ao registrado por MILLER et alii (1981), manifestando que a pouca variação nas variâncias aditivas possivelmente obedece ao fato de que sua frequência original de genes está em algum extremo $(0,2$ ou 0,8$)$ onde as mudanças na variância genética aditiva são poucas para características controladas por muitos loci, enquanto que a redução pronunciada na variância aditiva da população alto óleo, possa ser explicada pela fixação de genes como resultado de seleção inicial, afetando a variabilidade genética como anotaram WEBEL \& LONNQUIST (1967) e VENCOVSKY (1987).

Comparando estes valores com os obtidos por outros pesquisadores, verificou-se que estes foram inferiores aos relatados por · ELROUBY \& PENNY (1967); MORENO-GONZALES et alii (1975); TOSELLO \& GERALDI (1980b); BIANCO (1984); ZIMBACK (1985) e ZANOTTO (1986) e superiores aos fornecidos por MILLER et alii (1981). As estimativas obtidas nas populações em estudo, foram de maior magnitude para as populações dentado em relação às populações flint, fato este que foi evidenciado inicialmente por BIANCO (1984). Não obstante, as duas populações de alto óleo tem suficiente variabilidade genética para continuar progredindo neste caráter, ta1 como foi demonstrado por ALEXANDER (1988), após 87 gerações de seleção para alto óleo na variedade Burr's White, o que nós dá idéia do 1imite até onde se poderā chegar com seleção para teor de óleo.

Os coeficientes de variação genética e seus índices de va riação b, para estas duas características acham-se nas tabelas 12 e 13. Pode verificar-se a existência de pouca variabilidade genética no carāter 
densidade dos grãos, fato que também foi constatado por TOSELLO \& GERALDI (1980b); ZIMBACK (1985) e WESSEL-BEAVER et alii (1985), enquanto que para a porcentagem de óleo os indices de variação b foram superiores aos reportados por ZIMBACK (1985) e ZANOTTO (1986) e abaixo dos achados por BIANCO (1984). E de se notar, que o índice de variação b, não foi modificado nas populações flint, como aconteceu nas populações dentado, apesar da população flint alto ôleo, haver registrado redução na quantificação da estimativa da variância genētica aditiva, onde a interação genótipo $\mathrm{x}$ ambiente pode ter influenciado fortemente para a estimação real deste parâmetro.

Os coeficientes de herdabilidade no sentido restrito ao nỉvel de plantas $\left(\hat{\mathrm{h}}_{\hat{i}}^{2}\right)$ e ao nível de médias $\left(\hat{\mathrm{h}}_{\mathrm{m}}^{2}\right)$, para a densidade dos grãos (Tabelas 12 e 13), mostram que são baixos e inferiores aos apresentados por TOSELLO \& GERALDI (1980b) e ZIMBACK (1985). Portanto, o melhoramento da densidade dos grãos visando aumentar a porcentagem de óleo, não deve ser considerado como critério de seleção para a obtenção de germoplasmas com maior conteúdo de óleo, uma vez que existem técnicas mais sofisticadas como o NMR que permitem a identificação rápida de sementes com maior porcentagem de óleo.

Quanto as estimativas dos coeficientes de herdabilidade no sentido restrito ao nível de plantas $\left(\hat{h}_{i}^{2}\right)$ e ao nível de médias $\left(\hat{h}_{m}^{2}\right)$, obti dos para a porcentagem de óleo (Tabelas 12 e 13), estes foram mais altos nas populações dentado em relação às populações flint e estes valores superiores aos registrados por ZIMBACK (1985) e ZANOTTO (1986), enquanto que ao nivel de médias inferiores aos manifestados por TOSELLO \& GERALDI (1980b), BIANCO (1984) e ao valor médio de quatro estimativas de HALLAUER 
\& MIRANDA FILHO (1982) para este carāter.

Como o interesse do melhorista não é só aumentar o conteūdo de óleo, a utilização de métodos com testes de progênies pode levar à obtenção de ganhos paralelos tanto para o rendimento como a porcentagem de óleo, respeitando os limites que originam detrimentos na produção.

Os progressos genéti.cos esperados com a seleção entre e dentro de progênies de meios irmãos acham-se nas tabelas 16 e 17 . Estes foram de pouca monta na densidade dos grãos, enquanto que bastante significativos para a porcentagem de óleo, principalmente para a população den tado alto óleo em respeito à população flint alto óleo, fato este que foi evidenciado por BIANCO (1984).

\subsection{Estimativas das Correlações Genéticas e Fenotípicas}

4.3.1. Correlações entre a porcentagem de óleo e os caracteres altura da planta, altura da espiga, comprimento de grãos, largura de grãos e rendimento

Nas tabelas $18,19,20$ e 21 estão apresentadas as estimativas da covariância entre progênies ( $\left.\hat{C o ̂ v}_{e}\right)$, covariância do erro ambiental entre parcelas ( $\operatorname{Côv}_{\mathrm{p}}$ ), covariância fenotỉpica entre médias de progênies $\left(\operatorname{Côv}_{\bar{F}}\right)$ e covariância genética aditiva entre plantas ( $\left.\operatorname{Côv}_{A}\right)$. As estimativas dos coeficientes de correlação genética aditiva $\left(\hat{x}_{A}\right)$, e os coeficientes de correlação fenotípica ao nível de parcelas $\left(\hat{\mathrm{r}}_{\overline{\mathrm{F}}}\right)$, encontramse nas tabelas 22 e 23 . 
As estimativas dos coeficientes de correlação genētica aditiva entre a porcentagem de óleo e os caracteres altura da planta e altura da espiga corresponderam a 0,154 e 0,$175 ;-0,014$ e $-0,023 ; 0,238$ e $-0,121$ e 0,030 e -0,032, respectivamente para o Piranão VD-2-MI-0, Piranão VD-2-MI-AO, Piranão VF-1-MI-0 e Piranão VF-1-MI-AO (Tabelas 22 e 23). Nota-se que as populações de alto teor de óleo, registraram redução dos valores e estes próximos a zero, em relação às populações originais, possivelmente pela quebra de blocos gênicos na recombinação das progênies previamente selecionadas. EL-ROUBY \& PENNY (1967) quando correlacionaram a porcentagem de óleo com a altura da planta e altura da espiga, obtiveram coeficientes de $-0,160$ e 0,052 e BIANCO (1984), valores de -0,145 e -0,296 no Piranão VD e -0,387 e -0,156 no Piranão VF. Os resultados obtidos para as populações de alto óleo, são coerentes com os fornecidos pela literatura em populações melhoradas para este carāter, que é bastante benéfico já que permite que sejam obtidos germoplasmas de menor altura tanto da planta como da espiga.

Os coeficientes de correlação genética aditiva entre a porcentagem de óleo e os caracteres comprimento de grãos e largura de grãos, foram de -0,299 e -0,578 no Piranão VD-2-MI-0, 0,094 e -0,799 no Piranão VD-2-MI-AO, -0,495 e 0,595 no Piranão VF-1-MI-0 e -0,802 e 0,239 para o Piranão VF-1-MI-AO (Tabelas 22 e 23). Observa-se que as correlações de maneira geral afetam muito mais estes caracteres dos grãos nas populações flint que dentado, situação que constata o porque as populações flint apresentam grãos muito mais pequenos que as dentado. Não foi possível comparar estes resultados com os obtidos por outros pesquisadores, por não encontrar literatura associada a estas características. Parece que 
a seleção para maior porcentagem de óleo nas populações dentado, pode levar a modificações divergentes no tamanho do grão em relação às populações flint, possivelmente pela diferença nos mecanismos de sínteses de óleo. Uma alternativa a esta situação para não sacrificar o tamanho da semente, è aumentar o número de progênies a ser avaliadas e selecionar aquelas que apresentem associação menos estreita.

As estimativas das correlações genética aditiva entre a porcentagem de óleo e o rendimento foram de $-0,018 ; 0,025 ; 0,063$ e -0,385, respectivamente para as quatro populações e estão contidas nas tabelas 22 e 23. Eștes valores são de baixa magnitude exceto para o Piranão VF-1-MI-AO, por conseguinte é de se esperar aumentos concomitantes para estas duas características no dentado alto óleo e decréscimos para o rendimento no flint alto óleo, se não são tomadas as precauções necessárias para evitar queda neste caráter. Resultados obtidos por outros pesquisadores como EL-ROUBY \& PENNY (1967) foram de -0,247; DUDLEY et alii (1977) -0,490; TOSELLO \& GERALDI (1980b) -0,500; RAMAN et alii

0,400 e 0,250; BIANCO (1984) 0,070 e -0,224; ZIMBACK (1985) 0,198 e 0,152; ZANOTTO (1986) -0,370 e 0,120 e MISEVIC \& ALEXANDER (1989) -0,960; -0,300 e $-0,150$. Verifica-se que a maioria destes trabalhos mostram a existência de uma associação negativa entre os dois caracteres e de maior magnitude aos obtidos no presente trabalho. Paterniani, segundo BIANCO (1984) observou menor produção de espigas e alto teor de óleo nas populações flint em relação às populações dentado, fato este que concorda com os resultados desta pesquisa. Não obstante, houve na população Piranão VF-1-MI-AO, aumentos na porcentagem de óleo e rendimento pela existência de correlação positiva entre estas duas características na população Piranão VF-1-MI-0. 
4.3.2. Correlações entre a porcentagem de óleo e os caracteres comprimento da espiga, diâmetro da espiga, número de fileiras e número de grãos por fileira

As estimativas das covariâncias genéticas ambientais e fenotípicas obtidas ao nỉvel de plantas entre a porcentagem de óleo e os caracterés comprimento da espiga, diâmetro da espiga, número de fileiras e número de grãos por fileira, acham-se nas tabelas 18, 19, 20 e 21 . Os coeficientes de correlação genética aditiva e fenotípica nas tabelas 24 e 25.

As correlações genética aditiva registradas entre a porcentagem de óleo e os caracteres comprimento da espiga e diâmetro da espiga, foram de 0,600 e -0,492 para o Piranão VD-2-MI-0, 0,317 e 0,469 para o Piranão VD-2-MI-A0, -0,238 e -0,344 para o Piranão VF-1-MI-0 e -0,001 e -0,550 para o Piranão VF-1-MI-AO (Tabelas 24 e 25). Observa-se que todas as correlações nas populações flint foram negativas e a exceção da associação da porcentagem de óleo com o diâmetro da espiga no Piranão VD-2-MI-0, estas foram positivas nas populações dentado. Os coeficientes obtidos para o comprimento da espiga nas populações flint, apresentaram similar tendência aos obtidos por MISEVIC \& ALEXANDER (1989) de -0,77; $-0,01$ e -0,78, WOODWORTH et alii (1952), encontraram redução no compri mento da espiga das linhagens Illinois High 0il em relação às linhagens Illinois Low 0il. A discrepância obtida com as populações dentado possivelmente sejam originadas pelas diferenças nas magnitudes do conteúdo de óleo. RAMAN et alii (1983), reportaram estimativas de 0,216 e 0,305 entre estes caracteres, com populações de menor porcentagem de óleo. 
As estimativas dos coeficientes de correlação genética aditiva entre a porcentagem de óleo e o diâmetro da espiga, foram negativas, exceto para o Piranão VD-2-MI-AO. RAMAN et alii (1983) forneceram estimativas de baixa magnitude 0,033 e $-0,106$ as quais indicam independência biológica entre eles. Estes valores são inferiores quando comparados com os deste trabalho.

Os resultados obtidos para as estimativas dos coeficientes de correlação genética aditiva entre a porcentagem de óleo e o número de fileiras e número de grãos por fileira foram de 0,198 e 0,479 para o Piranão VD-2-MI-0, 0,695 e -0,191 para o Piranão VD-2-MI-AO, -0,707 e 0,140 para o Piranão VF-1-MI-0 e -0,180 e 0,307 para o Piranão VF-1-MI-AO (Tabelas 24 e 25). MISEVIC \& ALEXANDER (1989) reportaram correlações de 0,37; 0,13 e 0,28 entre a porcentagem de óleo e o número de fileiras. RAMAN et alii (1989) encontraram associações positivas e próximas a zero entre a porcentagem de óleo e o número de grãos por fileira 0,201 e 0,130. Constata-se portanto que os resultados desta pesquisa nas populações de alto óleo são bastante próximos aos da literatura, principalmente para as populações flint, que tem maior conteúdo de óleo, evidenciando a possibilidade de aumentar o número de grãos por fileira e a porcentagem de óleo paralelamente, até onde os limites fisiológicos o permitam. 


\begin{abstract}
4.3.3. Correlações entre a porcentagem de óleo e os caracteres peso de grãos, peso de 100 grãos, densidade dos grãos, diâa metro e peso do sabugo
\end{abstract}

As estimativas das correlações genéticas aditivas entre a porcentagem de óleo e os caracteres peso de grãos e peso de 100 grãos foram de $-0,471$ e $-0,389$ para o Piranão VD-2-MI-0, 0,678 e 0,041 para o Piranão VD-2-MI-AO, -0,109 e -0,752 para o Piranão VF-1-MI-0 e -0,312 e -0,768 para o Piranão VF-1-MI-AO (Tableas 24 e 25). Comparando estes resultados com os obtidos por outros pesquisadores nota-se a existência de discrepância entre estes pela variação no sinal e magnitudes dos mesmos. Para a associação entre a porcentagem de óleo e pelo de 100 grãos. ALEXANDER \& SEIF (1963) encontraram valores de $-0,02$ e 0,08; EL-ROUBY \& PENNY (1967) de -0,054; DUDLEY et alii (1977) de -0,85; TOSELLO \& GERALDI (1980a) de 0,101; RAMAN et alii (1989) de 0,229 e 0,086 e MISEVIC \& ALEXANDER (1989) de 0,88; -0,41 e -0,78. A falta de uma boa concordância entre estes resultados, pode ser por problemas de amostragem e não representar o potencial genético como comentaram TOSELLO \& GERALDI (1980a), além do grau de melhoramento de cada população.

As estimativas dos coeficientes de correlação genética aditiva entre a porcentagem de óleo e densidade dos grãos, foram de $-0,127$, 0,$417 ;-0,254$ e $-0,273$, respectivamente para as quatro populações e estão contidos nas tabelas 24 e 25 . 
Nota-se que estes coeficientes são negativos em sua maioria e os decréscimos observados na densidade dos grãos, provavelmente ocorrem por modificações no endosperma que afetam a relação peso de 100 grãos/volume de 100 grãos. MIRANDA et alii (1976) encontraram correlações fenotípicas de 0,089 o qual è semelhante aos valores das Tabelas 24 e 25.

Os valores das estimativas das correlações genéticas aditivas entre a porcentagem de óleo e os caracteres diâmetro do sabugo e peso do sabugo foram de $-0,258$ e 0,053 para o Piranão VD-2-MI-0, 0,361 e 0,438 para o Piranão VD-2-MI-AO, -0,011 e 0,013 para o Piranão VF-1-MI-0 e -0,081 e -0,006 para o Piranão VF-1-MI-AO (Tabelas 24 e 25). Em razão à falta de literatura apresentando correlações entre estas características foi impossîvel comparar os resultados obtidos. Constata-se a exístência de divergência entre as populações dentado e flint para estas associações, já que as populações flint obtiveram valores próximos a zero denotando independência biológica entre eles. Portanto, a seleção para alta porcentagem de óleo não causa alterações significativas para o diâmetro do sabugo e peso do sabugo. As populações dentado podem sofrer modificações para estas duas características e fazer sentir indiretamente sua influência no peso da espiga.

0 conhecimento dos coeficientes de correlação entre a porcentagem de óleo e caracteres da planta, componentes da espiga e o rendimento dos milhos dentado e flint, indicam que estas são divergentes em sua resposta à seleção para incrementar o conteúdo de óleo na semente. 
Portanto, devem-se tomar precauções para evitar o sacrïfício de outras caracterỉsticas desejāveis, principalmente nos milhos flint, jä que seus teores estão próximos ao nível de $7 \%$, mediante a avaliação de maior nú mero de progênies com o propósito de identificar aquelas que apresentem associações mínimas entre elas e assim progredir na porcentagem de óleo e produção de grãos, sem causar detrimentos em outros aspectos da planta.

\subsection{Respostas Correlacionadas Esperadas com Seleção}

As estimativas das respostas correlacionadas entre a porcentagem de óleo e os caracteres estudados acham-se nas tabelas 26 e 27.

As respostas correlacionadas entre os caracteres altura da planta, altura da espiga e porcentagem de óleo foram de 1,12 e 1,73\%; $-0,0.9$ e $-0,20 \% ; 0,99$ e $-2,49 \%$ e 0,25 e $-0,38 \%$, respectivamente para o Piranão VD-2-MI-O, Piranão VD-2-MI-AO, Piranão VF-1-MI-0 e Piranão VF-1-MI-A0. Estes valores são de baixa magnitude quando comparados com os ganhos genéticos esperados nas tabelas 14 e 15, estimados para seleção no prōprio caráter. Esta situação obedece aos valores dos coeficientes de correlação genética aditiva que estão próximos a zero, indicando que para as populações em estudo, a seleção para aumentar o conteúdo de óleo tem pouco efeito nas populações melhoradas para estes caracteres. 
Estimativas das respostas correlacionadas entre o comprimento de grãos, largura de grãos e a porcentagem de óleo, foram de $-1,40$ e $-2,75 \%, \quad 0,48$ e $-1,80 \%,-3,26$ e $1,61 \%$ e $-3,69$ e $-0,77 \%$, respectivamente para o Piranão VD-2-MI-0, Piranão VD-2-MI-AO, Piranão VF-1-MI-O e Piranão VF-1-MI-AO (Tabelas 26 e 27). Constata-se que as populações podem ser modificadas para estes caracteres principalmente as populações flint e que futuros ganhos causariam decréscimos no comprimento de grãos.

As respostas correlacionadas entre o rendimento e a porcentagem de óleo, foram de $-0,18 ; 0,19 ; 0,60$ e $-2,83$, respectivamente para as populações dentado e flint (Tabelas 26 e 27). BIANCO (1984) reportaram valores de 3,73 e $-7,64 \%$ para Piranão VD e Piranão VF e ZIMBACK (1985) 1,01 e 0,83\% para as subpopulações A e B da variedade Dentado Braquítíco Opaco. Isto mostra que as populações dentado alto óleo pode aumentar paralelamente o rendimento e a porcentagem de óleo, enquanto que a população flint alto óleo pode reduzir o rendimento significativamente como consequência dos acréscimos na porcentagem de óleo.

Os valores das respostas correlacionadas entre o diâmetro da espiga, comprimento da espiga e a porcentagem de óleo, foram de $-2,10$ e $3,15 \% ; 1,56$ e $5,92 \%$; $-1,62$ e $-1,59 \%$ e $-2,25$ e $-5,72 \%$, respectivamente para o Piranão VD-2-MI-0, Piranão VD-2-MI-AO, Piranão VF-1-MI-O e Piranão VF-1-MI-AO (Tabelas 26 e 27). Nota-se a existência de discordância no comportamento das populações dentado e flint como reflexo da seleção para conteúdo de óleo. Não obstante, as alterações resultantes nas médias fenotípicas foram de pouca monta e talvez ciclos posteriores de seleção apresentem modificações mais significativas para estes caracteres. 
As respostas correlacionadas entre o número de fileiras e nümero de grãos por fileira foram de 1,77 e 4,23\% para o Piranão VD-2-MI-0, 3,24 e -1,11\% para o Piranão VD-2-MI-AO, $-4,25$ e $1,51 \%$ para o Piranão VF-1-MI-O e -0,87 e 2,27 para o Piranão VF-1-MI-AO (Tabelas 26 e 27). Verifica-se que a seleção praticada no caráter porcentagem de óleo, levou a respostas contrastantes no número de fileiras e número de grãos por fileira, em relação às populações originais.

Os valores obtidos das respostas correlacionadas entre a densidade dos grãos e a porcentagem de óleo, foram de $-0,20 ; 0,83 ;-0,22$ e $-0,20 \%$, respectivamente para as quatro populações (Tabelas 26 e 27). 2IMBACK (1985) reportou valores de $-2,01$ e $-1,15 \%$ para as subpopulações A e B da variedade Dentado Braquítico Opaco. Apesar da baixa magnitude encontrada nos valores desta pesquịsa eles apresentaram a mesma tendência encontrada na literatura a exceção de Piranão VD-2-MI-AO sem causar modificações significativas como resultado indireto da seleção para a porcentagem de óleo,

As respostas correlacionadas entre o peso de grãos, peso de 100 grãos e porcentagem de óleo foram de $-0,81$ e $-4,78 \%$ para o Piranão VD-2-MI-0, 0,83 e 0,33\% para o Pịanão VD-2-MI-A0, -1,70 e $-3,33 \%$ para o Piranão VF-1-MI-O e -3,27 e -6,08\% para o Piranão VF-1-MI-AO (Tabelas 26 e 27). Sendo inferiores em termos gerais aos valores obtidos por ZIMBACK (1985) de $-7,17$ e -5,51\% entre o peso de 100 grãos e a porcentagemde óleo, para as subpopulações A e B da variedade Dentado Braquítico Opaco. Verifica-se que as seleções praticadas para a porcentagem de óleo conduz a respostas correlacionadas de maiores magnitudes para as populações flint em relação às populações dentado implicando em problemas para a seleção 
por afetar negativamente o peso de 100 grãos e portanto a produção de grão.

As respostas correlacionadas entre o diâmetro do sabugo, peso do sabugo e a porcentagem de óleo foram de baixa magnitude para as populações flint, o que indica que a seleção para a porcentagem de óleo na semente não causa alterações significativas para estes caracteres. Para a população Piranão VD-2-MI-AO, as magnitudes foram de alto valor e positivas, o que evidencia que muita energia é desviada ao sabugo, afetando o peso dos grãos e consequentemente o rendimento. 
5. CONCLUSÕES

Os resultados obtidos nas condições do presente trabalho permitiram apontar as seguintes conclusões:

a) 0 esquema de seleção recorrente foi eficiente no me1horamento da porcentagem de óleo na semente de mi1ho, com acréscimos de 21,21 e $13,42 \%$, respectivamente para o Piranão VD-2-MI-AO e Piranão VF-1-MI-AO.

b) A seleção para alto óleo na semente de milho não conduziu a alterações significativas nas mëdias fenotípicas da densidade dos grãos, número de fileiras e diâmetro do sabugo das populações melhoradas em relação às populações originais sugerindo que não deveriam ser consideradas em futuras avaliações. 
c) A exceção do carāter densidade dos grãos, as estimativas de variância genética aditiva para os caracteres, são de boa magnitude para a obtenção de progressos em programas de melhoramento, principalmente para a altura da planta e altura da espiga.

d) Verificou-se a presença de suficiente variabilidade genética para a porcentagem de óleo nas duas populações de alto óleo, principalmente no dentado, uma vez que valores razoáveis para os coeficientes de herdabilidade, indice de variação e progressos genéticos foram encontrados, podendo-se conseguir ganhos concomitantes com o rendimento, utilizando métodos de seleção com testes de progênies.

e) A seleção para aumentar a porcentagem de óleo, alterou o sentido das correlações genéticas aditivas entre a porcentagem de óleo e o rendimento para as populações de alto óleo em relação às populações originais, possivelmente pela quebra de blocos gênicos.

f) Os baixos valores dos coeficientes de correlação genética aditiva entre a porcentagem de óleo e altura da planta e altura da espiga nas populações de alto óleo, indicam que estes caracteres podem ser melhorados independentemente. 
g) Houve uma redução nos ganhos genéticos para a porcentagem de óleo nas populações Piranão VD-2-MI-AO e Piranão VF-1-MI-A0, em relação a suas populações originais. Assim mesmo, o ganho para o dentado alto óleo foi superior ao obtido pelo flint alto óleo, como conseqüência da queda na variância genética aditiva e variabilidade genética livre. 
REFERÊNCIAS BIBLIOGRĀFICAS

ALEXANDER, D.E. \& SEIF, R.D. Relation of kernel oil content to some agronomic traits in maize. Crop Science, Madison, 3(4):354-55, 1963.

ALEXANDER, D.E. \& LAMBERT, R.J. Relationship of kernel oil content to yield in maize. Crop Science, Madison, 8(3):273-4, 1968

ALEXANDER, D.E. Breeding special nutritional and industrial types. In: SPRAGUE, G.F. \& DUDLEY, J.W. ed, Corn and Corm Improvement. 2 a edição. Madison, American Society of Agronomy, 1988, p.869-80.

BASSOI, M.C. Avaliação de progênies de meios irmãos de milho (Zea mays L.) em função do tipo de endosperma. Piracicaba, 1987. 127p. (Mestrado - Escola Superior de Agricultura "Luiz de Queiroz"/USP).

BATISTA, L.A. Seleção para tamanho do embrião relacionada com o teor de óleo do grão de milho (Zea mays L.). Piracicaba, 1980. 72p. (Mestrado - Escola Superior de Agricultura "Luiz de Queiroz"USP). 
BATISTA, L.A. \& TOSELLO, G.A. Alterações nos caracteres de peso, volume e densidade dos grãos de milho (Zea mays L.) provocadas pela seleção segundo o tamanho do embrião. Anais da Escola Superior de Agricultura "Luiz de Queiroz". Piracicaba, 44(1):533-47, 1987.

BAUMAN, L.F.; CONWAY, T.D.; WATSON, S.A. Heritability of variations in oil content of individual corn kernel. Science, New York, 139(3554): 498-9, 1963

BAUMAN, L.F.; CONWAY, T.D.; WATSON, S.A. Inheritance of variations in oil content of individual corn (Zea mays L.) kernel. Crop Science, Madison, 5(2):137-8, 1965.

BIANCO, S. Avaliação do potencial genético de populações de milho (Zea mays L.) braquítico para teor de óleo na semente. Piracicaba, 1984. 98p. (Mestrado - Escola Superior de Agricultura "Luiz de Queiroz"/ USP).

BIANCO, S.; TOSELLO, G.A.; SQUZA JUNIOR, C.L. Correlações genéticas e fenotípicas em duas populações de milho (Zea mays L.) braquítico e suas implịcações no melhoramento do teor de óleo no grão. Anais da Escola Superior de Agricultura "Luiz de Queiroz", Piracicaba, 44(1): 801-9, 1987

BIGOTO, C.A. Estudo da população ESALQ-PBI de milho (Zea mays L.) em cin co ciclos de seleção recorrente. Piracicaba, 1988. 124p. (Mestrado - Escola Superior de Agricultura "Luiz de Queiroz"/USP). 
CANTON, T. Avaliação de oito ciclos de seleção recorrente na população de milho (Zea mays L.) Suwan DMR. Piracicaba, 1988. 112p. (Mestrado - Escola Superior de Agricultura "Luiz de Queiroz"/USP).

CAPITANIO, R.; GENTINETTA, E.; MOTTO, M. Grain weight and its components in maize inbred lines. Maydica, Bergano, 28(4):365-79, 1983.

COLNAGO, L.A. Espectrômetro de ressonância magnética nuclear. Informativo UAPDIA, São Carlos, 6:2, jul/dez. 1989.

CROSBIE, T.M. e MOCK, J.J. Changes in physiological traits associated with grain yield improvement in three maize breeding programs. Crop Science, Madison, 21(2):255-58, 1981.

CURTIS, J.J.; BRUNSON, A.M.; HUBBARD, J.E.; EARLE, F.R. Effect of the - pollen parent on oil content of the corn kernel. Agronomy Joumal, Madison, $48(12): 551-5,1956$.

CURTIS, P.E.; LENG, E.R.; HAGEMAN, R.H. Developmental changes in oil and fatty acid content of maize strains varying in oil content. Crop Science, Madison, 8(6):689-93, 1968.

DE LA ROCHE, I.A.; ALEXANDER, D.E.; WEBER, E.J. Inheritance of oleic and linoleic acids Zea mays L.. Crop Science, Madison, 11(6):856-9, 1971.

DUDLEY, J.W.; LAMBERT, R.J.; ALEXANDER, D.E. Seventy generations of selection for oil and protein in maize. In: DUDLEY, J.W. ed. Seventy generations of selection for oil and protein in maize. Madison. Crop Science Society of America, 1974. p.181-211. 
DUDLEY, J.W. Seventy-six generations of selection for oil and protein percentage in maize. In: JNTERNATIONAL CONFERENCE ON QUANTITATIVE GENETICS, Ames, 1976. Proceedings, Ames, Iowa State University Press, 1977. p.459-73.

DUDLEY, J.W.; LAMBERT, R.J.; DE LA ROCHE, J.A. Genetic analysis of crosses among corn strains divergently selected for percent oil and protein. Crop Science, Madison, 17(1):111-7, 1977.

EL-NIGOLY, 0.0.; ISMAIL, A.A.; ABUL-FADL, M.A. Genetic variability and correlation studies in maize (Zea mays L.) Egyptian Joumal of Genetic and Cytology, Giza, 10(1):69--76, 1981

EL-ROUBY, M.M. \& PENNY, L.H. Variation and covariation in a high oil population of corn (Zea mays L.) and their implications in selection. Crop Science, Madison, 7(3):216-9, 1967.

EL-ROUBY, M.M.; KORAIEM, Y.S.; NAWAR, A.A. Estimation of genetic variance and its components in maize under stress and non-stress environments. Egyptian Journal of Genetics and Cytology, Giza, 2(1):10-19, 1973.

EL-ROUBY, M.M.; GAD, A.M.; ABDULLAH, R.M. Comparative studies on estimation of genetic variances in maize (Zea mays $\mathrm{L}_{\text {.) }}$ from $\mathrm{S}_{1}$ lines and design. Egyptian Joumal of Genetics and Cytology, Giza, 8(1):95-106, 1979a.

EL-ROUBY, M.M.; GAD, A.M.; SHOUMAN, R.A. Component of genetic variance and their interactions with locations and years in maize from design II. Egyptian Joumal of Genetics and Cytology, Giza, 8(1):107-121, $1979 b$. 
FALCONER, D.S. Introducción a la genética quantitativa. 10. ed. México, Continental, 1980. 430p.

FERREIRA, S.N. Propriedades genéticas e potencial para o melhoramento dos compostos de milho (Zea mays L.). Piracicaba, 1986. 105p. (Mestrado - Escola Superior de Agricultura "Luiz de Queiroz"/USP).

FITCH, B. Corn oil. Journal of the American Oil Chemists Society, I11inois, $62(11): 1524-27,1985$.

GAJIC, M. \& SAVIC, R. Efficiency of recurrent selection in maize breeding for high oil content. In: MEETING OF THE MAIZE AND SORGHUM, 10., Varna, 1979. Proceedings. Apud Plant Breedings Abstracts, Cambridge, $54(9)$ : 649, sept. 1984. (Resumo).

GALAL, H.E.; ABD-ALLA, S.A.; EL-KASSABY, Y.A. Effect of sample size on precision of the estimates of genetic variance in maize II ear characters. Egyptian Journal of Genetic and Cytology, Giza, 6(2):30678,1977

GARWOOD, D.L.; WEBER, E.J.; LAMBERT,R.J.; ALEXANDER, D.E. Effects of different cytoplasms on oil fatty acids, plant height, and ear height in maize (Zea mays L.). Crop Science, Madison, 10(1):39-41, 1970.

GERALDI, I.0. Estimação de parâmetros genéticos de caracteres do pendão em milho (Zea mays L.) e perspectivas de melhoramento. Piracicaba, 1977. 103p. (Mestrado - Escola Superior de Agricultura "Luiz de Queiroz"/USP). 
GERALDI, I.0.; VENCOVSKY, R.; MIRANDA FILHO, J.B. Processo para estimação dos componentes de covariância entre caracteres avaliados com números diferentes de individuos por parcela. Relatório Cientifico do Departamento de Genética. Piracicaba, 12:84-91, 1978.

GOLDENBERG, J.B. E1 empleo de la correlaciōn en el mejoramiento genético de las plantas. Fitotecnia Latinocmericana, Bogotā, 5(2):1-8, 1968.

HALLAUER, A.R. \& MIRANDA FILHO, J.B. Quantitative genetics in maize breeding. Ames, the Iowa State University Press, 1982. 468p.

HOPKINS, C.G. Improvement in the chemical composition of the corn kernel. In: DUDLEY, J.W., ed. Seventy generations of selection for oil and protein in maize, Madison, Crop Science Society of America, 1974. p. $1-31$

HOPKINS, C.G.; SMITH, L.H.; EAST, E.M. The structure of the corn kerne1 and the composition of its different parts. In: DUDLEY, J.W., ed. Seventy generations of selection for oil and protein inmaize. Madison, Crop Science Society of America, 1974, p.33-63.

JELLUM, M.D. \& MARION, J.E. Factors affecting oil content and oil composition of corn (Zea mays L.) grain. Crop Science, Madison, $6(1): 41-2,1966$.

JELLUM, M.D. \& WIDSTROM, N.W. Inheritance of stearic acid in germ oil of the maize kerne1. The Journal of Heredity, Washington, 74(5):3834, 1983. 
JUGENHEIMER, R.W. Breeding for oil and protein content in maize. Euphytica, Wageningen, 10(2):152-6, 1961.

KEMPTHORNE, 0. An introduction to genetic statistics 3 ed. New York, John Wiley \& Sons, 1966. 545p.

LAMBERT, R.J.; ALEXANDER, D.E.; RODGERS, R.C. Effect of kernel position on oil content in corn (Zea mays L.). Crop Science, Madison, 7(2): $143-4,1967$.

LEMOS, M.A.; DE ARAUJO, M.; GOMES, E.E.; MAGNAVACA, R.; DE OLIVEIRA, A. C.; RAMALHO, A. Seleção entre e dentro de famỉlias de meios irmãos no milho dentado composto visando resistência a Spodoptera frugiperda e a Heliothis zea II ciclo. Pesquisa Agropecuäria Brasileira. Ser. Agronômica, Brasîlia, 25(1):95-101, 1990.

LENG, E.R. Results of long-term selection for chemical composition in maize and their significance in evaluating breeding systems. In: DUDLEY, S.W. ed. Seventy generations of selection for oil and protein in maize, Madison, Crop Science Society of America, 1974. p.149-73.

LIMA, M. Seleção entre e dentro de famỉlias de meios irmãos na população ESALQ/VD-2. Piracicaba, 1977. 71p. (Mestrado - Escola Superior de Agricultura "Luiz de Queiroz"/USP).

MILLER, P.A. \& BRIMHALL, B. Factors influencing the oil and protein content of corn grain. Agronomy Journal, Madison, 43(7):305-10, 1951. 
MILLER, R.L.; DUDLEY, J.W.; ALEXANDER, D.E. High intensity selection for percent oil in corn. Crop Science, Madison, 21(3):433-7, 1981.

MIRANDA, P•; RUSCHEL, R.; PATERNIANI, E. Avaliação de famílias de meios irmãos no milho (Zea mays L.) Centralmex para produção de grãos eóleo. Boletim Técnico Instituto de Pesquisa Agronômica, Recife, 76:1-37, 1976.

MISEVIC, D. \& ALEXANDER, D.E. Twenty-four cycles of phenotypic recurrent selection for percent oil in maize. I. Per-se and test-cross performance. Crop Science, Madison, 29(2):320-24, 1989.

MISOVIC, M•; RATKOVIC, S•; MIHAJLDVIC, M•; KAPOR, S.; TRIFUNOVIC, V.; DUMANOVIC, J. Variability of content and fatty acid composition of oil in maize and breeding potential abstracts. Plant Breeding Abstracts, Cambridge, 50(3):181, mar. 1980. (Resumo).

MITRA, R. \& BHATIA, C.R. Bioenergetic considerations in the improvement of oil content and quality in oil seed crops. Theoretical and Applied Genetic, Berlin, 54(1):41-7, 1979.

MORENO-GONZALEZ, J.; DUDLEY, J.W.; LAMBERT, R.J. A design III study of linkage disequilibrium for percent oil in maize. Crop Science, Madison, 15(6):840-3, 1975 .

NAWAR, A.A. Genetic variances in a synthetic variety of maize (Zea mays L.). E'gyptian Joumal of Genetics and Cytology, Giza, 15(1):1-8, 1986. 
ORTIZ, J.C.; MENDOZA, L.E.; GONZALEZ, V.A. Cambios en Las características morfológicas y fisiotecnicas de maiz por efecto de la selección in situ y rotativa basada en el rendimiento de grano. Agrociencia, Chapingo, 58:153-163, 1984.

PAMIN, K.; COMPTOU, W.A.; WALKER, C.E.; ALEXANDER, D.E. Genetic variation and selection response for oil composition in corn. Crop Science, Madison, 26(2):279-82, 1986 .

PATERniani, E. Avaliação do método de seleção entre e dentro de famílias de meios irmãos no melhoramento do milho (Zea mays L.) Piracicaba, 1968. 92p. (Cátedra - Escola Superior de Agricultura "Luiz de Queiroz"/USP).

PATERNIANI, E.; ZINSLY, J.R.; MIRANDA, J.B. Populações melhoradas de miTho obtidas pelo Instituto de genética. Relatório Cientifico do Departamento de Genética, Piracicaba, 11:108-14, 1977.

PENNING, F.W.; BRUSTING, A.H.; VAN LAAR, H.H. Products, requeriments and efficiency of biosynthesis: a quantitative approach. Journal of Theoretical Biology, London, 45:334-77, 1974.

PLEWA, M.J. \& WEBER, D.F. Monosomic analysis of fatty acid composition in embryo lipids of Zea mays L. Genetics, Austin, 81(2):277-86, 1975.

PONELEIT, C.E. \& BAUMAN, L.F. Diallel analysis of fatty acids in corn (Zea mays L.) oil. Crop Science, Madison, 10(4):338-41, 1970. 
QUEIROZ, M.A. Correlações genéticas e fenotípicas em progênies de meios irmãos de milho (Zea mays L.) e suas implicações com o melhoramento. Piracicaba, 1969. 71p. (Mestrado - Escola Superior de Agricultura "Luiz de Queiroz"/USP).

RAMAN, R.; SARKAR, K.R.; SINGH, D. Correlations and regressions among oil content, grain yield and yield components in maize. Indian Journal Agricultural Science, New Delhi, 53(5):285-88, 1983.

REDDY, V.M. e DAYNARD, T.B. Endosperm characteristic associated with rate of grain filling and kernel size in corn. Maydica, Bergano, $28(4): 339-55,1983$.

ROBERTSON, J.A. \& WINDHAM, W.R. Comparative study of methods of determining oil content of sunflower seed. Journal of the American Oil Chemists Society, Illinois, 58(11):993-4, 1981.

RUSCHEL, R. \& BAUMAN, L.F. Seleção para alto teor de óleo no 'grão numa população de mịlho opaco-2. Pesquisa Agropecuária Brasileira. Ser. Agronômica, Brasîlia, 8(8):239-44, 1973.

SANTOS, M.X. Estudo do potencial genētico de duas raças brasileiras de milho (Zea mays L.) para fins de melhoramento. Piracicaba, 1985. 186p. (Doutorado - Escola Superior de Agricultura "Luiz de Queiroz"/ USP) . 
SANTOS, M.X. e NASPOLINI-FILHO, V. Estimativas de parâmetros genēticos em três ciclos de seleção entre e dentro de famílias de meios irmãos no milho (Zea mays L.) dentado composto nordeste. Revista Brasileira de Genética, Ribeirão Preto, 9(2):307-19, 1986.

SCHADLEY, J. \& WEBER, D. Location of chromosomal regions controlling fatty acid composition of embryo oil in Zea mays L.. Canadian Joumal of Genetic and Citology, Ottawa, 28(2):260-5, 1986.

SHEHATA, A.H.; ERAKY, A.G.; SADEK, S.E.; KHALIFA, M.A.; DIAB, M. E. Improvement of grain yield and its components in two maize populations. II design I mating scheme. Egyptian Journal of Genetics and Cytology, Giza, 16(1):181-89, 1987a.

SHEHATA, A.H.; ORABY, F.T.; SADEK, S.E;; EL-IRIBY, H.A. e DIAB, M.T. Improvement of grain yield and its components in two maize populations. I $S_{1}$ progeny selection method. Egyptian Joumal of Genetics and Cytology, Giza, 16(1):171-80, $1987 \mathrm{~b}$.

SINCLAIR, T.R. e DE WIT, C.T. Photosynthate and nitrogen requeriments for seed production by various crops. Science, New York, 189(4202): $565-67,1975$.

SMITH, L.H. Ten generations of corn breeding. In: DUDLEY, J.W., ed. Seventy generations of selection for oil and protein inmaize, Madison, Crop Science Society of America, 1974. p.65-94. 
SOARES, W.dos. Características fenotípicas e genéticas das populações de - milho (Zea mays L.) braquítico Piranão-VD2B e Piranão-VF1B. Piracicaba, 1987. 185p. (Doutorado - Escola Superior de Agricultura "Luiz de Queiroz"/USP).

SOUZA JUNIOR, C.L. Variabilidade genētica em milho (Zea mays L.) e relações com a seleção recorrente intra e interpopulacional. Piracicaba, 1983. 151p. (Doutorado - Escola Superior de Agricultura "Luiz de Queiroz"/USP).

SPRAGUE, G.F. \& BRIMHALL, B. Quantitative inheritance of oil in the corn kernel. Agronomy Journal, Madison, 41(1):30-3, 1949.

SPRAGUE, G.F. \& BRIMHALL, B. Relative effectiveness of two systems of selection of oil content of the corn kernel. Agronomy Joumal, Madison, $42(2): 83-8,1950$.

SPRAGUE, G.F.; MILLER, P.A.; BRIMHALL, B. Additional studiés of the relative effectiveness of two systems of selection for oil content of the corn kerne1. Agronomy Journal, Madison, 44(6):329-31, 1952.

STEEL, R.G. \& TORRIE, J.H. Principles and procedures of statistics. New York. Mc Graw-Hi11, 1960, 481p.

TIẄARI, P.Ñ.; GAMBHIR, P.Ñ.; RẢJAÑ, T.S. Rapid and non destructive determination of seed oil by pulsed nuclear magnetic ressonance technique. Journal of the American Oil Chemists Society, Illinois, $5 I(3): 104-9,1974$. 
TOSELLO, G.A. Introdução do gene opaco-2 no composto dentado. Relatório Cientifico do Departamento de Genética. Piracicaba, 9:170-2, 1975.

TOSELLO, G.A. \& GERALDI, I.0. Correlações genéticas e fenotípicas envo1vendo caracteres da planta e de qualidade do grão na população ESALQVD opaco de milho. Relatório Cientifico do Departamento de Genética Piracicaba, 14:190-3, 1980a.

TOSELLO, G.A. \& GERALDI, I.0. Estimativas de parâmetros genéticos e fenotípicos para caracteres da planta e da qualidade de grão na população de milho ESALQ-VD opaco. Relatório Cientifico do Departamento de Genêtica, Piracicaba, 14:183-9, 1980b.

TRIFUNOVIC, V.; RATKOVIC, S.; MISOVIC, M.; KAPOR, S.; DUMANOVIC, J . Variability in content and fatty acid composition of maize oil. Maydica, Bergano, 20(4):175-83, 1975.

TYAGI, A.P.; POKHARIYAL, G.P.; ODONGO, O.M. Correlation and path coefficient analysis for yield components and maturity traits in maize (Zea mays L.). Maydica, Bergano, 33(2):109-19, 1988.

VARGAS, J.E.; MOLINA, J.D.; CERVANTES, T. Seleccion masal y parämetros genéticos en la variedad de maiz ZAC 58. Agrociencia, Chapingo, 48: 93-105, 1982. 
VELLO, N.A. \& VENCOVSKY, R. Variâncias associadas as estimativas de variâncias genéticas e coeficientes de herdabilidade. Relatório Cientifico do Departamento de Genética, Piracicaba, 8:238-48, 1974.

VENCOVSKY, R. Genética quantitativa. In: KERR, W.E. Org. Melhoramento e Genética. São Paulo, Melhoramentos, 1969. p.17-38.

VENCOVSKY, R. Herança quantitativa. In: PATERNIANI, E. \& VIEGAS, G.P., ed. Melhoramento e Produção do Milho. Campinas, Fundação Cargill, 1987. p. 137-208.

VENCOVSKY, R.; MIRANDA FILHO, J.B.; SOUZA JŪNIOR, C.L. Quantitative genetics and corn breeding in Brazil. In: INTERNATIONAL CONFERENCE ON QUANTITATIVE GENETICS, 2. Raleigh, 1987. Proceedings. Sunderland, 1988. p. 465-77.

VERDEIRO, A.; BERTOLINI, M.; GENTINETTA, E.; LORENZONI, C.; MAGGIORE, T.; MORRO, M. Recurrent selection for seed quality and agronomic traits in the D0o2 maịze variety. Maydica, Bergano, 33(3):201-11, 1988 .

WEBEL, O.D. \& LONNQUIST, J.H. An evaluation of modified ear-to-row selection in a population of corn (Zea mays L.) Crop Science, Madison, $7(6): 651-55,1967$

WEIGEL, P. Avaliação da produtividade e outros caracteres em duas populações (branca e amarela) de milho (Zea mays L.) separadas do dentado composto. Piracicaba, 1978. 176p. (Mestrado - Escola Superior de Agricultura "Luiz de Queiroz"/USP). 
WESSEL-BEAVER, L.; LAMBERT, R.J.; DUDLEY, J.W. Genetic variability and correlations in a modified endosperm texture opaque-2 maize population. Crop Science, Madison, 25(1):129-32, 1985.

WIDSTROM, N.W. \& JELLUM, M.D. Inheritance of kernel fatty acid composition among six maize inbreds. Crop Science, Madison, 15(1):44-6, 1975.

WIDSTROM, N.W. \& JELLUM, M.D. Chromossomal location of genes controlling oleic and linoleic composition in the germ oil of two maize inbreds. Crop Science, Madison, 24(6):1113-5, 1984.

WINTER, F.L. The mean and variability as affect by continuous selection for composition in corn. In: DUDLEY, J.W. ed. Seventy generations of selection for oil and protein in maize, Madison, Crop Science Society of America, 1974. p.95-119.

WOODWORT, C.M.; LENG, E.R.; JUGENHEIMER, R.W. Fifty. generations of selection for protein and oil in corn. Agronomy Journal,' Madison, $44(2): 60-5,1952$

ZANOTTO, D.M. Variabilidade genética e endogamia em duas populações de milho (Zea mays L.) contrastantes para teor de óleo. Piracicaba, 1986. 62p. (Mestrado - Escola Superior de Agricultura "Luiz de Queiroz"/USP).

ZIMBACK, L. Estimação de parâmetros genéticos e fenotípicos em uma variedade de milho dentado bráquítico opaco (Zea mays L.). Piracicaba, 1985. 169p. (Mestrado - Escola Superior de Agricultura "Luiz de Queiroz"/USP). 
ZUBER, M.S. Relative efficiency of incomplete block designs corn uniformity trial data. Agronomy Journal, Madison, 34(1):30-47, 1942. 
TABELAS DE RESULTADOS 


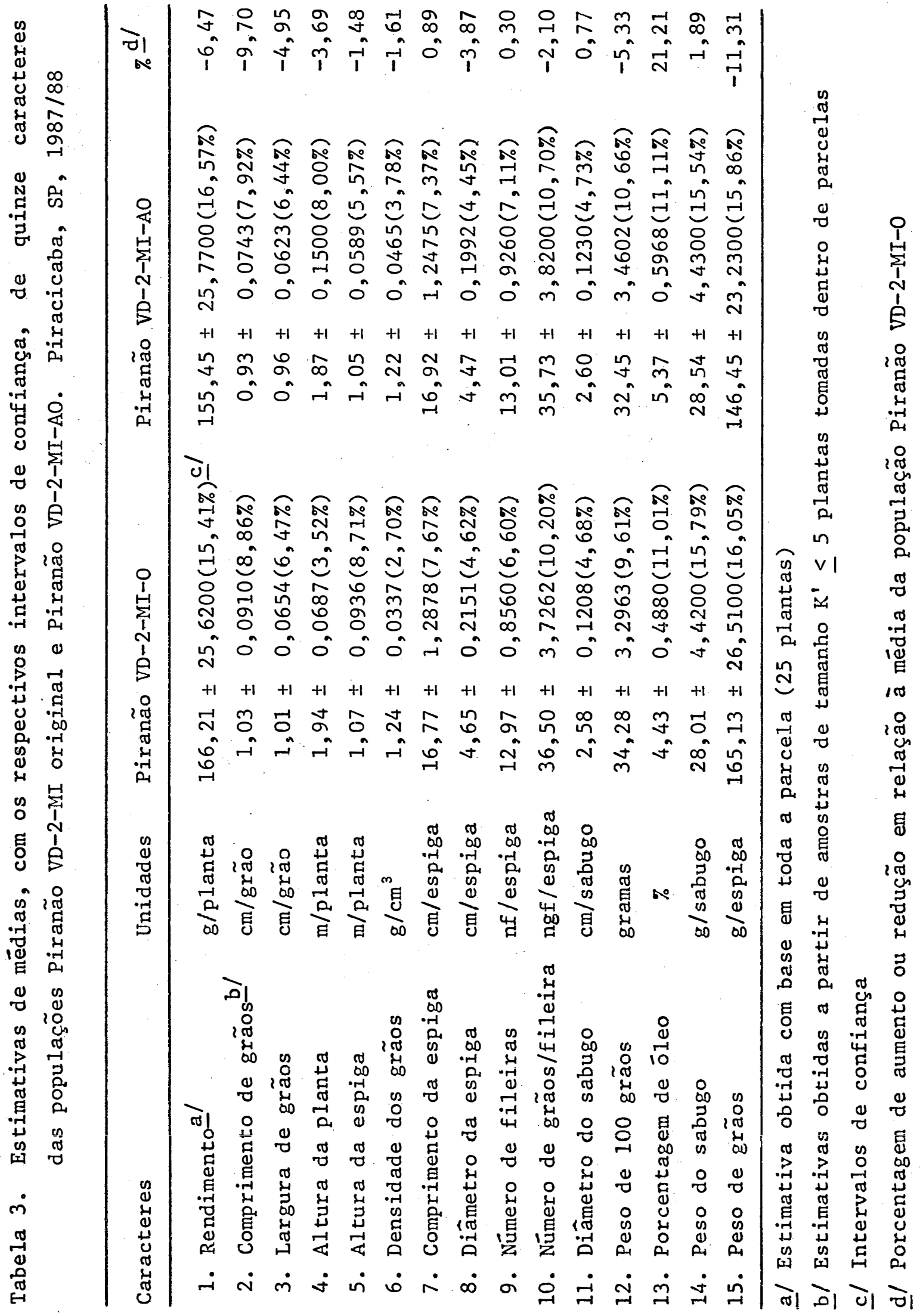




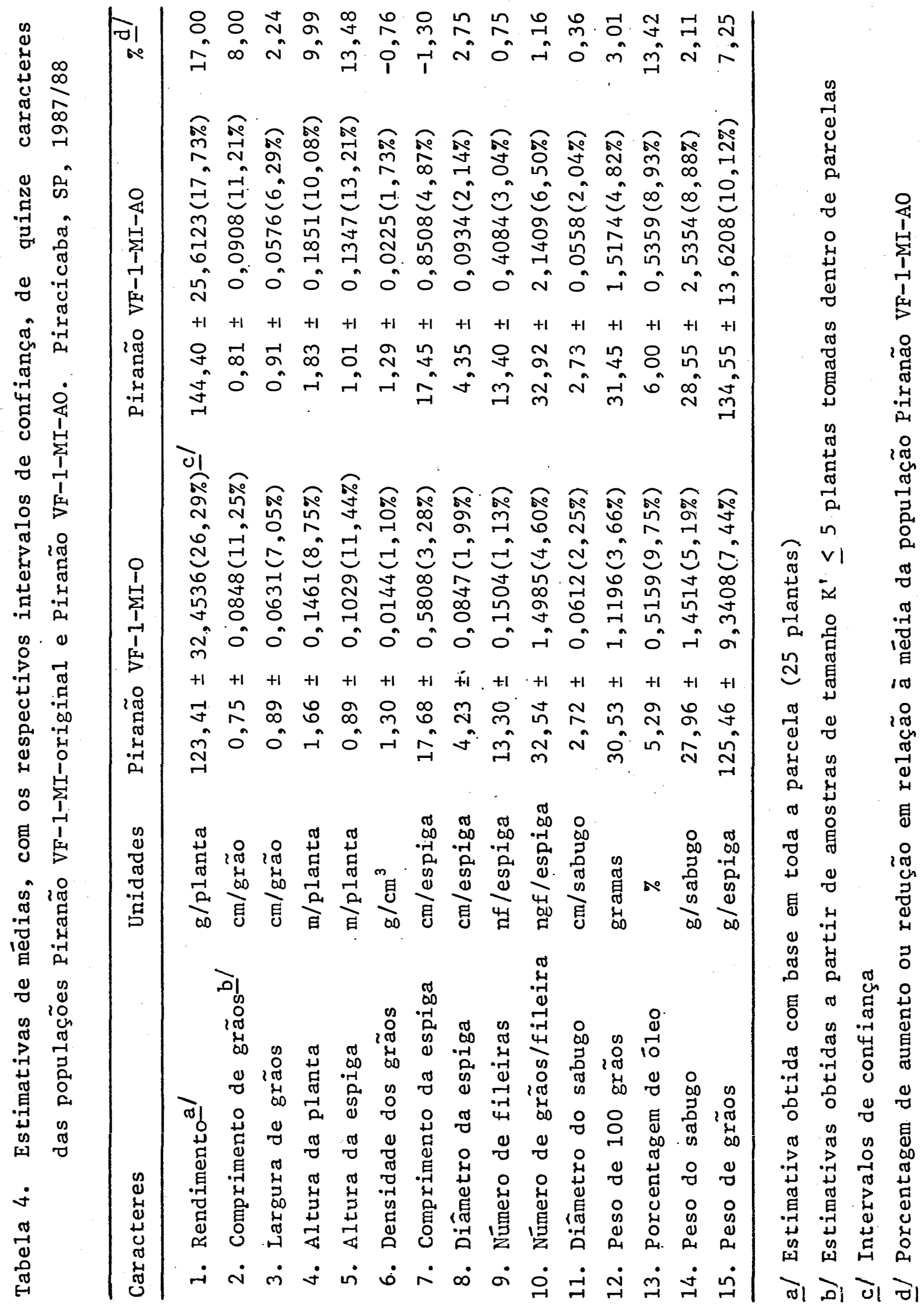




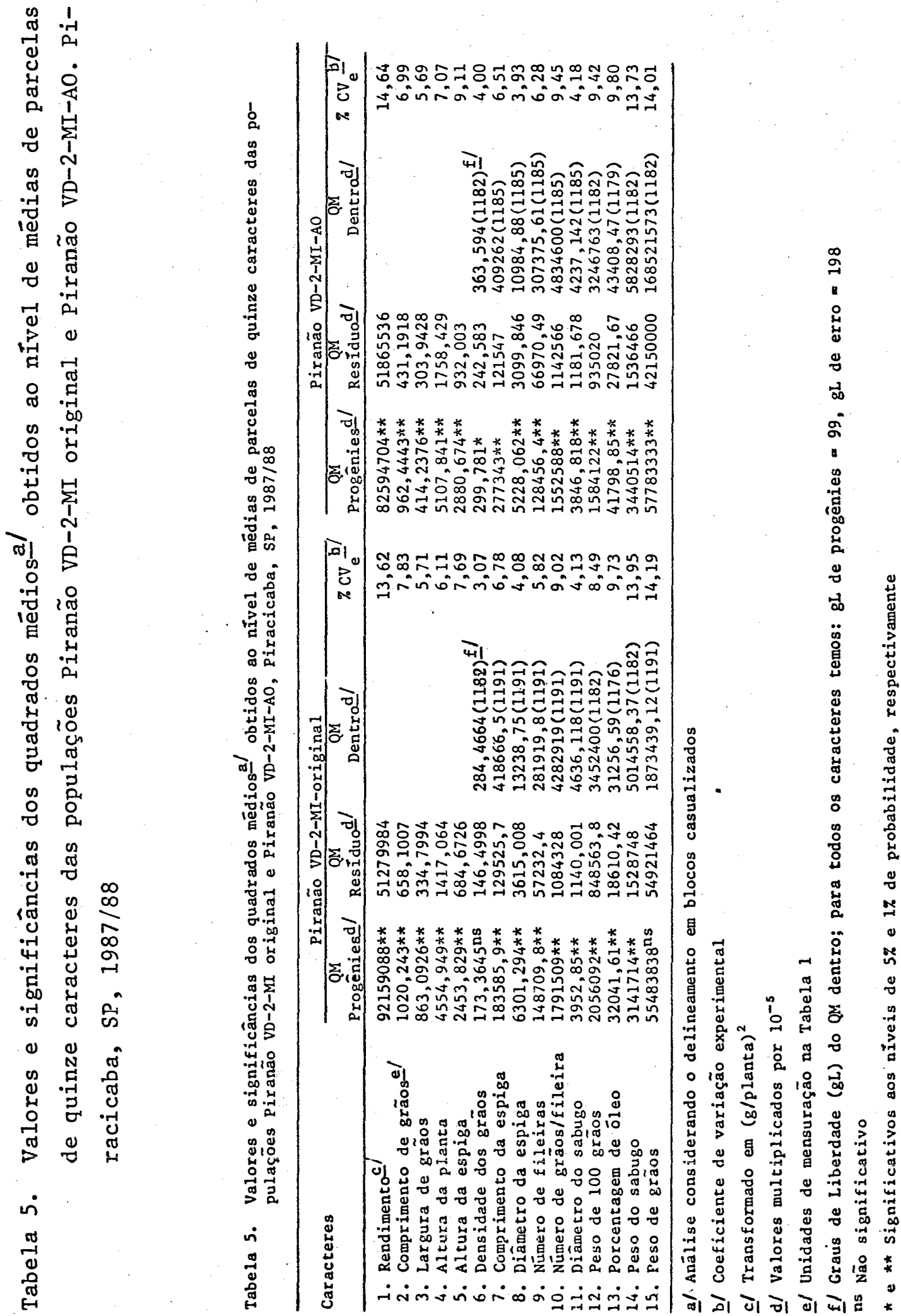



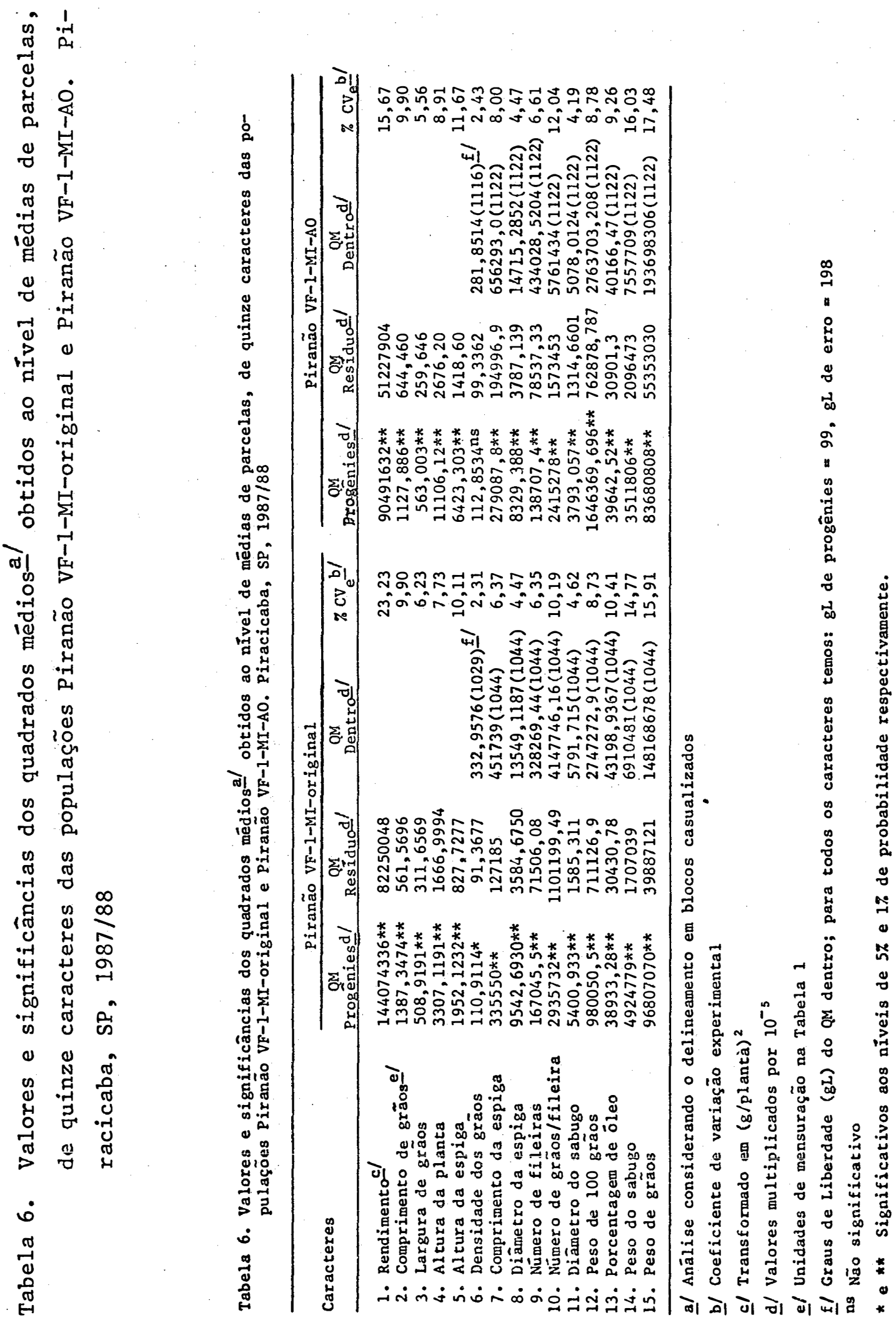


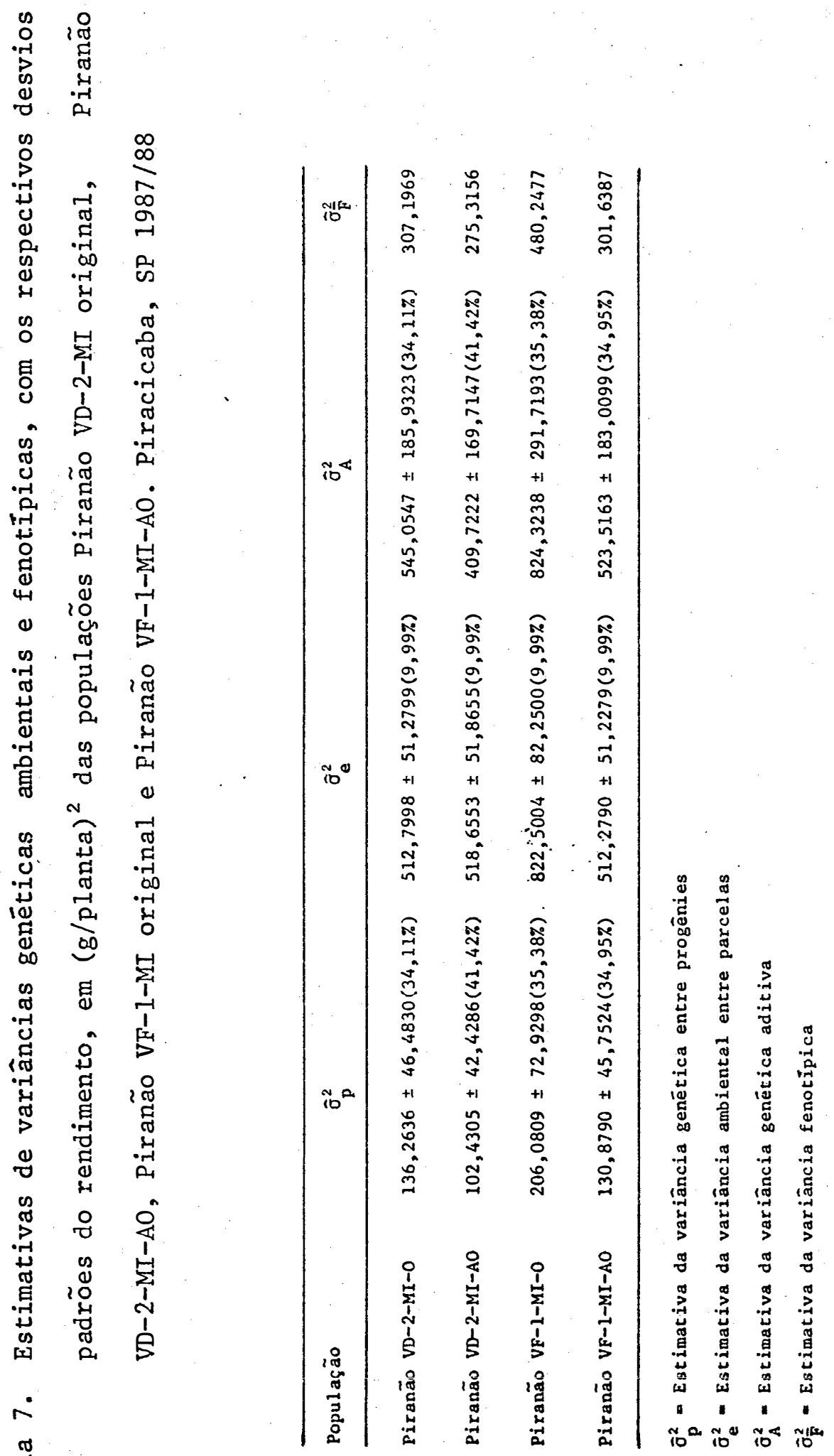




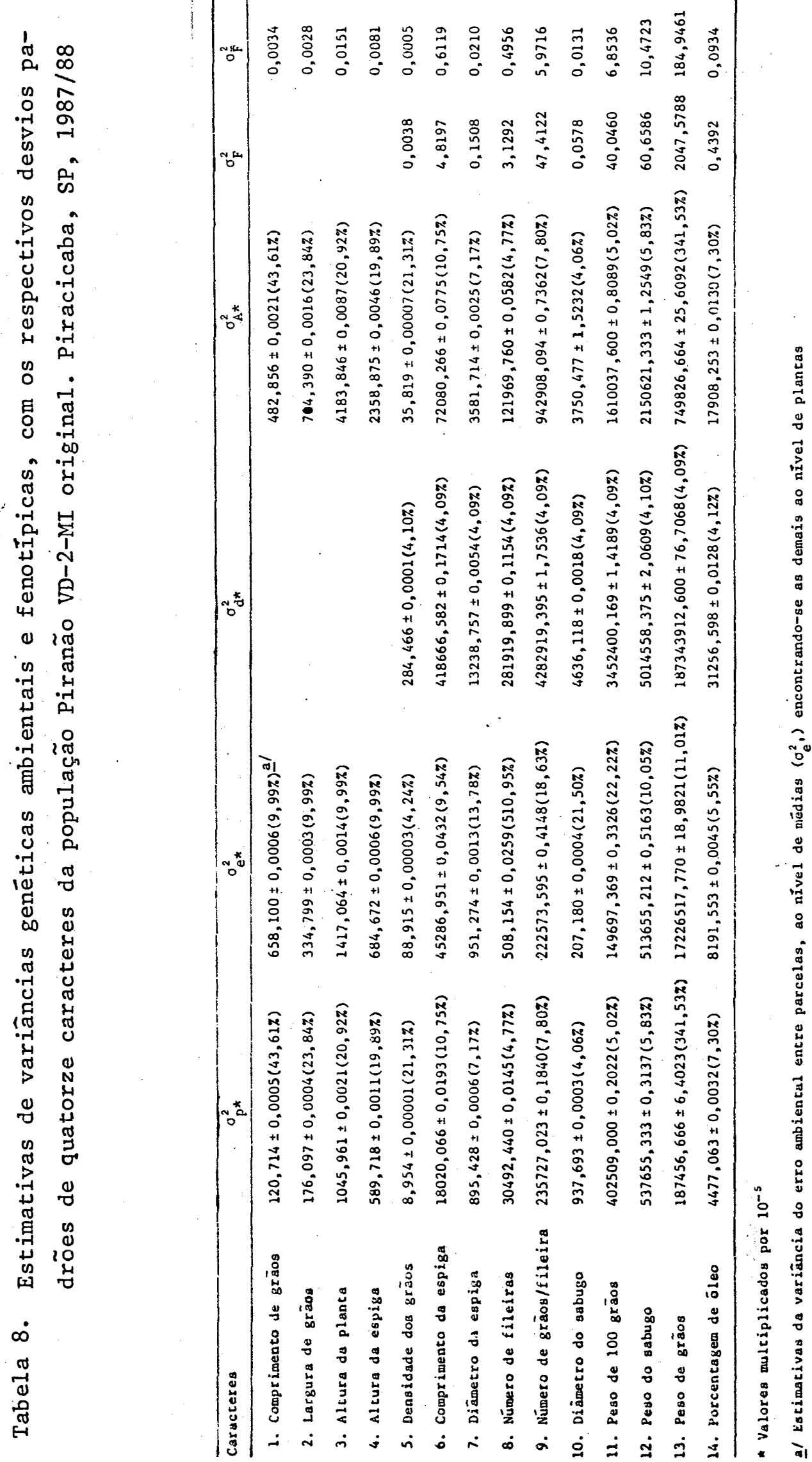




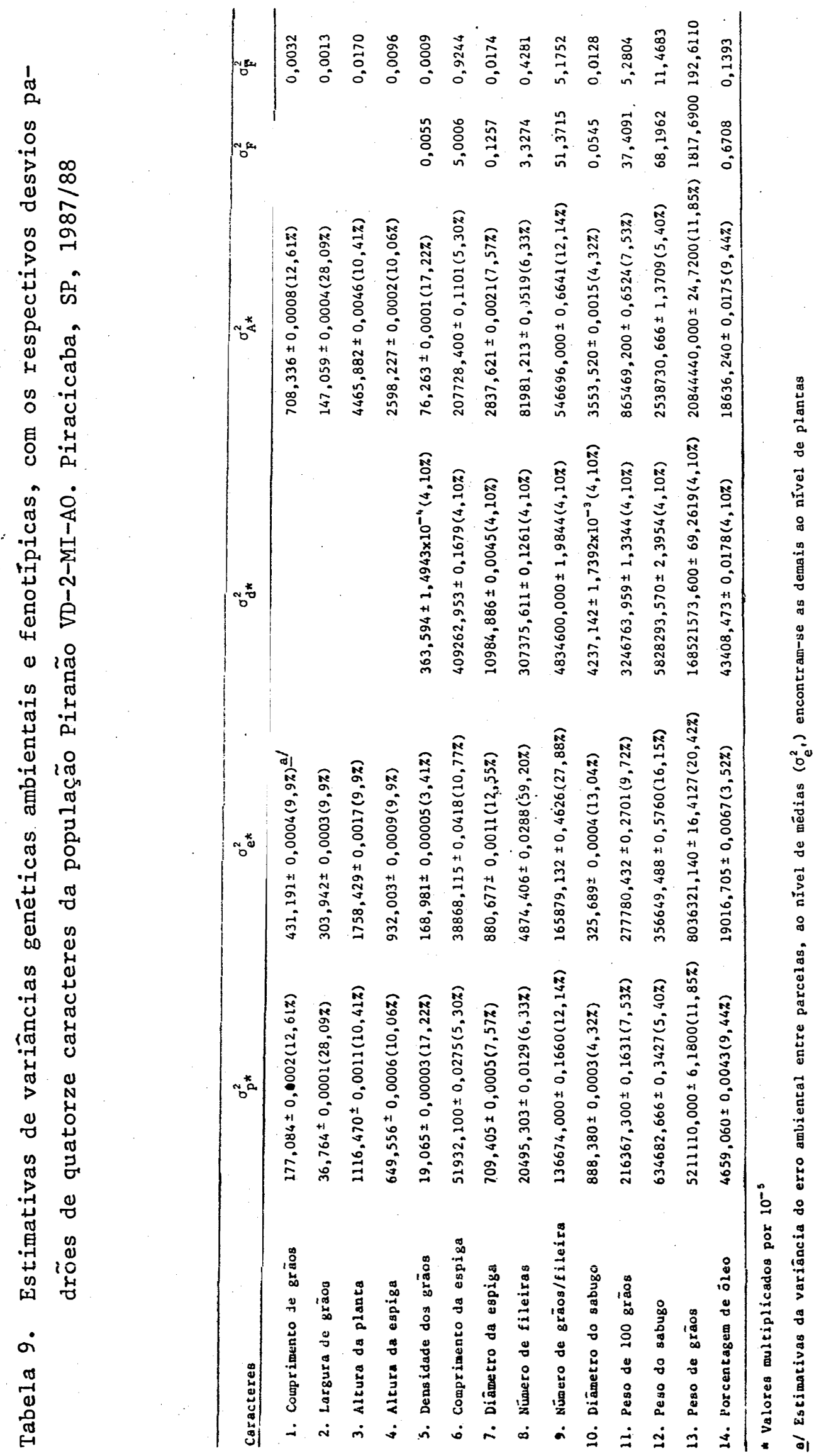




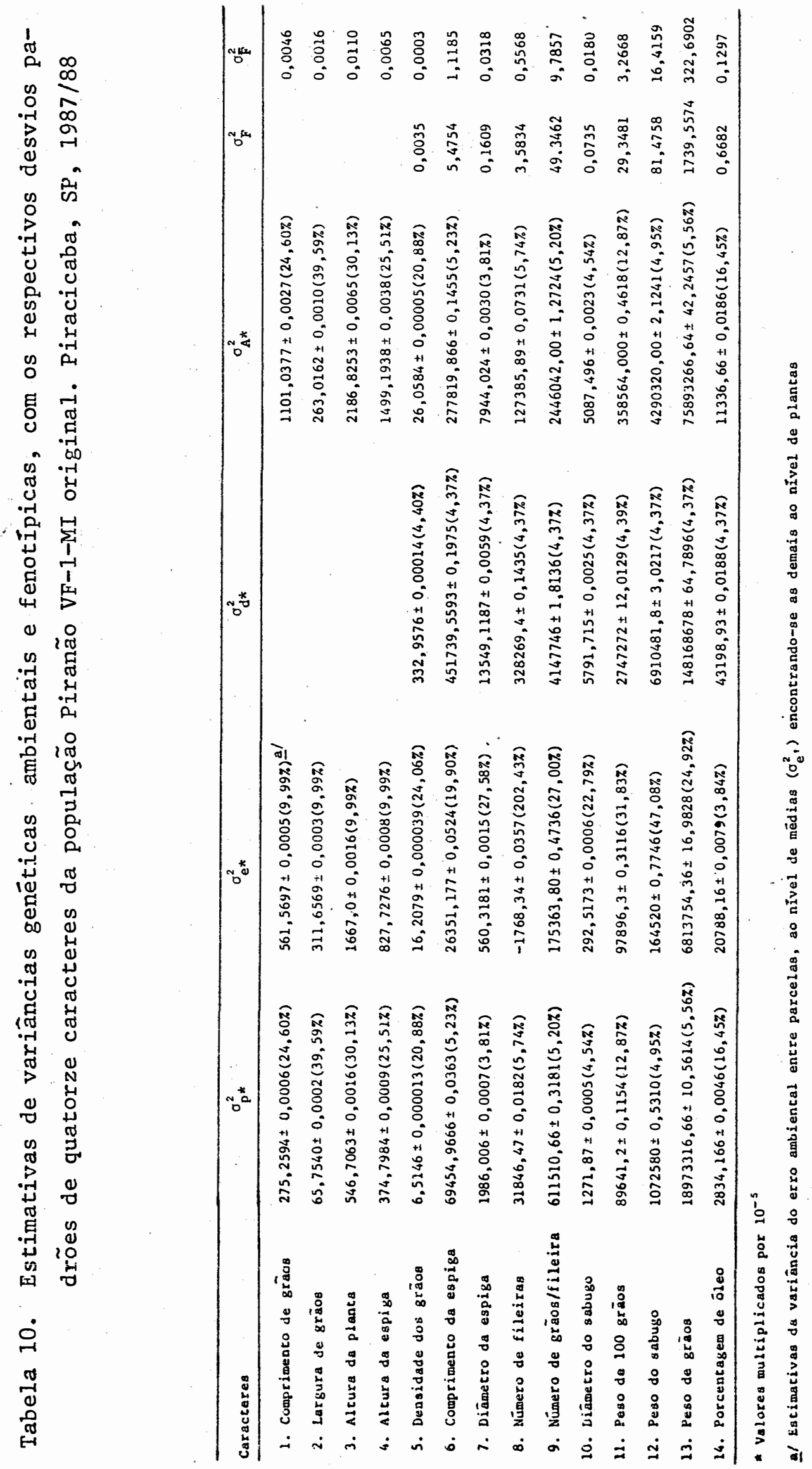




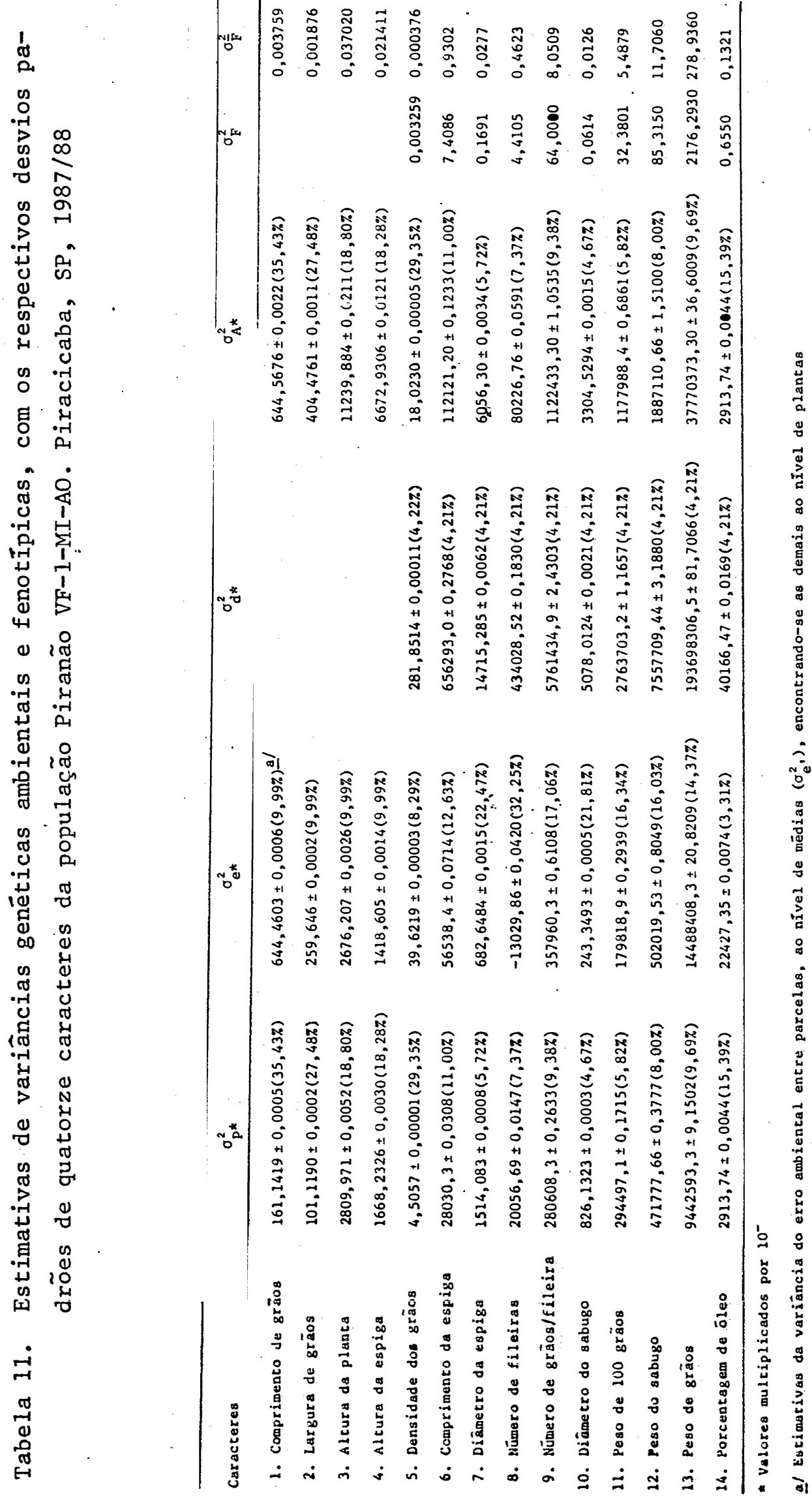




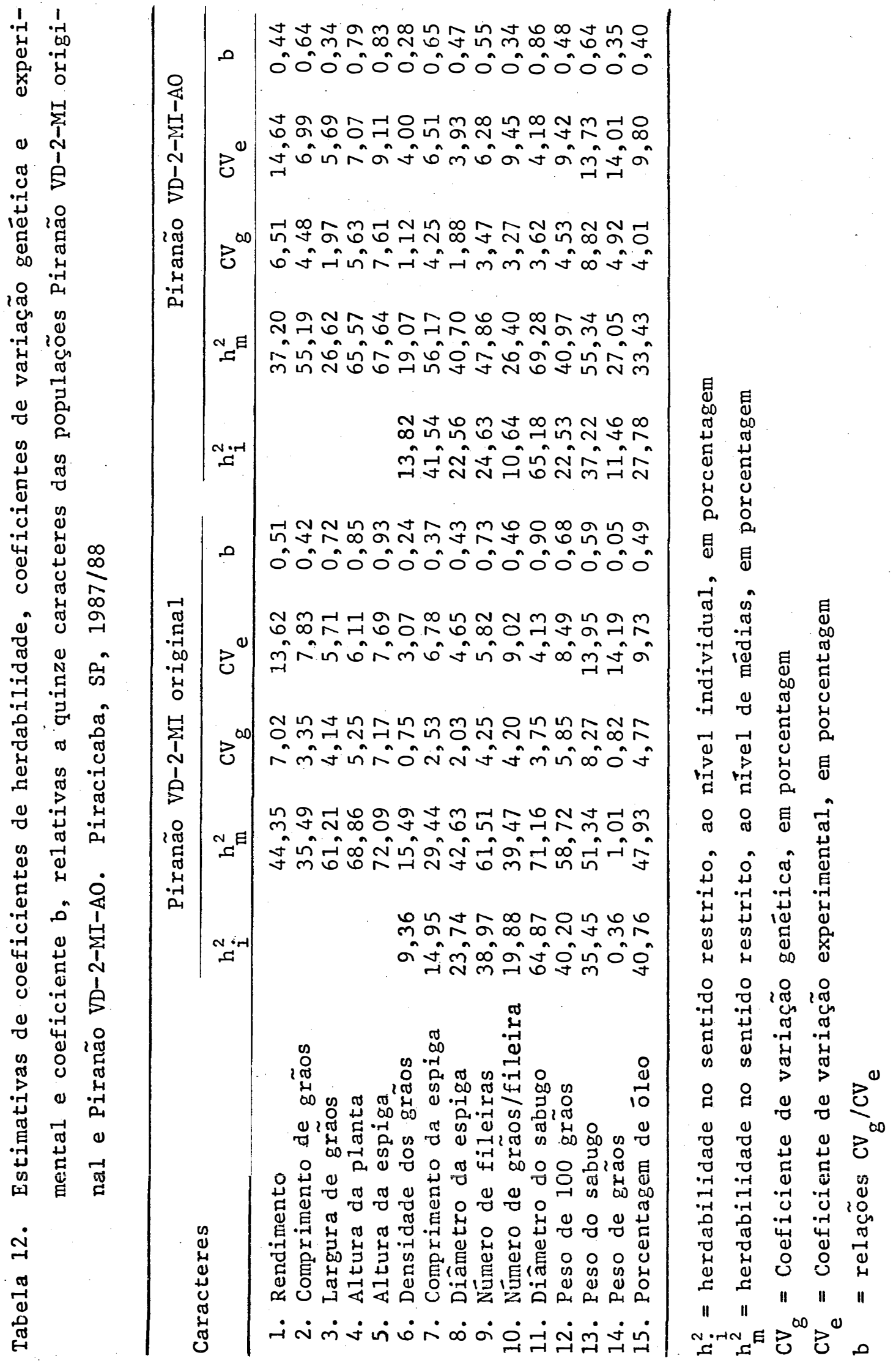




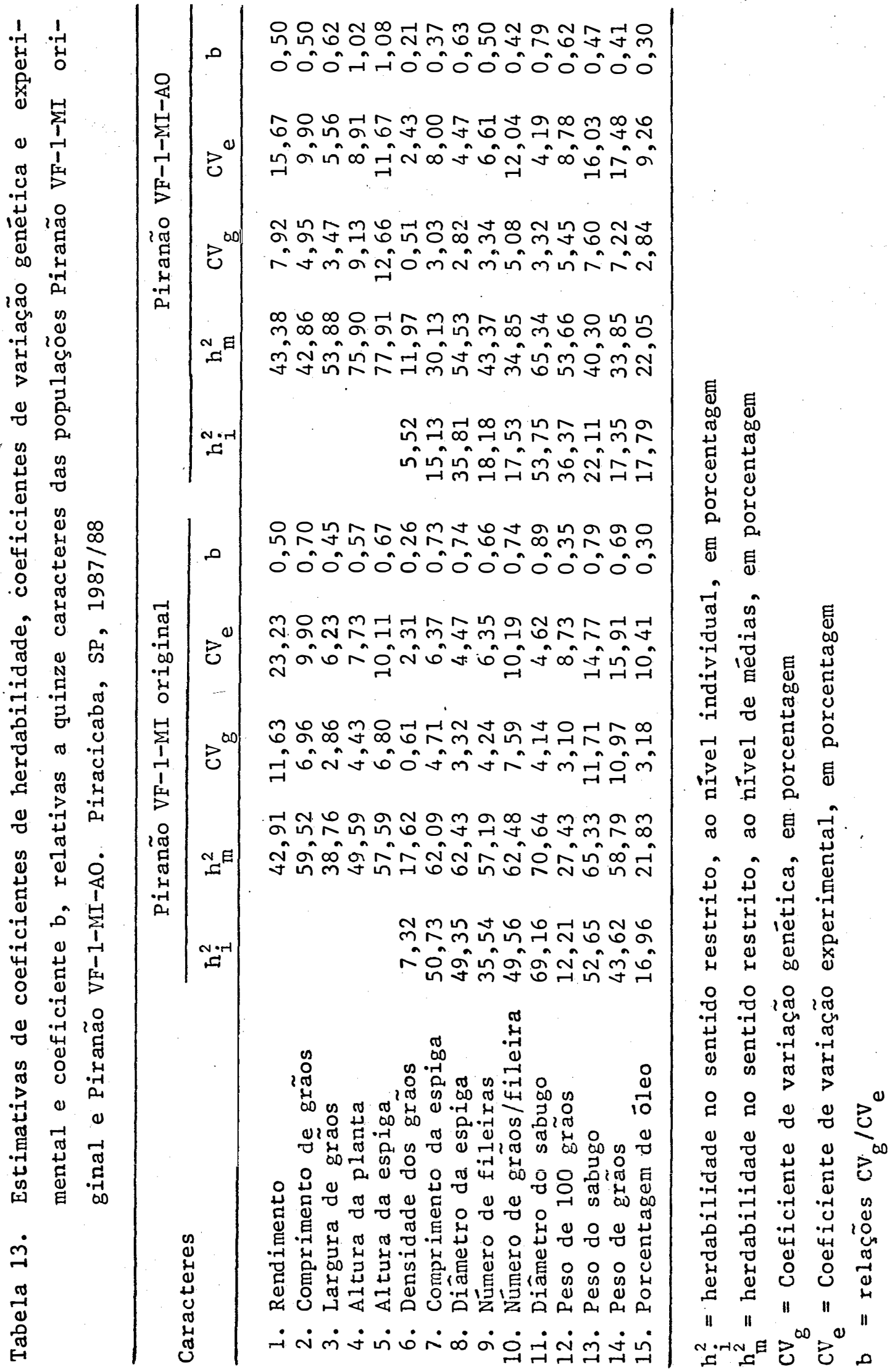




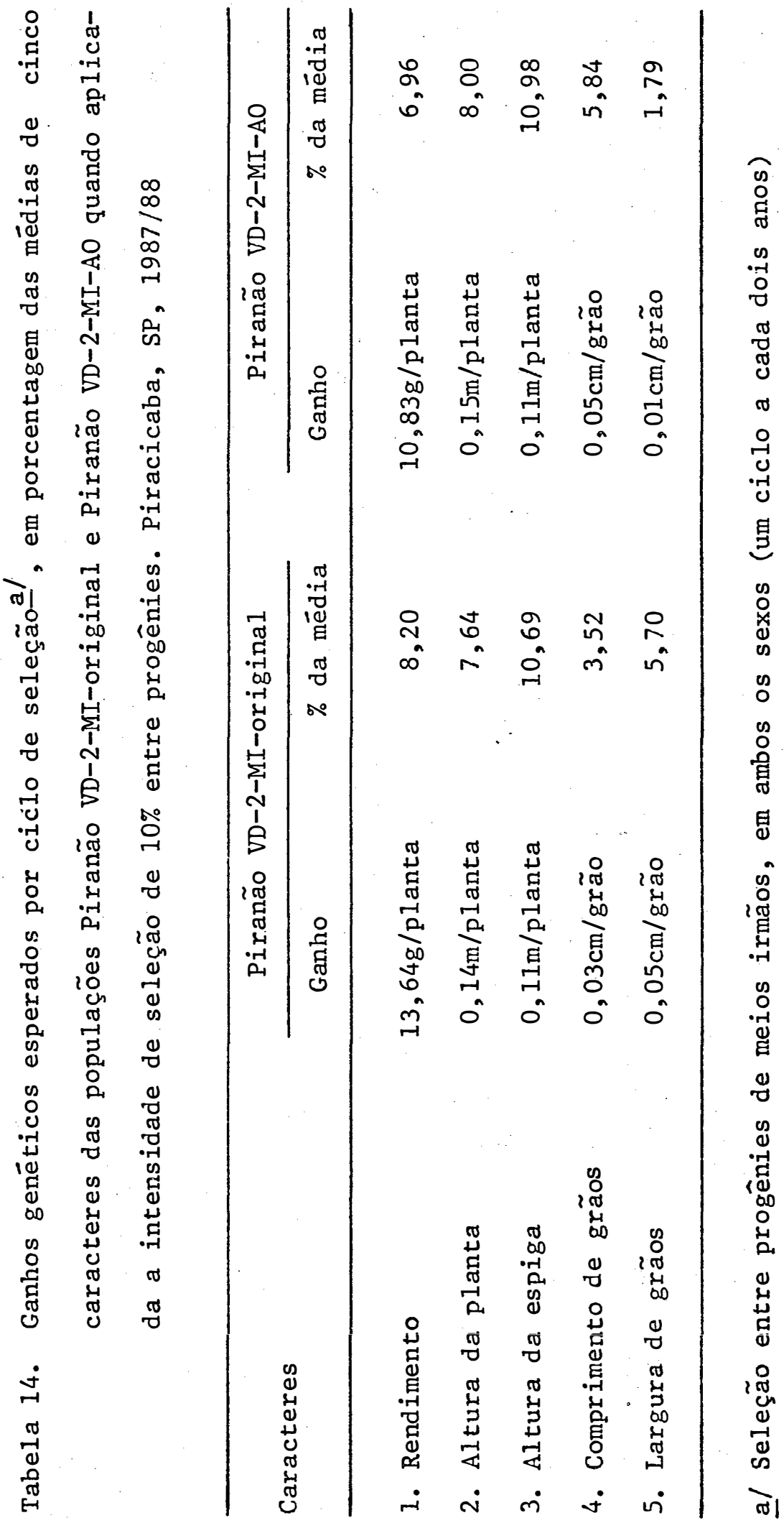




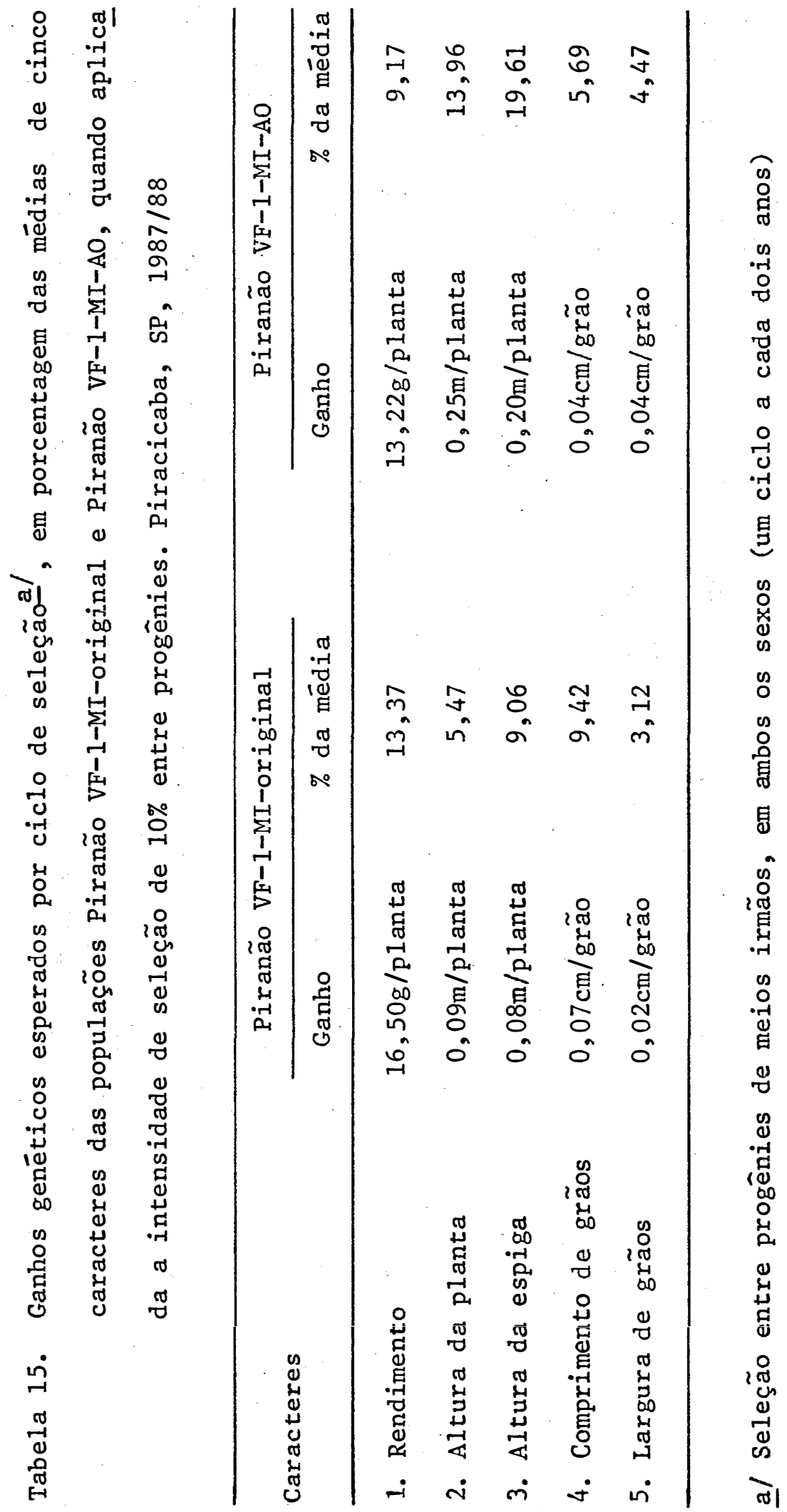




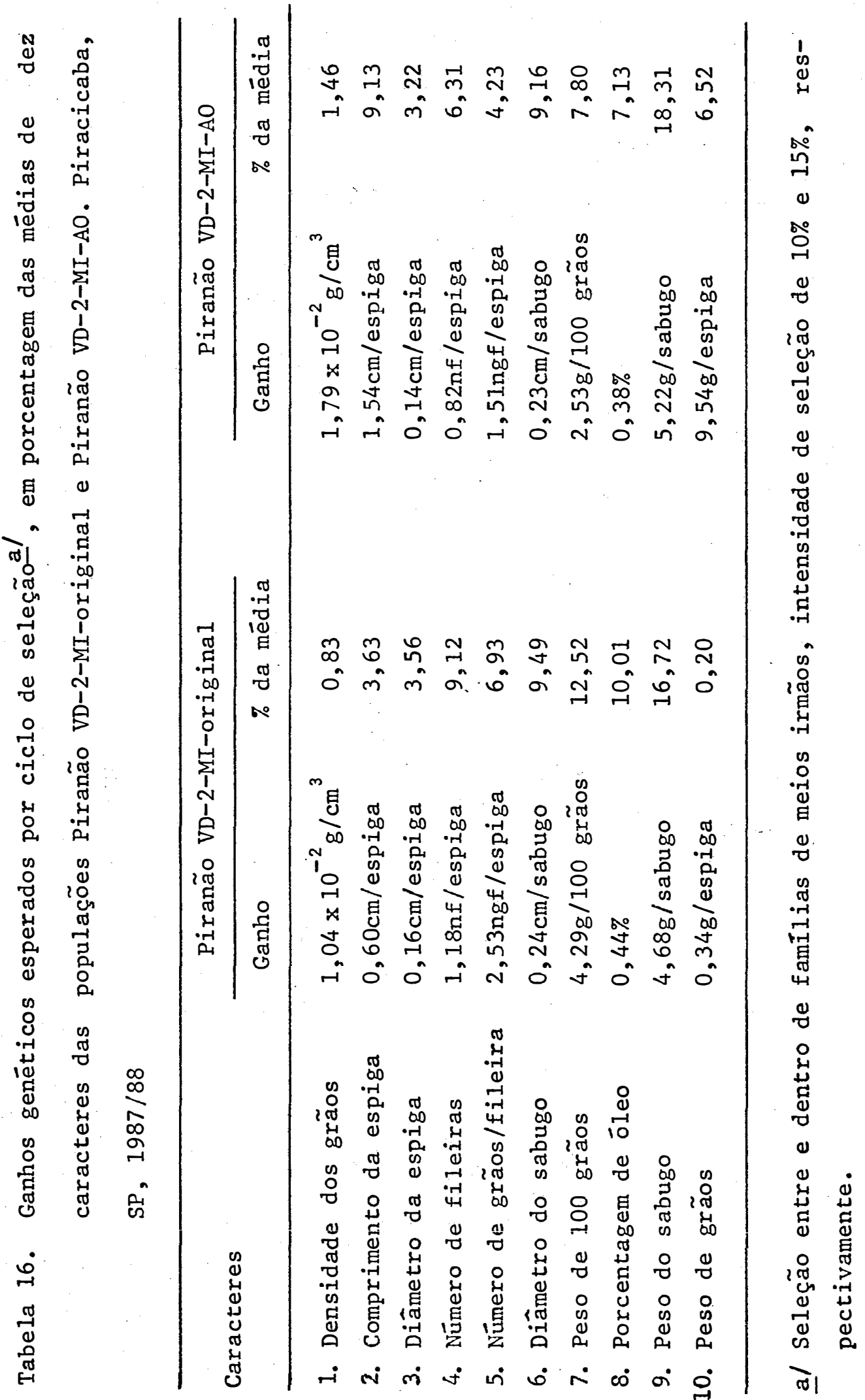




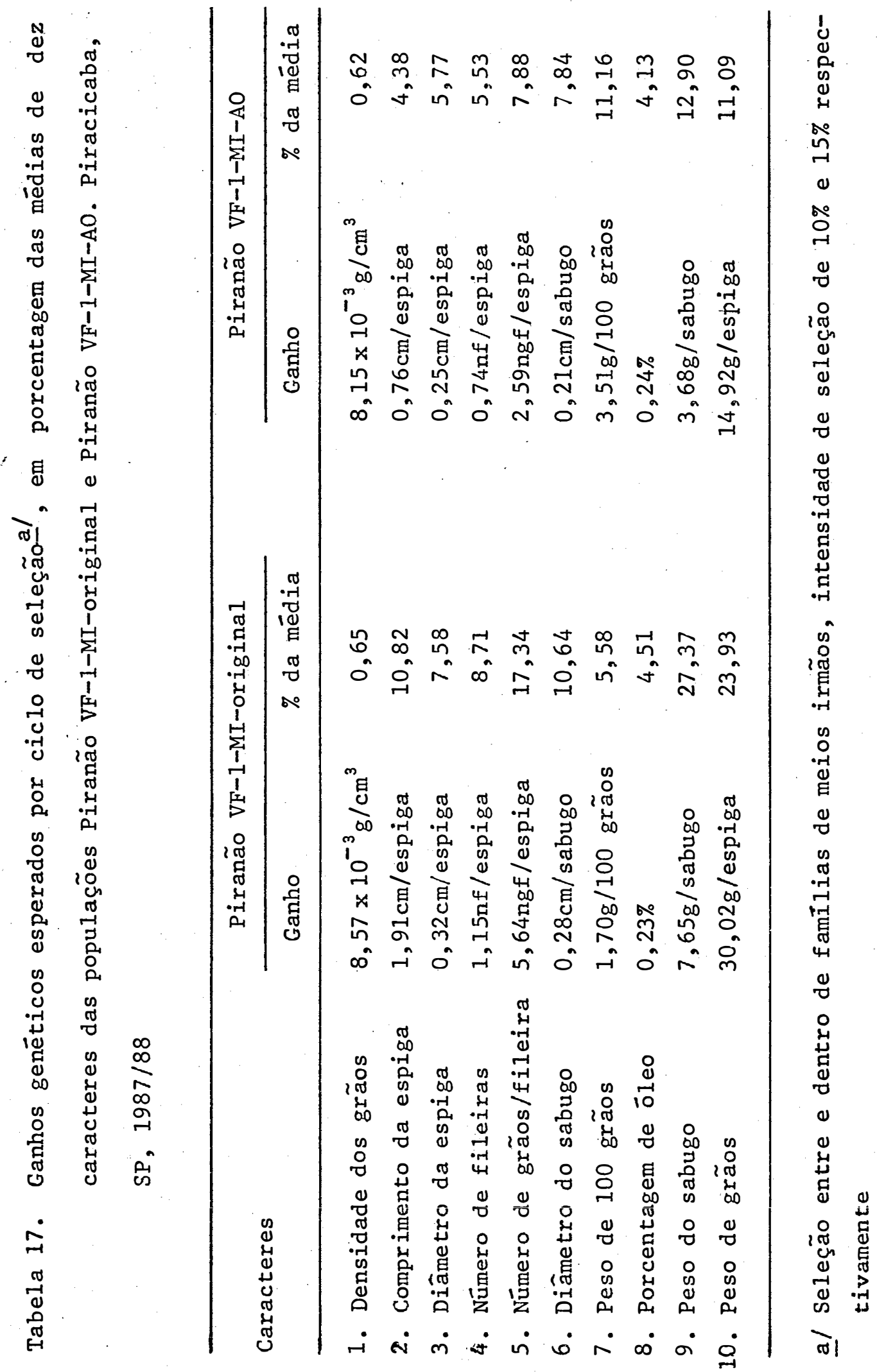




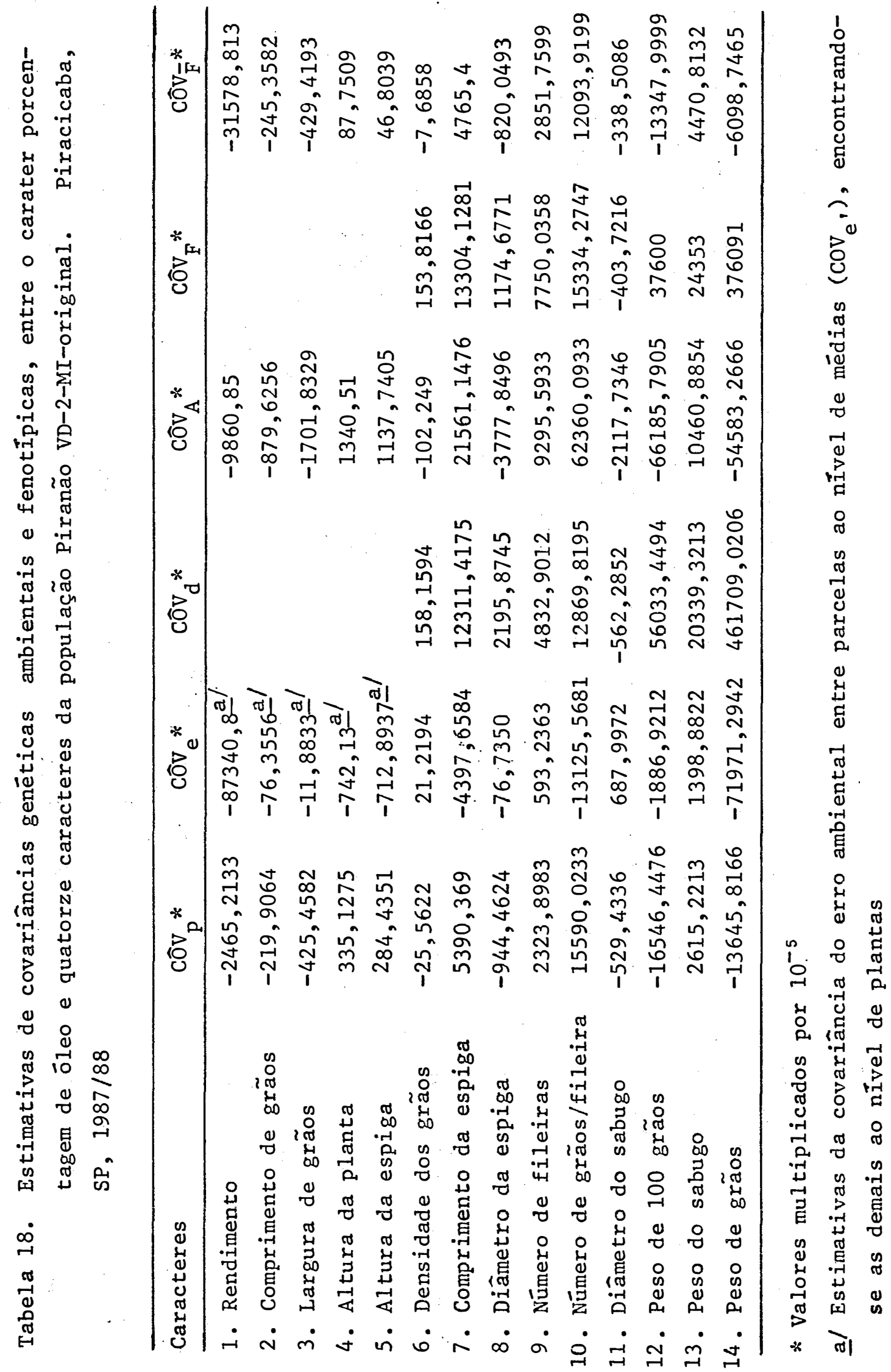




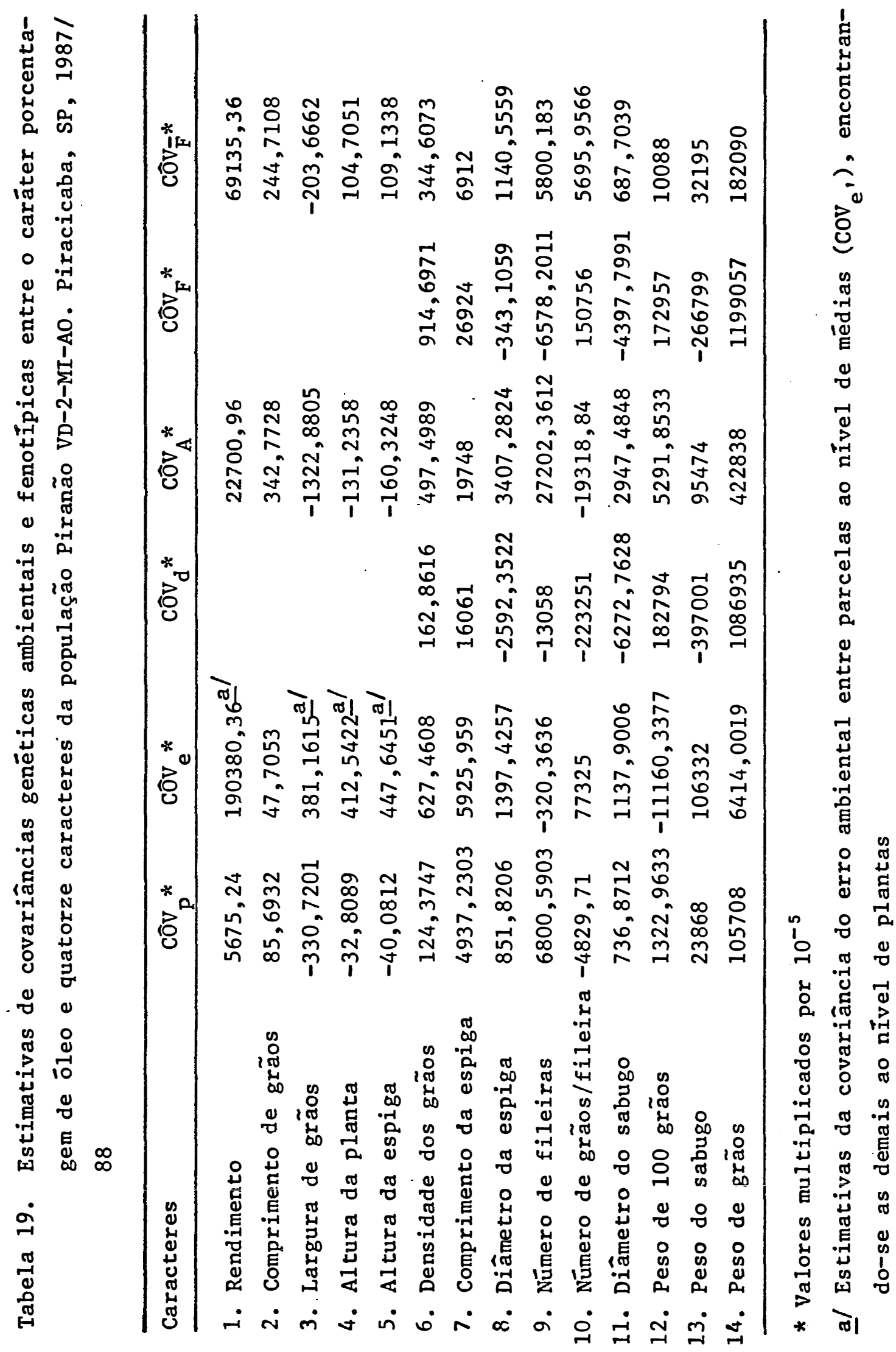




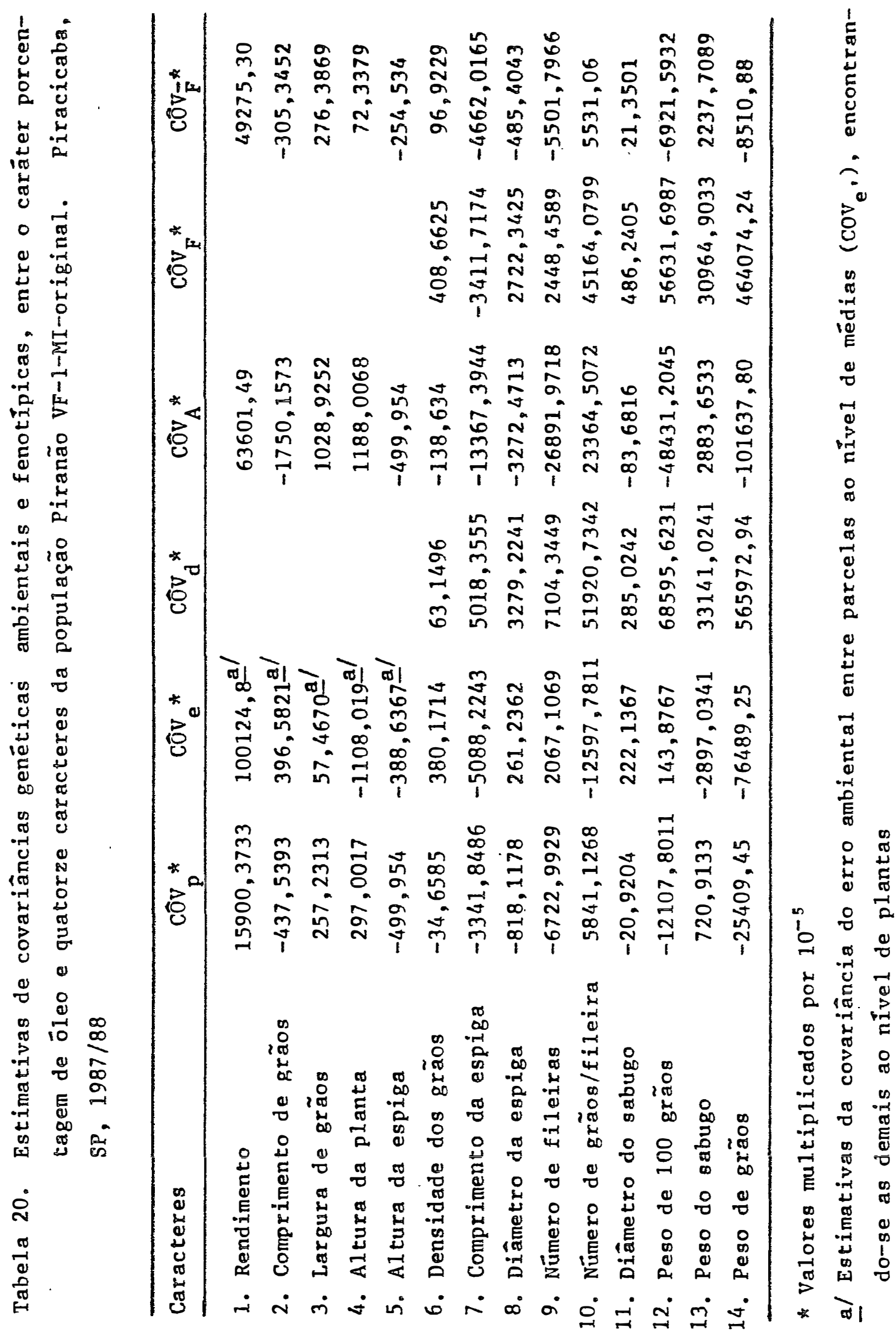




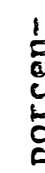

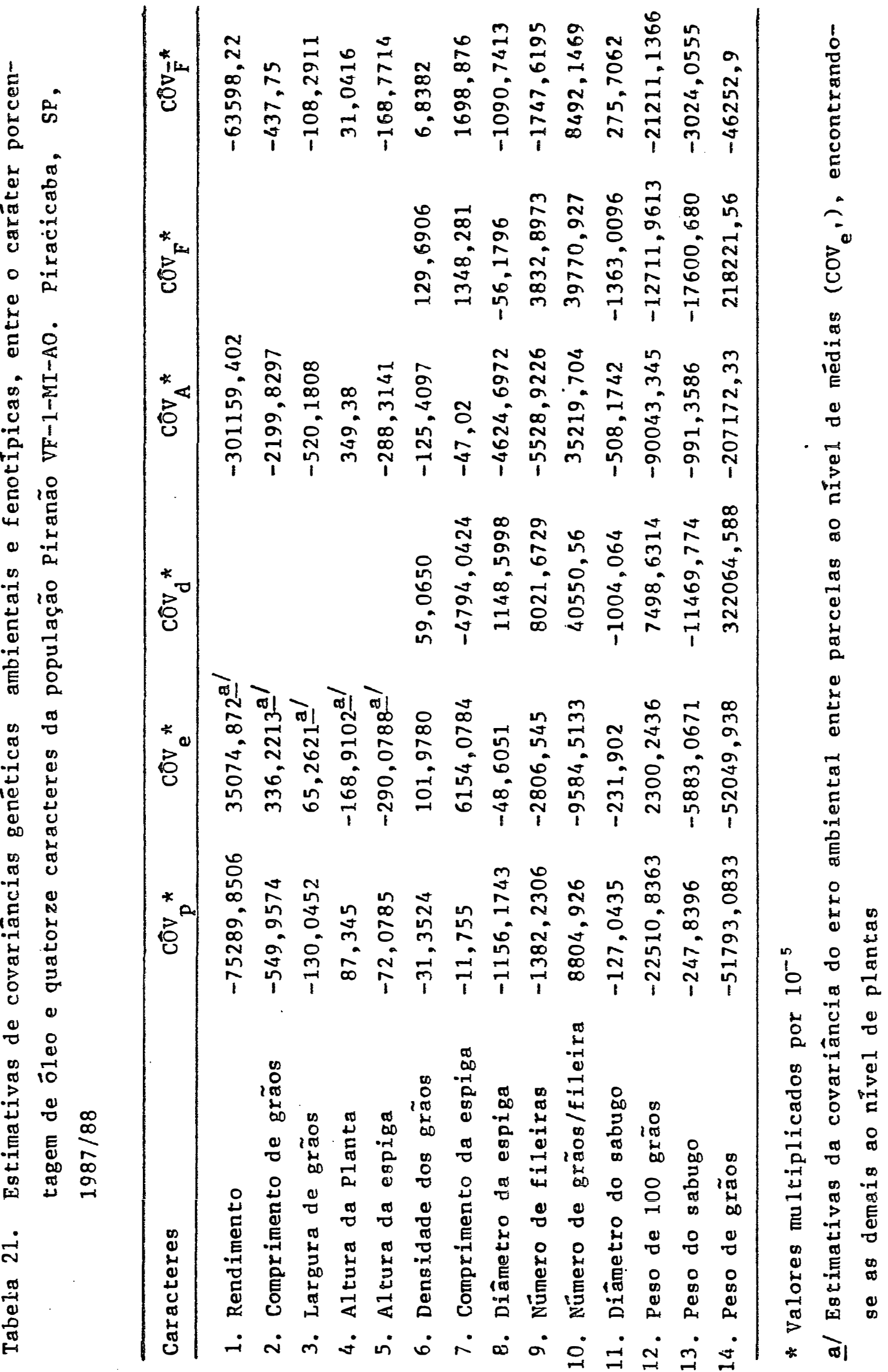




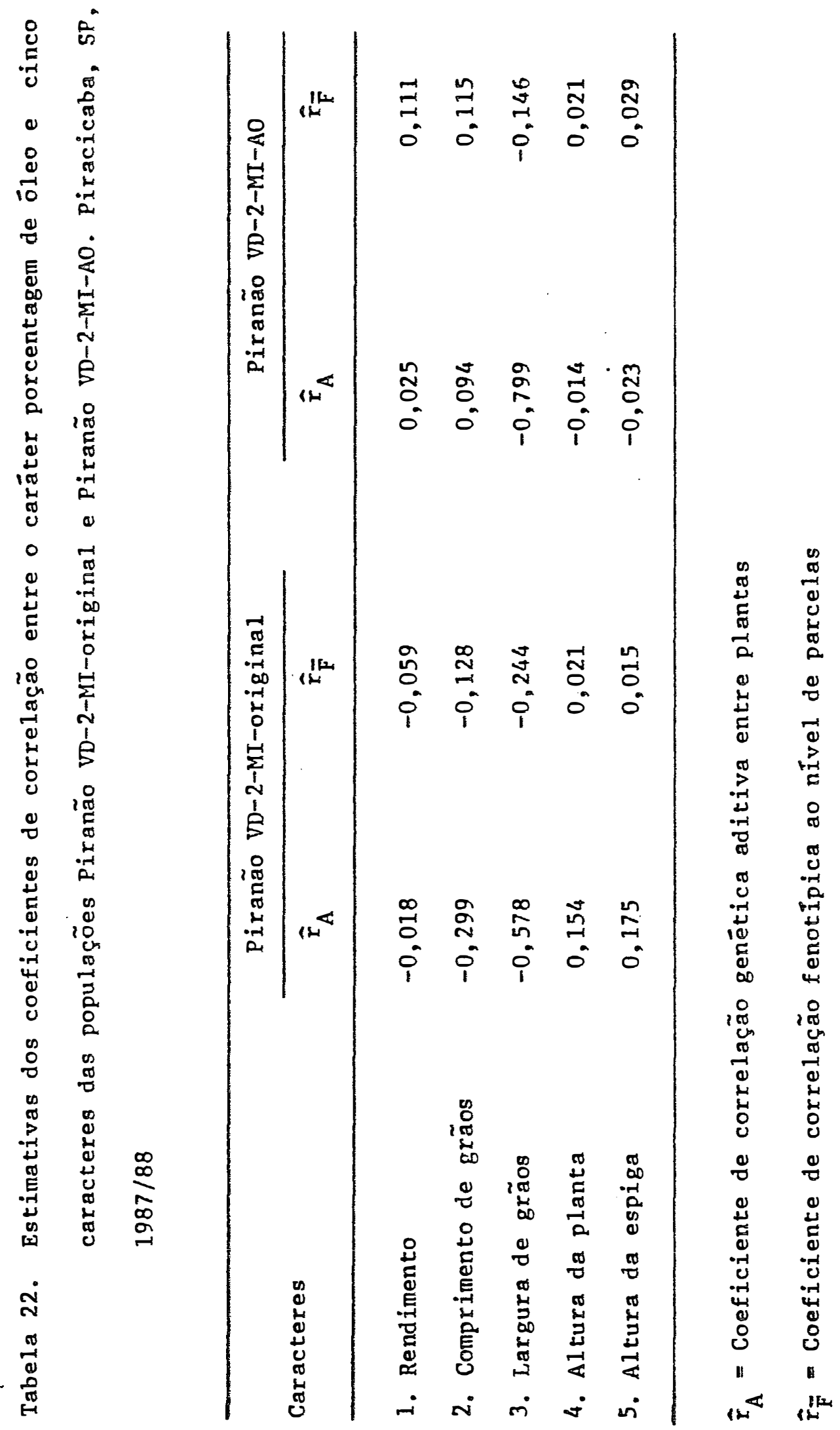




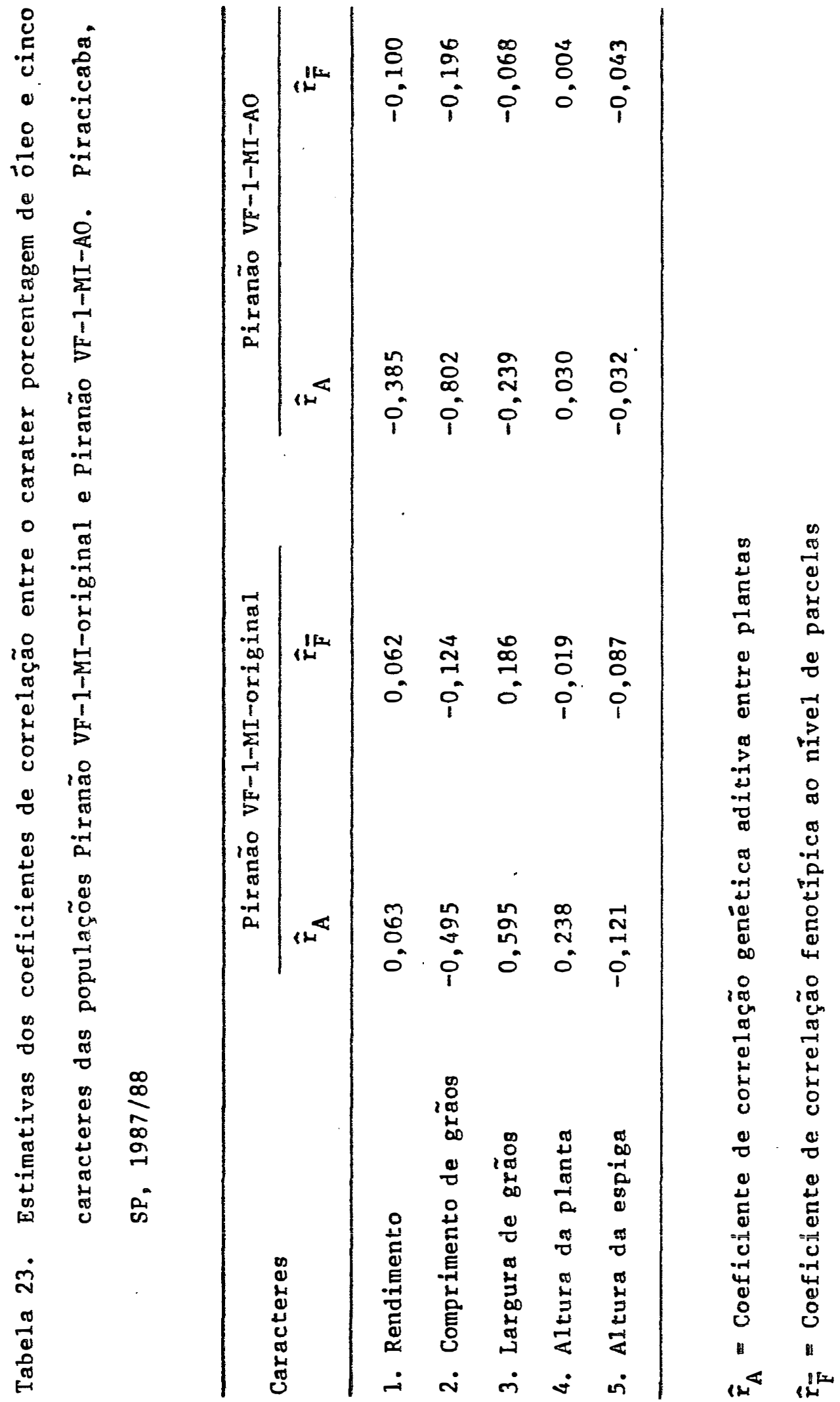




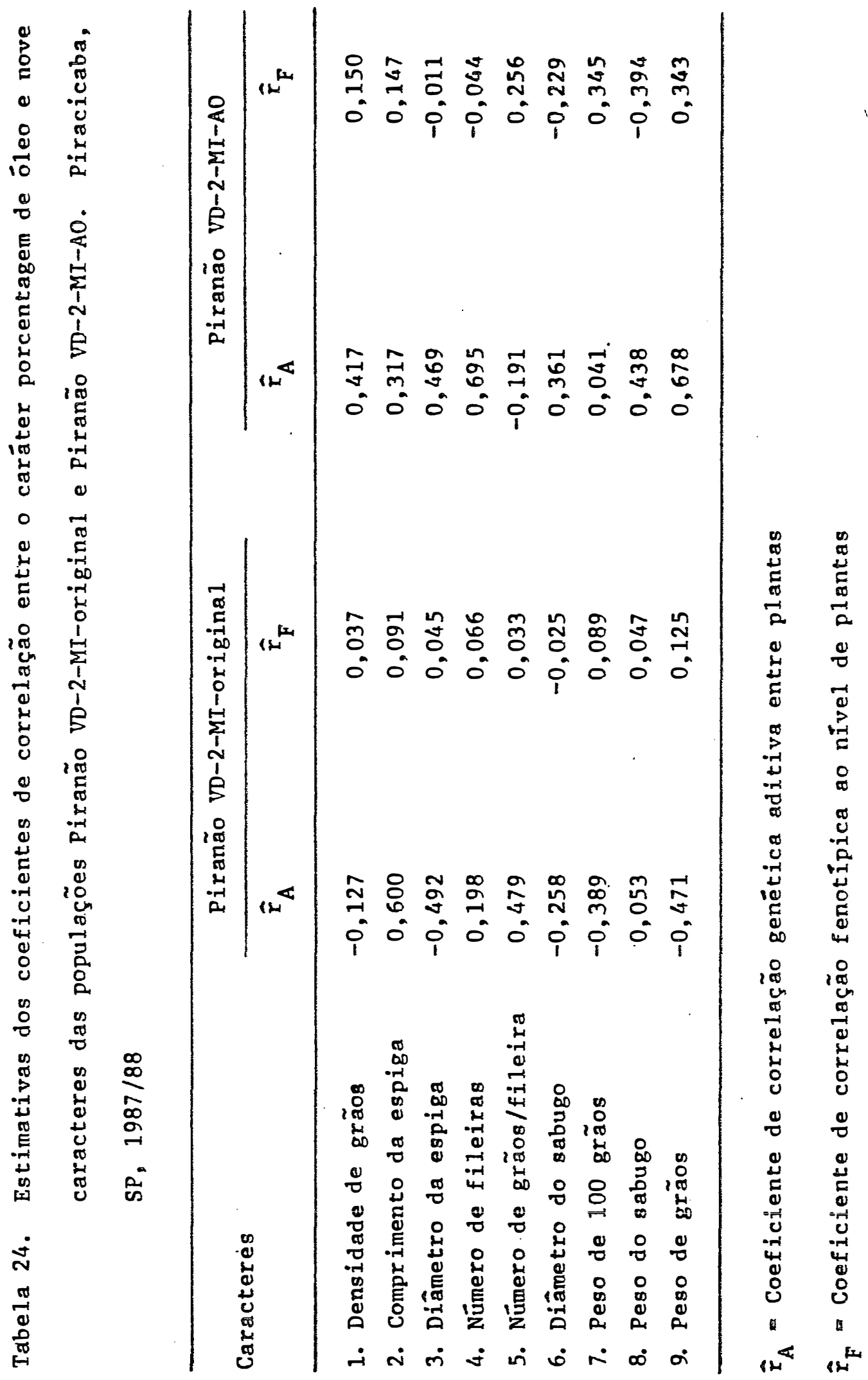




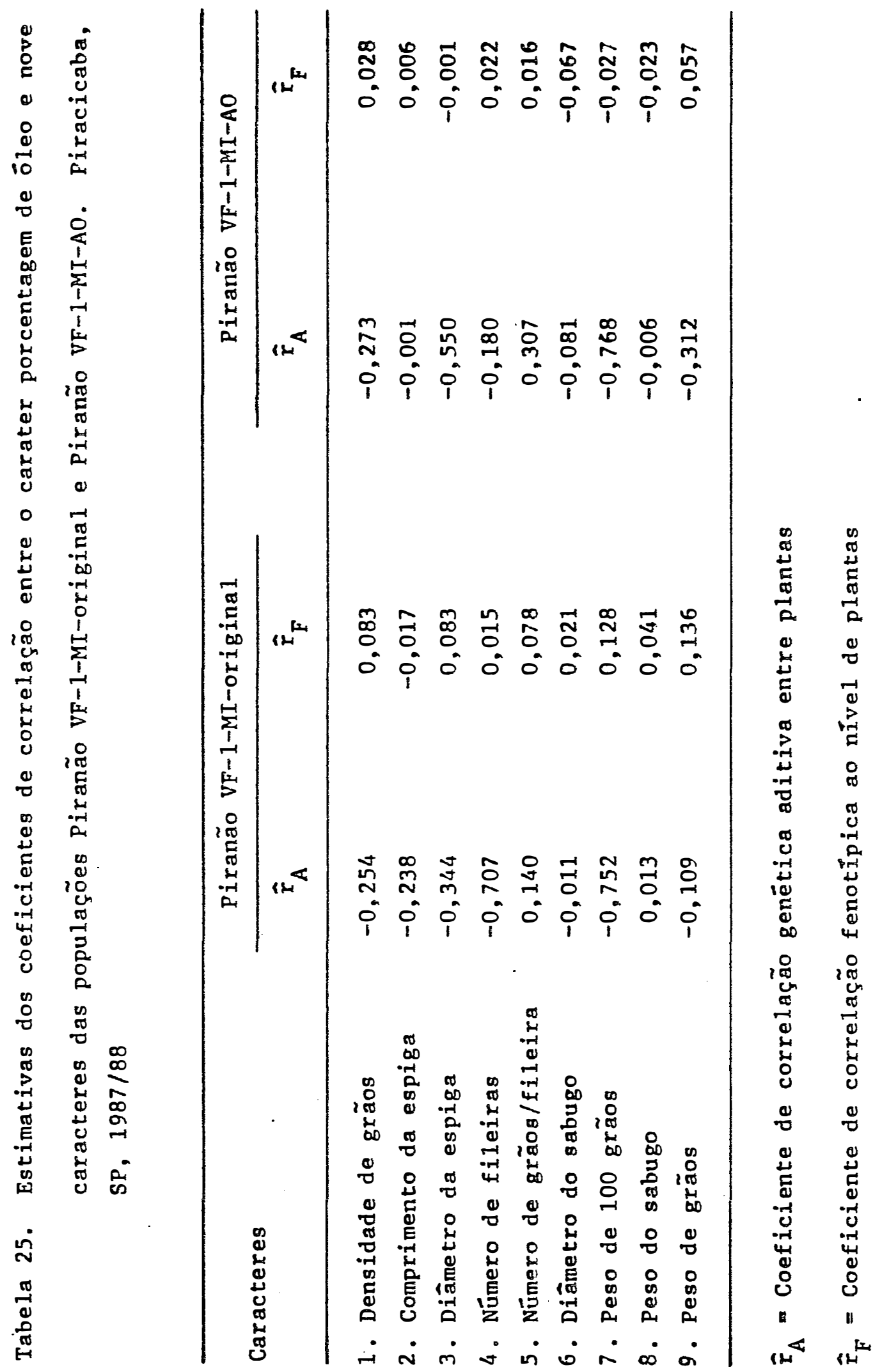




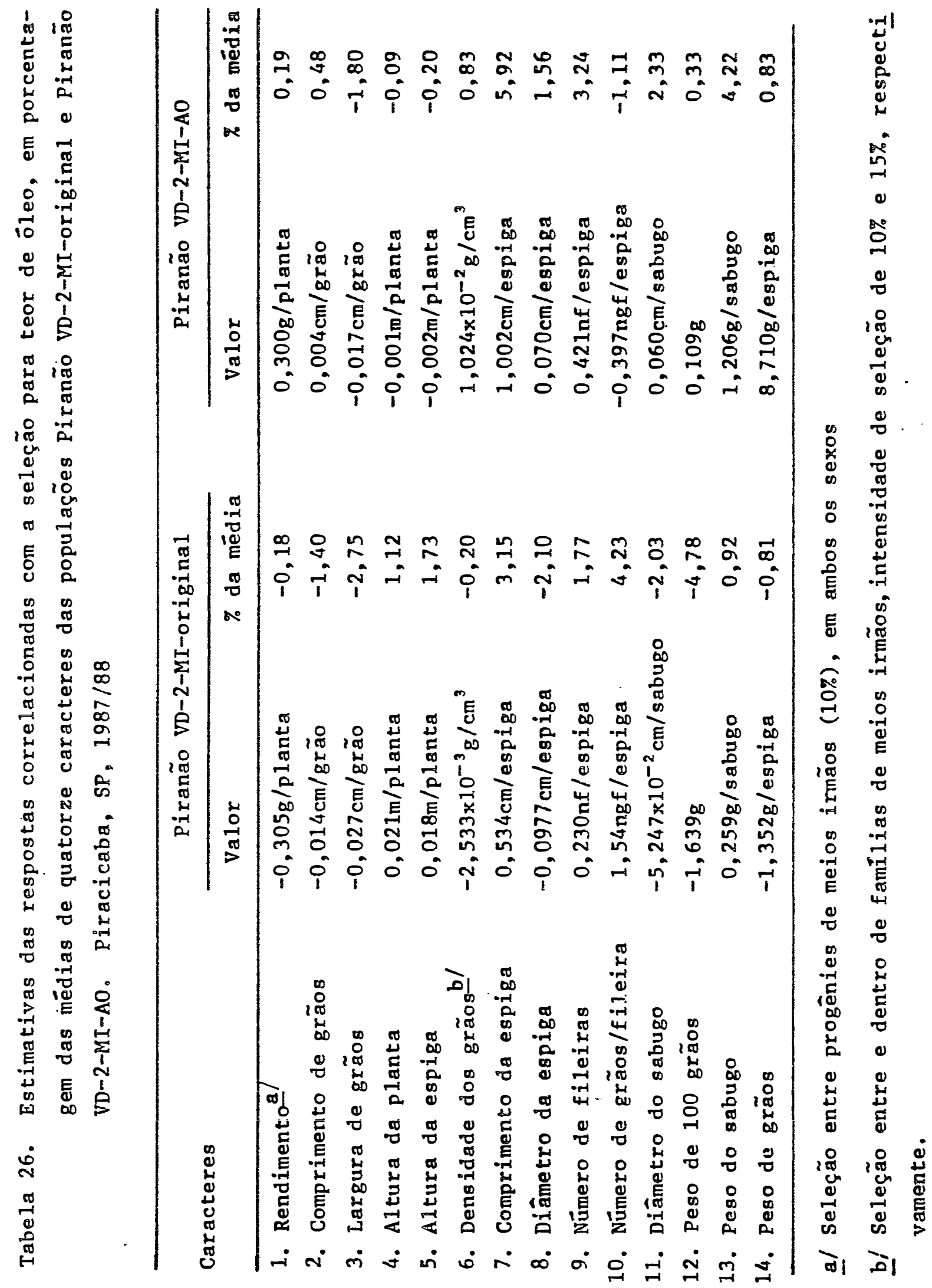




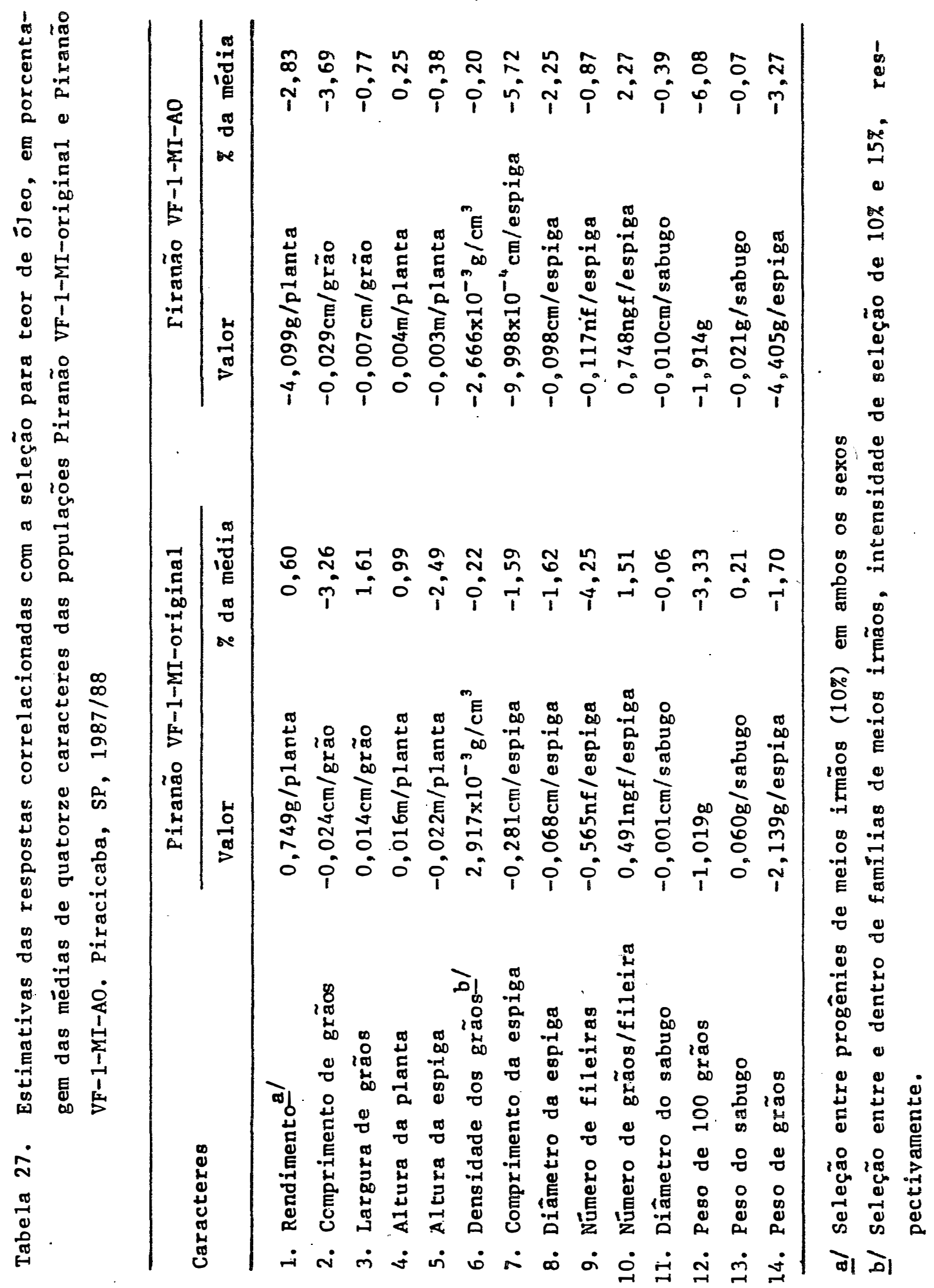

